(1) Nordic Council of Ministers

\title{
Working environment and work retention
}

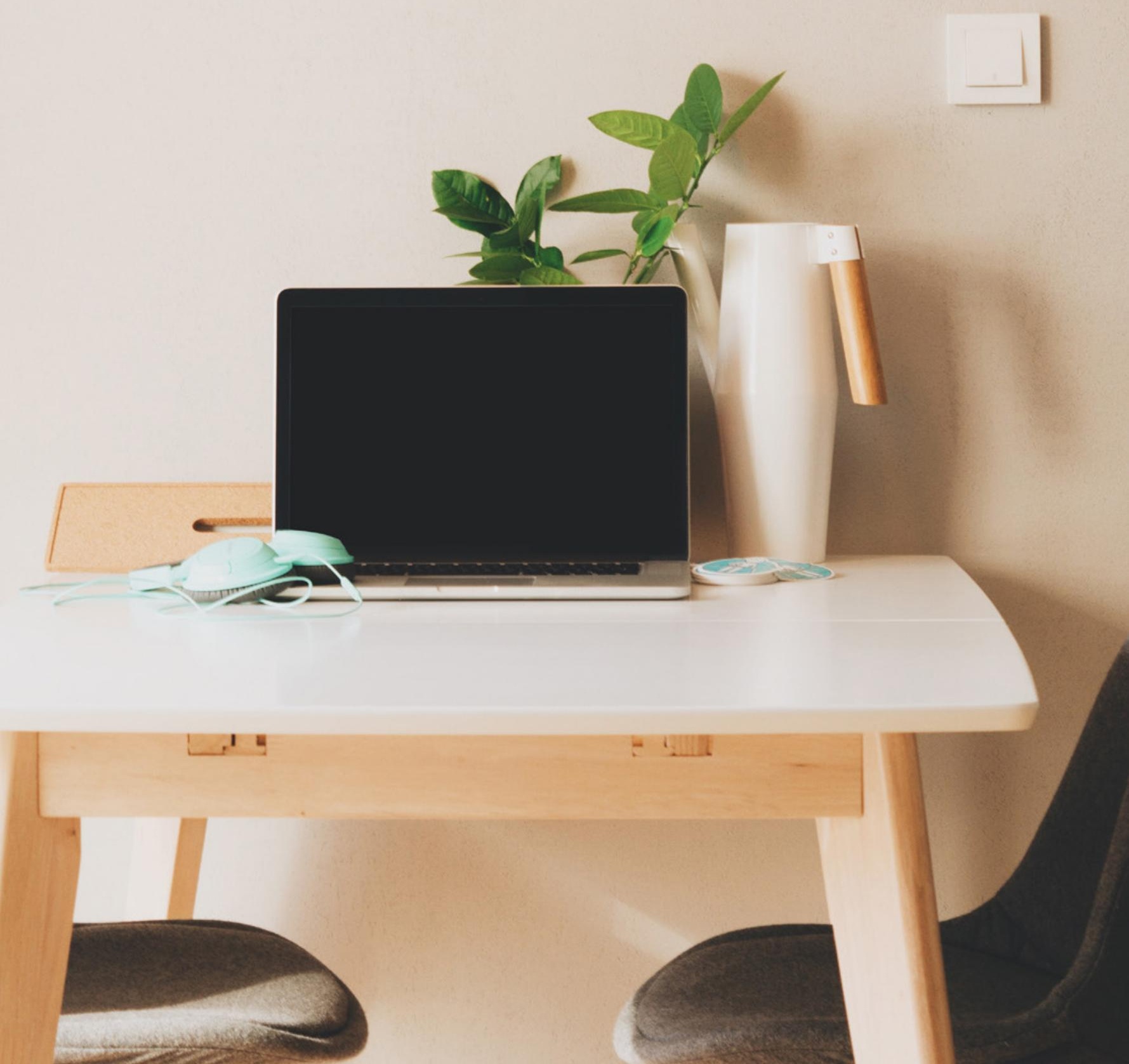





\section{Working environment and work retention}

Otto Melchior Poulsen (project leader), Johann Fridrik Fridriksson, Kristinn

Tómasson, Tove Midtsundstad, Ingrid Sivesind Mehlum, Anne Inga Hilsen, Kerstin Nilsson and Maria Albin

TemaNord 2017:559 


\section{Working environment and work retention}

Otto Melchior Poulsen (project leader), Johann Fridrik Fridriksson, Kristinn Tómasson, Tove Midtsundstad, Ingrid Sivesind Mehlum, Anne Inga Hilsen, Kerstin Nilsson and Maria Albin

ISBN 978-92-893-5196-6 (PRINT)

ISBN 978-92-893-5197-3 (PDF)

ISBN 978-92-893-5198-o (EPUB)

http://dx.doi.org/10.6027/TN2017-559

TemaNord 2017:559

ISSN $0908-6692$

Standard: PDF/UA-1

ISO 14289-1

(c) Nordic Council of Ministers 2017

Cover photo: unsplash.com

Print: Rosendahls

Printed in Denmark

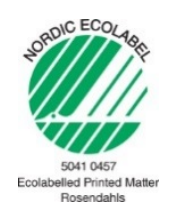

\section{Disclaimer}

This publication was funded by the Nordic Council of Ministers. However, the content does not necessarily reflect the Nordic Council of Ministers' views, opinions, attitudes or recommendations.

\section{Rights and permissions}

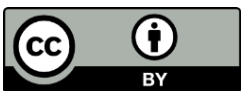

This work is made available under the Creative Commons Attribution 4.0 International license (CC BY 4.0) https://creativecommons.org/licenses/by/4.0.

Translations: If you translate this work, please include the following disclaimer: This translation was not produced by the Nordic Council of Ministers and should not be construed as official. The Nordic Council of Ministers cannot be held responsible for the translation or any errors in it.

Adaptations: If you adapt this work, please include the following disclaimer along with the attribution: This is an adaptation of an original work by the Nordic Council of Ministers. Responsibility for the views and opinions expressed in the adaptation rests solely with its author(s). The views and opinions in this adaptation have not been approved by the Nordic Council of Ministers. 
Third-party content: The Nordic Council of Ministers does not necessarily own every single part of this work. The Nordic Council of Ministers cannot, therefore, guarantee that the reuse of third-party content does not infringe the copyright of the third party. If you wish to reuse any third-party content, you bear the risks associated with any such rights violations. You are responsible for determining whether there is a need to obtain permission for the use of third-party content, and if so, for obtaining the relevant permission from the copyright holder. Examples of third-party content may include, but are not limited to, tables, figures or images.

Photo rights (further permission required for reuse)

Any queries regarding rights and licences should be addressed to:

Nordic Council of Ministers/Publication Unit

Ved Stranden 18

DK-1061 Copenhagen K

Denmark

Phone +4533960200

pub@norden.org

\section{Nordic co-operation}

Nordic co-operation is one of the world's most extensive forms of regional collaboration, involving Denmark, Finland, Iceland, Norway, Sweden, and the Faroe Islands, Greenland and Åland.

Nordic co-operation has firm traditions in politics, economics and culture and plays an important role in European and international forums. The Nordic community strives for a strong Nordic Region in a strong Europe.

Nordic co-operation promotes regional interests and values in a global world. The values shared by the Nordic countries help make the region one of the most innovative and competitive in the world.

The Nordic Council of Ministers

Nordens Hus

Ved Stranden 18

DK-1061 Copenhagen K, Denmark

Tel.: +4533960200 www.norden.org

Download Nordic publications at www.norden.org/nordpub 


\section{Contents}

Preface.

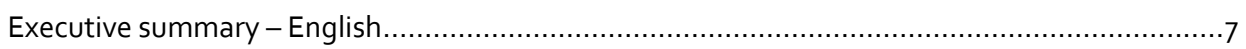

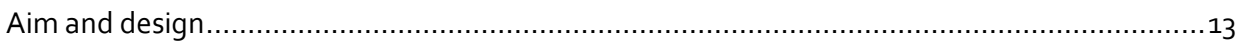

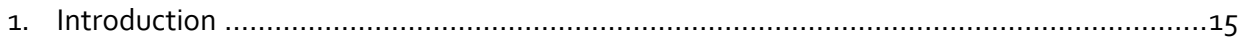

1.1 The ageing population and labour market participation of older workers................15

1.2 Conceptual models explaining labour market exit of older workers..........................16

2. Exit culture and the pension schemes in the Nordic countries.....................................23

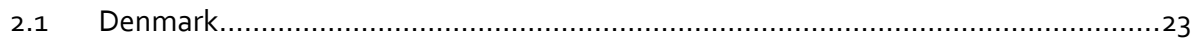

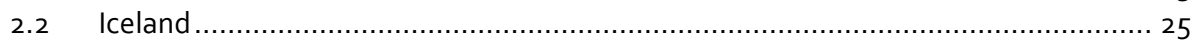

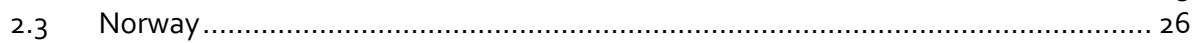

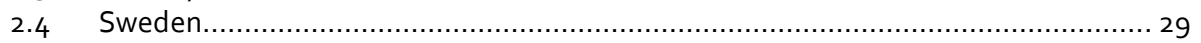

3. The complexity in causes and processes of retirement .......................................... 31

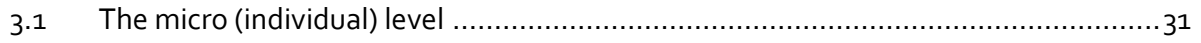

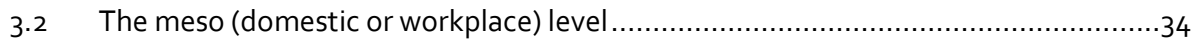

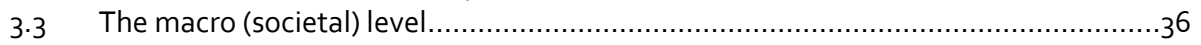

4. The working environment and work retention of older workers....................................41

4.1 The fraction of labour market exit attributable to the working environment ............41

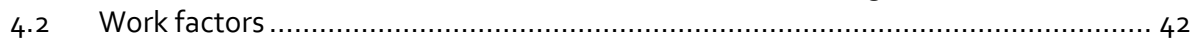

4.3 Human resource management (HRM) and organisational processes.......................53

$4.4 \quad$ The working environment of older workers ................................................. 60

4.5 Older workers (55-64 years) compared with younger workers (25-54 years) in

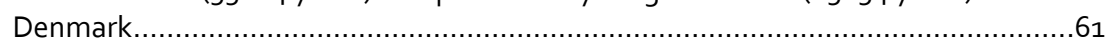

4.6 Comparison of working environment of older workers in Denmark, Norway, Sweden

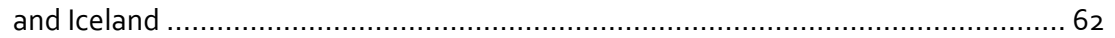

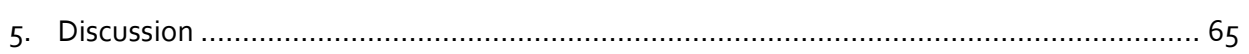

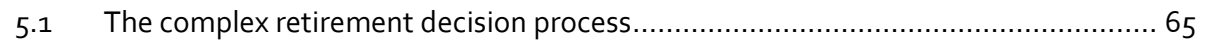

5.2 Major differences between the Nordic countries in exit culture, labour market

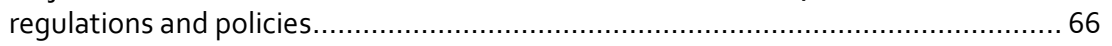

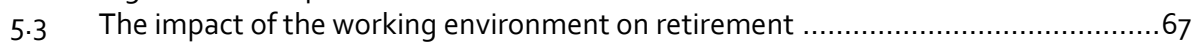

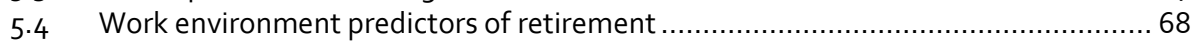

5.5 Comparison of the working environment of older workers in the Nordic countries ...71

5.6 Effects of workplace interventions to increase retention of older workers................71

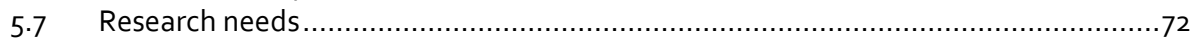

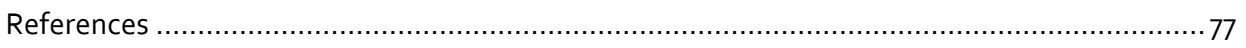

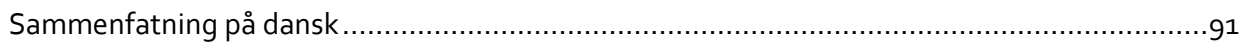

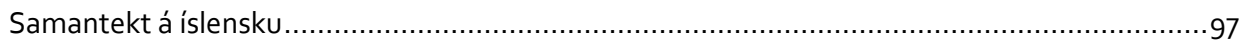

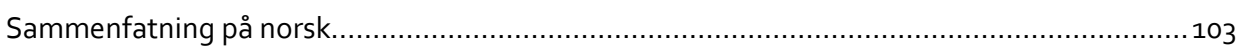

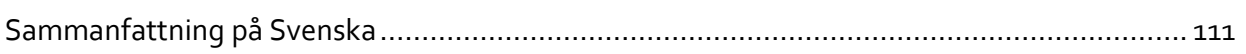

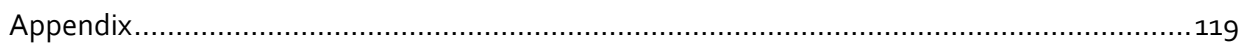





\section{Preface}

Due to demographic changes resulting in an ageing population, a major decrease in the fraction of the population being at working age is foreseen in the Nordic, and European countries. In near future, this is foreseen to increase pressure on the Nordic and European welfare systems. To reduce this pressure increased work participation among older workers is now high on the political agenda, both in the Nordic countries and in most other countries in the western hemisphere, and pension schemes are changed to increase retirement ages (OECD, 2015a).

Increased work participation among older workers was also on the strategic research agenda of the Joint Program Initiative. " "More Years Better Lives" (JPI MYBL). As part of the JPI MYBL Working Group 3 "Work \& Productivity" it was decided, in 2014, on a fast track activity JPI UEP ("Understanding Employment Participation") to create a comprehend sive overview on research and current knowledge on the main determinants of work participation among older workers, as well as the individual, institutional and societal reasons for early retirement in Europe, and to identify major knowledge gaps highlighting needs for future cross-country and interdisciplinary research. The report from the JPI UEP project was published February 2015 (Hasselhorn \& Apt, 2015). The participating countries in JPI UEP (Austria, Belgium, Canada, Denmark, Finland, Germany, Netherlands, Norway, Poland, Sweden, and UK) prepared national reports on current knowledge covering both scientific literature and grey literature, and major findings across countries were summarized in the joint JPI UEP report.

Autumn 2015 the Working Environment Committee ("Arbejdsmiljøudvalget") under the Nordic Council of Ministers granted funds for the present collaborative Nordic project no. 16048 "The impact of the working environment on work retention of older workers" ("Arbejdsmiljøets betydning for fastholdelse af ældre arbejdstagere").

The Nordic project was originally planned as collaboration between Denmark, Finland, Norway and Sweden - all participated in and prepared national reports for the JPI UEP Fast Track project. However, due to profound financial downsizing and large organisational changes at the Finnish Institute of Occupational Health (FIOH), the Finnish participants in the project subsequently declared to be unable to carry out the project. Instead, researchers from Iceland agreed to participate.

The project group consisted of the following participants from four Nordic countries:

- Denmark: Chief consultant Otto Melchior Poulsen, M.Sc., Dr. Vet. Sci. (project leader), the National Research Centre for the Working Environment

${ }^{1}$ Joint Program Initiatives have been launched by the European Commission since 2008 to promote cross national research collaboration within highly prioritized research areas. Both EU member states and countries outside EU can participate. 
- Iceland: Medical director Kristinn Tómasson, dr.med, and Johann Fridrik Fridriksson, Administration for Occcupational Health \& Safety

- Norway: Associate professor at University College Southeast Norway, PhD and Senior Scientist Anne Inga Hilsen, PhD and Senior Scientist Tove Midtsundstad, Fafo Institute for Labour and Social Research. Dept. head of occupational medicine Ingrid Sivesind Mehlum, MD PhD, Department of Occupational Medicine and Epidemiology, STAMI

- Sweden: Professor, senior consultant, Maria Albin, MD, Dr.Med.Sci., Unit of Occupational Medicine, Institute of Environmental Medicine, Karolinska Institute, Stockholm. Assistant professor Kerstin Nilsson, PhD, Dr.Med.Sc, Department of Occupational and Environmental Medicin, Lund University, Sweden \& Department of Work Science, Business Economics and Environmental Phycology, Swedish university of Agricultural Sciences

Inputs to the current report from Denmark, Norway and Sweden were based on revised versions of national reports originally prepared for the JPI UEP project. In the revised reports, more papers were included, and all papers were critically evaluated with particular emphasis on elucidating the impact of the working environment. The revised national reports are available upon request and can be freely downloaded from the webpages of the participation institutions. For Iceland a short national report has been prepared.

In addition, national workshops have been arranged in each participating countries to exchange knowledge and discus the practical implications of the current knowledge with the labour market parties and other stake holders. The national workshops were held in January 2017 in Denmark, in April 2017 in Iceland, in November and December 2016 in Norway, and in October and November 2016 in Sweden. 


\section{Executive summary - English}

The working environment is rarely the sole cause of early retirement. In most cases, the working environment interacts with a multitude of other factors at the micro (individual health, economy etc.), meso (workplace, family and close social network) and macro (the social security system, labour market legislation and regulation) level in the decision to retire or continue working. This is clearly illustrated in the theoretical framework proposed by Nilsson (2016) (figure 1). Two major perspectives exist on labour market retention of older workers:

- The "vulnerable" older worker perspective has focus on the large group of older workers, with limited resources due to attrition, health problems and lack of competences, who have particular needs for protection and work adaptation if they are to, sustainably, extend their work life.

- The resourceful older worker perspective has focus on the group of older workers, who have excellent health and many competences. The workplaces consider them a valuable and productive resource, particularly if their high experience can be utilized. In order to extend the work life of this group of workers, the workplace needs to focus on improving the job satisfaction.

Across the four Nordic countries - Denmark, Iceland, Norway and Sweden - significant differences in retirement age exist, and these differences may, to some extent, be attributable to historical, as well as current differences in exit culture, pension systems, labour market regulations and policies. One major difference is that Denmark has had an early exit culture, in which early retirement has been used to reduce the labour force in periods of high unemployment. Consequently, early retirement is widely expected and socially accepted in Denmark. In contrast, the three other countries have a late exit culture in which unemployment has been combated in all age groups. Job security is low in Denmark, but high in the other countries. Hence, unemployment rates of older workers are high in Denmark. Exit via disability pension is rare in Denmark and Iceland, but frequent in Norway and Sweden. Hence, in Denmark and Iceland, older workers with health problems may not have the option of disability pension, and they may instead be forced to take voluntary early retirement. With recent lower accessibility to disability pension, voluntary early retirement increased in Sweden. 


\section{The impact of the working environment on retirement}

Estimation of the fraction of retirement attributable to the working environment has only been made for transition to disability pension and sickness absence, but not for transition to voluntary early retirement. The estimates are highly health related, and knowledge is lacking on the relative impact of other work-related predictors of voluntary early retirement (e.g. job satisfaction and motivation). In Denmark, a large fraction of disability retirement is attributable to high physical work demands (21\% for men and $34 \%$ for women), and two psychosocial work factors (decision authority and variation) could each explain 10-15\% of the risk of disability retirement. Similar results were obtained in Norway, where five psychosocial and eight mechanical (ergonomic) risk factors at work could explain $45 \%$ of disability retirement. Finally, $30 \%$ of long-term sickness absence is attributable to the psychosocial working environment in Denmark, and between $31-54 \%$ of the social gradient in long-term sickness absence is attributable to the working environment in Norway.

\section{Working environment predictors of retirement}

The association between several different working environment factors and labour market exit has been studied in detail in all Nordic countries, and comparable results have been very similar. We therefore suggest that evidence from one country may be considered valid in the other Nordic countries as well.

We conclude the following working environment predictors of early labour market exit are well-documented: Occupational accidents, whole-body vibration, physical work demands (e.g. strenuous work, heavy lifting, prolonged standing), quantitative work demands (e.g. work speed and time pressure), job control/autonomy/influence at work, leadership support, conflicts at work and bullying/harassment, job satisfaction and age discrimination. In addition, less strong but still moderate documentation exists for possibility for competence development. Finally, limited Nordic research has been made on the impact of chemical work factors, noise, shift work, colleague/fellowship support, organisational commitment, and fear of reorganization on early labour market exit.

In all Nordic countries, there is a strong social class gradient in early exit to retirement, and social class, health and working environment are closely linked. The effects of recently more restrictive welfare systems, e.g. in accessibility to disability pension, with regard to health inequalities between men and women and between socioeconomic groups have not been studied in detail. 


\section{Comparison of the working environment of older workers in the Nordic countries}

National surveys on working environment and health are carried out in Denmark, Iceland, Norway and Sweden. Comparison of data from the four countries reveals similarities, but also distinct differences.

Danish older blue collar women report far more exposure than men to work with monotonous movements, whereas blue collar women and men in Norway and Sweden report approximately the same exposure to monotonous movements. Moreover, In Norway and Sweden older blue collar women tend to report less exposure to physical strenuous work (particularly low in Sweden), less exposure to heavy lifting (particularly low in Norway), and less exposure to work with hands lifted above shoulder than older blue collar men, whereas the opposite is the case in Denmark. In general, the physical working environment of Danish blue collar women appears to be more demanding than that of Norwegian and Swedish older blue collar women.

Danish and Swedish older workers report approximately the same, high exposure to work in awkward position, and to work with hands lifted above shoulder. For both physical working environment factors, the exposures far exceed the exposures of Norwegian older workers. Danish and Swedish older men are also more exposed to vibrations and loud noise than Norwegian older men.

Danish older workers report far more occupational accidents than older workers in Norway and Iceland. In Sweden, occupational accidents and injuries are generally higher among the older workers than for other age groups. However, there is also a difference in occupational injuries between different sectors. This is probably due to the fact that retirement age is different in different sectors. The proportion of occupational injuries with fatal outcome is highest among farmers and forest workers.

Bullying/harassments are experienced by a far larger fraction of older workers in Denmark, than in Sweden (intermediary) and Norway (very low). Norwegian older workers experience more support and help from nearest leader than older workers in Sweden and Denmark. On the other hand, Swedish and Danish older workers experience more often control on how work is done than Norwegian older workers.

Altogether, the physical and psychosocial working environment of Norwegian older workers generally appears to be better than that of older workers in Sweden and Denmark.

\section{Effects of workplace interventions to increase retention of older workers}

In Denmark and Norway less than half of the workplaces take practical actions to promote retention of older workers. Most frequently, the workplace policies and activities aim to provide possibility for stepping down and get a gradual exit from the labour market. The activities mainly comprise of flexible work-time, work-time reduction, more days on leave/holiday, and bonuses. More rarely, the activities include reduced workload, 
improved ergonomics, or competence development. Effects of companies' work-place policies and activities to increase retention of older workers have only been systematic evaluated in Norway. In general, these studies find that interventions offered by Norwegian companies have limited effect on early retirement and sickness absence. However, they find that companies' interventions targeted at workers with health problems and reduced work capacity, reduce the probability of disability pensioning, and that offering of extra days off and bonuses postpones voluntary early retirement. In Sweden, most workplaces do not have any policy for retention of older employees. Only $5 \%$ of the managers in Swedish municipal organisations reported that there were measures to retain older employees in their organisation. However, the managers who indicated having measures, described these as health and fitness activities, skills transfer projects between generations, older employees being able to reduce their working hours and specific mentoring/tutoring projects.

Failure to demonstrate general effects does not rule out that positive effects may occur for some groups of workers, in some companies and industries. In all Nordic countries, several case stories exist, in which workplaces state to have retained older workers successfully due to specific interventions.

Even though a good working environment may be of paramount importance for retention of older workers, the existing knowledge is sparse regarding the effects on retirement behaviours of interventions to improve the working environment. The current knowledge indicates a great potential in developing workplace interventions which combine prevention of working environment risk factors (e.g. risk factors for accidents, strenuous work/high physical work demands, insufficient recovery between work shifts, quantitative work demands, conflicts at work and bullying/harassment, and age discrimination) with increment of job satisfaction through increased control/influence, possibilities for development and recognition from management.

\section{Research needs}

The project has identified research needs linked to the following themes:

- Achievement of a sustainable work-life balance for all. More research is needed on effective workplace policies and interventions to increase sustainable retention of older workers. In particular, knowledge is needed for older low-educated women workers who are stuck in jobs with physical high demands (e.g. health care, service and cleaning). In addition, immigrant workers often have physically demanding manual work to a higher degree than could be expected from their educational level. The current knowledge on how to prevent early labour market exit among older immigrant workers is sparse. Finally, the fraction of older workers with debilitating chronic diseases is expected to increase in future. Research is needed on work adaptation to accommodate these older workers. There is a need for new workplace interventions which combine prevention of working environment risk factors and age discrimination with increment of job 
satisfaction of the employees. In addition, there is urgent need for more "from research to practice" knowledge on how to disseminate knowledge on efficient interventions to the workplaces.

- Long-term consequences of an extended work-life. Particularly for low-educated older workers with straining work exposures, more knowledge is needed on potential negative consequences of longer and cumulative exposure to occupational hazards. Hence, evaluation of workplace policies and interventions should not only focus on work retention (i.e. expected and actual retirement age) but also on workers' health and well-being during the extended work life and after retirement. An important shortcoming relates to lack of knowledge on effects of transitions between different social benefit schemes (unemployment, sickness absence, social security aids, and disability schemes). In theory, regulations of the pension system - restricting the access to early retirement - may not necessarily increase the fraction of older people being at work at the labour market.

Alternatively, increased transfer to different social benefit schemes may occur, particularly for older people with low labour market mobility due to lack of education and/or chronic health conditions.

- The dynamics of the retirement process. So far, most studies have considered retirement a single, finished event, not taking into account that the decision to retire and the retirement process itself may extend several years. A longer (life course) perspective is needed on work ability and work attitudes, how these are changing over time, and how older workers gradually adapt to the future life as pensioners. More knowledge is needed on how health, well-being and quality of life change during the retirement process. More knowledge is also needed on possible positive effects of voluntary part-time employment in combination with partial retirement.

- The workplace perspective. Less than half of the workplaces (in Denmark and Norway) take practical actions to promote retention of older workers, and even though knowledge exists in Norway, more knowledge is urgently needed in Denmark, Iceland and Sweden on the motives and perspectives of the workplaces: Why do some workplaces - but not all - decide to recruit and/or retain older workers? Which types of older workers are offered the senior retention interventions and why? Knowledge is lacking on the actual needs of small and medium size enterprises (SMEs) in particular, and how these needs can be met. Potentially important case stories exist in workplaces (e.g. whole sale and building markets) that have actively recruited senior employees to utilize their experience, but the cases have not been systematically described, and the current knowledge on effects of this type of senior policy is sparse. Finally, the practical use of research-based knowledge at the workplaces is very limited. It may well be that many workplaces do not have the necessary resources to gather knowledge to inform and support their workplace policies and practical activities, and lack of knowledge may be an important barrier to sustainable extended work life, 
particularly at SMEs. Therefore, there is also a strong need for more efficient knowledge dissemination from research to practice at workplaces.

- Combating age discrimination. In all Nordic countries, age discrimination occurs. The most prominent effect of age discrimination is that older workers have very limited possibilities to get a new job if they become unemployed, and therefore often are either stuck in a job in which the demands exceed their work capacity or are forced to take early retirement. Also, older workers are often not offered competence development. Effective ways to combat age discrimination need to be developed, including how to change cultural perceptions of older workers at the society level and negative attitudes and behaviours at the workplaces. However, the workplaces may have objective reasons for being reluctant to hire older workers, e.g. due to seniority-based salary systems. Hence, there is also a need to look more closely at the workplace perspective, and to answer the questions: What are the objective reasons for workplaces being reluctant to hire older workers? And how can the needs of the workplaces be met?

- Combating stigmatization. If labour market policies and workplace senior policies and activities focus on older workers as potentially "vulnerable", and if older workers are selectively entitled to a better working environment and better work condition than their younger counterparts, there are risks of stigmatization. Stigmatization may have severe negative consequences, i.e. tension between age groups resulting in reduced social support and coherence, reduced workplace commitment, reduced job satisfaction etc. Little is known on why and when stigmatization occurs, and what the actual consequences are. Increased knowledge about efficient use at the workplace of the differences in capabilities between younger and older workers in e.g. mentorship, composition of working teams, etc., may be an important component in this. 


\section{Aim and design}

The aim of the project is to prepare a comparative overview on the current knowledge on determinants of work participation for older workers in the Nordic countries, with particular emphasis on the impact of the working environment, and to disseminate the gathered knowledge in the Nordic countries.

The Working Environment Committee under the Nordic Council of Ministers has requested a critical review of the current knowledge. We have aimed to meet this request but it needs to be emphasized that the standardized methods for critical reviews of scientific literature are not applicable on the comprehensive grey literature, which contains a substantial part of the total knowledge base in this field in the Nordic countries. Consequently, we have not rated the degree of scientific evidence. Instead, we have considered the type, number and size of the existing studies, and conclusions are considered more certain if supported by several studies.

The Nordic national reports from the JPI UEP project provide an important starting point. We have prepared revised versions of the national reports putting particular emphasis on the impact of the working environment on decision or ability to retire or continue working. For the revision of the national reports, additional scientific and grey literature was systematically searched in databases on national reports, and a thorough web search was performed. In addition, relevant national research institutions were contacted and asked to provide additional scientific material.

Two major perspectives exist on labour market retention of older workers:

- The "vulnerable" older worker perspective has focus on the large group of older workers, with limited resources due to attrition, health problems and lack of competences, who have particular needs for protection and work accommodation if they are to extend their work life in a sustainable manner. For this group causal similarities may exist between transition to state pension, voluntary early retirement, disability pension, long-term sickness absence, and unemployment. Even though disability pension, long-term sickness absence, and unemployment are not restricted only to older workers, these outcomes have to some extend been included in the report, because risk factors for these outcomes are likely also to be risk factors for transition to state pension and voluntary early retirement.

- The resourceful older worker perspective has focus on the group of older workers, who have excellent health and many competences. The workplaces consider these workers to be a strong and productive resource, particularly if their high experience can be utilized. In order to extend the work life of this group of workers the workplace needs to focus on improving the job satisfaction. For this group the outcomes of interest in the report are intention to retire late and late retirement. 
The draft Nordic report was presented at a closed workshop in each of the participating Nordic countries. The workshops enabled representatives from the labour market parties and the working environment authorities to discuss, comment on and give suggestions to the conclusions and recommendations of the Nordic report. At the workshops, the Nordic report was also discussed in relation to the new EU-OSHA recommendations ("Safer and healthier work at any age", July 2016). 


\section{Introduction}

\subsection{The ageing population and labour market participation of older workers}

Even though the challenges related to the ageing population are of major political concern in all European countries, it should be emphasized that the ageing of the population until 2050 in the Nordic countries is foreseen to be less dramatic, on average, than in the rest of Europe. In 2050 the fraction of the population being age $65^{+}$ in percentage of the population age $15-64$ years (the "ageing ratio") is expected to be approximately $40 \%$ in the Nordic countries (DK: $41 \%$ (increasing from $28 \%$ in 2014), IS: 37.5\%, NO: 40\%, SE: 41\%) compared to 50\% in EU-27. The highest ageing ratio in 2050 in Europe is expected to be in Germany (58\%) (Andersen in Jensen \& Rostgaard, 2015).

The labour market participation of older workers varies between the Nordic countries, but it is higher than in the rest of EU OECD (Jensen \& Madsen in Jensen \& Rostgaard, 2015). Data from OECD statistics shows that in the fourth quarter of 2015 the employment rate of the age group $55^{-64}$ years is $64.6 \%$ in Denmark, $83.9 \%$ in Iceland, $71.9 \%$ in Norway and 74.7\% in Sweden (OECD 2015b). OECD has also provided data on the average effective age of retirement (OECD 2015c). Data for the Nordic countries are extracted in Table 1. The average for OECD was 58.5 years.

Table 1: Average effective age of retirement (2009-2014)

\begin{tabular}{lll} 
Country & \multicolumn{2}{c}{ Average effective age } \\
& Men & Women \\
\hline Denmark & 63.0 years & 60.6 years \\
Finland & 61.9 years & 62.3 years \\
Iceland & 69.4 years & 68.0 years \\
Norway & 65.2 years & 64.3 years \\
Sweden & 65.2 years & 64.2 years \\
\hline
\end{tabular}

As shown in Table 1, the average effective age of retirement is essentially the same in Norway and Sweden and well above the average effective age of retirement in Denmark (and Finland). Iceland has a remarkable high effective age of retirement, which for both men and women is well above that of Sweden and Norway.

A comparison between OECD countries revealed that change in labour market participation for the age group 60-64 years during the period from 1995 to 2011 was

\footnotetext{
2 The average effective age of retirement is defined as the average age of exit from the labour force during a 5 -year period. Labour force (net) exits are estimated by taking the difference in the participation rate for each 5 -year age group ( 40 and over) at the beginning of the period and the rate for the corresponding age group aged 5 -years older at the end of the period.
} 
negative in Iceland (-5\%), positive but modest in Denmark (approx. $3 \%$ ) and in Norway (approx. 4\%) and profound in Sweden (approx. 17\%) and Finland (approx. 22\%). For the age group $65-69$ years the change in labour market participation was less conspicuous (Iceland -9\%, Denmark 2\%, Sweden 4\%, Norway 6\%, and Finland 8\%) (Larsen \& Pedersen, 2013).

\subsection{Conceptual models explaining labour market exit of older workers}

To enable a theoretical understanding and analyses of causes and effects of labour market participation of older workers, several different conceptual models have been proposed. Three models are briefly presented. All models emphasize the high complexity in causes of labour market exit.

\subsubsection{Push, Pull, Jump, Stay and Stuck explanations}

Since the beginning of the goties, one widespread theoretical understanding of labour market exit of older workers has been based on a conceptual model with three different types of explanations: Push, Pull and Jump (Bruusgard et al. in Halvorsen 1994; Jensen in Andersen \& Jensen, 2011; Midtsundstad 2015b). Two additional explanations - Stay and Stuck - were introduced by two Norwegian researchers in 2003 (Snartland \& Øverbye, 2003).

Push explanations refer to mechanisms pushing older workers involuntarily out of the labour market. The Push mechanisms are mainly in function among the weakest and less educated older workers, and in general, the workers do not want to leave the labour market. Three different Push mechanisms may exist (Bruusgard et al. in Halvorsen, 1994):

- Push mechanisms related to imbalance between work demands and work capacity. High work demands may be a strong Push factor particularly if health problems reduce the work capacity so that it is increasingly difficult, and in the end impossible, to honour the work demands (see section 4.1.1.). Lack of competences may also be an important Push factor, particularly if new competences are needed to meet new and changing work demands.

- Social Push mechanisms at the workplace. An important Push factor may be pressure from management or colleagues to retire early. Also older employees may tend to be picked out more frequently when downsizing occurs. There may be several different reasons for this. One reason may be stereotypical negative cognitions of ageing, i.e. ageing may be associated with reduced productivity and efficiency, reduced motivation, and lower flexibility and readiness for changes (see section 5.4.3. for more details). Such negative cognitions may be selffulfilling, i.e. older workers may less likely be offered training or education to 
obtain new competences if they are believed to lack motivation and readiness to changes, and this lack of new competences may eventually render them less productive. Availability of generous early retirement schemes also contributes to making age discrimination at the workplaces more socially acceptable. On the other hand positive social relations to management and colleagues may strongly motivate older workers to continue working even though they could retire.

- Economic Push mechanisms. The economic Push mechanisms are related to demands for productivity and efficacy in work life. A Push factor at the workplace may be related to seniority based salary systems, which are widely used in the Nordic countries. If older workers get a profoundly higher salary merely due to higher seniority, the workplace may be more inclined to hire and retain younger workers. This may partly explain why unemployment is a strong Push factor, particularly for elderly workers with no or short education. Unemployed older workers, who are unable to get a new job, tend to resign and retire early.

Pull explanations are positive mechanisms pulling older workers voluntarily out of the labour market. Pull factors are external economic (e.g. availability of generous early retirement schemes) or sociological stimuli (norms and values), e.g. related to attitudes in family or close friends and colleagues. The ordinary state pension age and the minimum age for early voluntary retirement (e.g. "efterløn" in Denmark and the contractual early retirement scheme AFP in Norway) are important examples of sociological Pull factors. These age limits may represent norms for when it is socially acceptable to retire, and the symbolic importance of these age limits may exist regardless of the economic content of the pension.

Jump explanations are also positive mechanisms causing voluntarily exit from the labour market. But contrary to Pull factors, Jump factors are internally motivated, i.e. the desire to do something new in an active and meaningful third age. Consequently, Jump may be linked to new life projects expected to bring positive experiences (e.g. a new hobby or travel around the world), but Jump may also simply be motivated by a desire to have more time for social activities with spouse, relatives and friends.

Stuck explanations refer to negative mechanisms causing older workers to continue working even though they would rather retire. Stuck factors may simply be considered the opposite of the previously mentioned Pull factors (Midtsundstad, 2015b). Hence, Stuck factors are frequently economical, i.e. some older workers cannot afford to retire. This may be the case if the older worker is not entitled to voluntary early retirement pension or if the costs of living are high. However, for some older workers Stuck factors may also be social, i.e. they continue working because they fear social isolation.

Stay explanations are related to positive aspects of working conditions and salary, which motivate older workers to continue working. Stay factors may be considered the opposite of social Push factors in particular (Midtsundstad, 2015b). Positive aspects of work may be that work is perceived as interesting, meaningful and developing, with a good working environment and with good social relations to nearest leader and colleagues (see section 4.1.3.). In this context, a good working environment may be that work demands are adjusted to meet the needs and work capacity of the older 
employees. Typically, this can be obtained through alterations of work content and physical or technical modifications of the work place.

It needs to be emphasized that Push, Pull, Jump, Stuck and Stay explanations are not mutually excluding, and exit from the labour market may have several different explanations acting simultaneously.

\subsubsection{Theoretical framework of Nilsson (2016)}

Based on several years of research (Nilsson, 2005a,b, 2006, 2007, 2011, 2012, 2015a,b, 2016a, b; Nilsson \& Pinzke, 2010; Nilsson et al., 2010, 2011, 2012, 2016a,b) Nilsson has developed a comprehensive theoretical framework for analysing and understanding the high complexity of work life participation of older workers. The theoretical framework presented in figure 1 highlights this complexity.

Older workers' possibility to work is affected by factors at three levels: Macro level Society level; Meso level - Organisational/Enterprise level; Micro level - Individual level

At the Micro level, nine areas affect whether employees can and want to work:

- Self-rated health and diagnoses

- Physical work environment, accidents, physical demands

- psychosocial work environment, stress, effort / reward, threat, violence

- Working hours, work pace, recovery time

- Personal economy

- Family, life partner, leisure interactions, socialisation

- Organisation's and managers' attitudes, (age)discrimination, social participation, social support

- Work satisfaction, stimulating and self-rewarding tasks, core in work

- Competence, skills, knowledge, development possibilities

These nine areas are included in the following four considerations to decide whether to extend working life or retire:

- 1st Consideration: Are self-rated health and illness in relation to physical and mental work environment and working hours, work pace and recovery time best/sufficient as employed or as retired?

- 2nd Consideration: Are personal economy best/sufficient as employed or as retired?

- $\quad 3$ rd Consideration: Is the possibility to contextual participation and social inclusion with others best/sufficient as employed or as retired?

- 4 th Consideration: Is the possibility to meaningful and self-rewarding activities best/sufficient as employed or as retired? 
The nine areas and the four considerations to work life participation are also related to the four different conceptualisation of ageing: Biological ageing, Chronological ageing, Social ageing, and Mental ageing.

Figure 1: The complexity of factors affecting an extended working life (Nilsson, 2016)

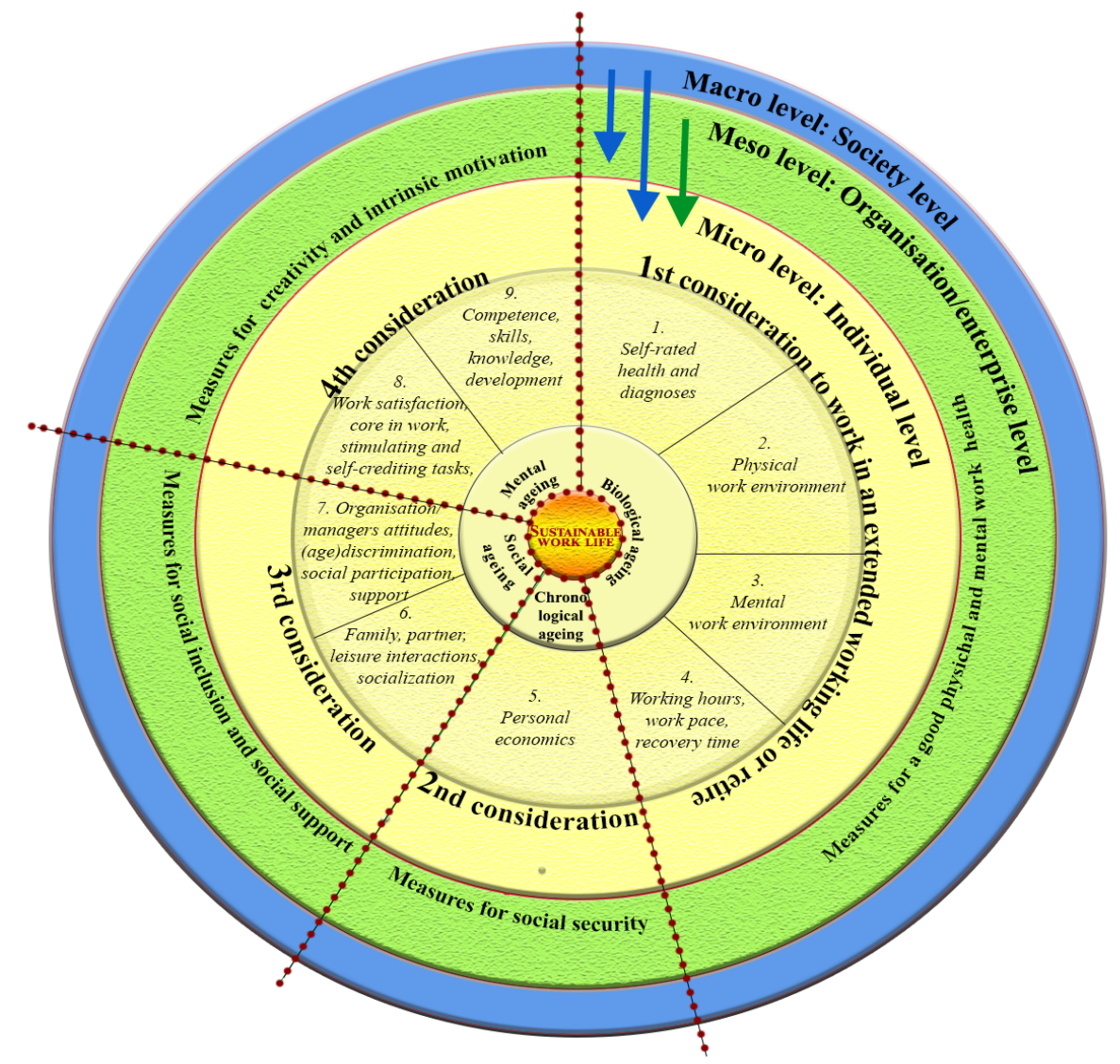

At the Meso level, the older persons' decision to extend work life participation or to retire is affected by the attitudes and activities of organisations/enterprises with respect to:

- creating a good physical and psychosocial (mental) working environment for employees

- creating social security for employees

- ensuring social inclusion and social support for employees (including combating age discrimination).

- stimulating creative possibility and intrinsic motivation to work for employees.

The Macro (society) level affects both organisations/enterprises and individuals. Age policy, communicated through legalisation, regulations, and economic incentives, may create possibilities and barriers for organisations/enterprises and individuals with 
respect to all nine areas included in the four considerations in Figure 1. However, it is seldom considered that, in addition to chronological age, biological, social and mental ageing are also important for the decision to extend work life.

\subsubsection{The conceptual model of Wang \& Shultz (2010)}

In a scientific review of the retirement process from an individual, behavioural perspective, Wang and Shultz (2010) suggested the conceptual model presented in Figure 2. Similar to the theoretical framework of Nilsson (2016), the conceptual model of Wang \& Shultz (2010) does not suggest causal links but merely state that numerous different factors at the micro, meso and macro levels may influence the retirement process. An important point, which is highlighted in the model, is the fact that the retirement process in itself may contain several steps and phases, and the process may occur over a time span of several years. In many studies, the complexity of the retirement process itself is overlooked. For example, predictors for early retirement are frequently studied, but the studies rarely take into consideration differences in the preceding phase of planning retirement or differences in how the subsequent retirement adjustment, including part-time employment, contributes to health and quality of life after retirement.

It should be noticed, that the model includes so-called "bridge employment" 3 which may be considered a particular North American phenomenon (Beehr \& Bennett, 2015). The generous pension schemes, which are typical for the Nordic countries, are very rare in the United States, so the majority of older U.S. workers are, for economic reasons, more or less forced to take part-time "bridge employment" for several years after retirement from their major, career job. Frequently, bridge employment in U.S. is at a lower salary, and with poorer working environment and working conditions. In contrast, In the Nordic countries, part-time employment after retirement is most frequently voluntary, often a continuation of their major career job, and salary and working conditions are good. Consequently, when the model of Wang \& Schultz (2010) is used on retirement processes in the Nordic countries, "Bridge employment" should be substituted with "Voluntary part-time employment".

\footnotetext{
3 Bridge employment is defined simply as working for pay after retirement, or more formally, as labour force participation by older workers after they leave a career job and before they completely and permanently withdraw from the labour force. Thus bridge employment is any kind of paid employment (e.g., part-time, full-time, or self-employment) that employees engage in after they retire from a career job.
} 
Figure 2: Summary of Issues and Relationships Considered in Empirical Studies on the Retirement Process

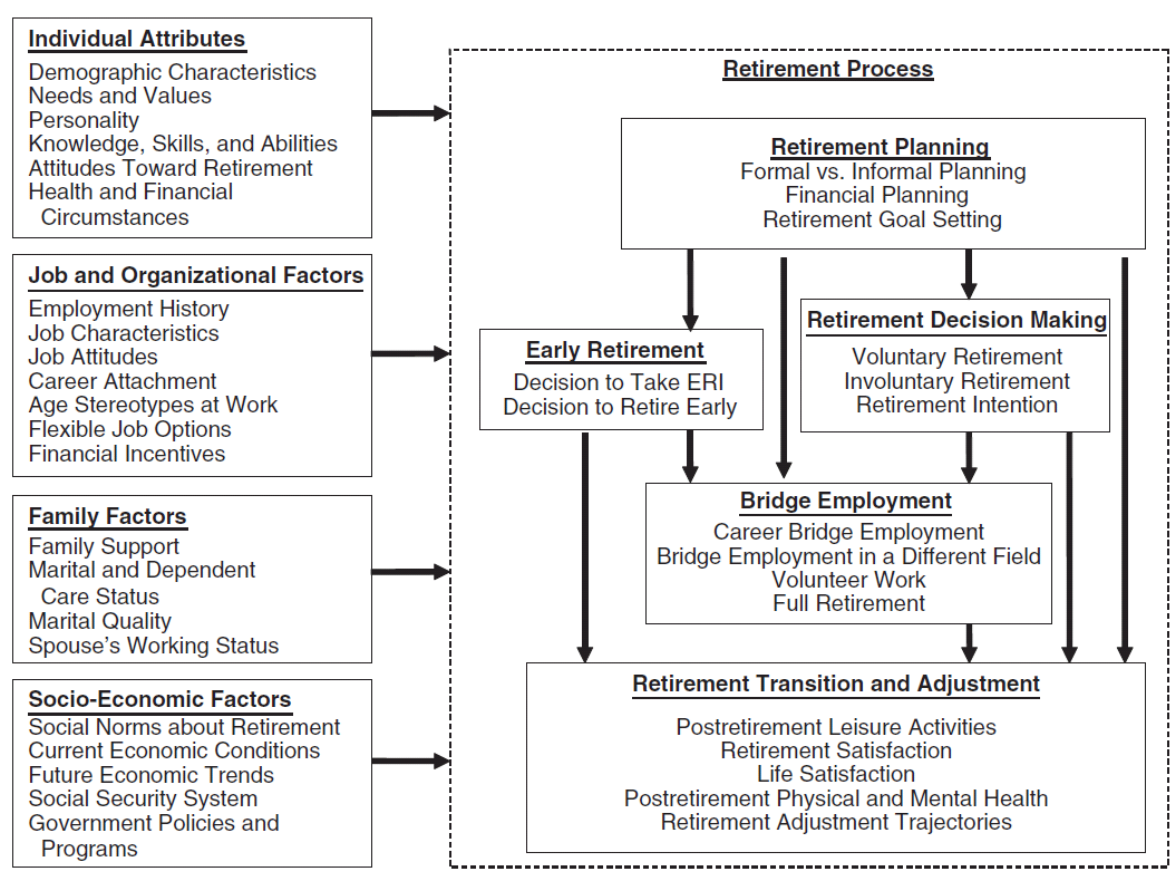

Source: The conceptual model of Wang \& Shultz (2010). 



\section{Exit culture and the pension schemes in the Nordic countries}

At a highly generalized level, distinction can be made between late-exit culture and earlyexit culture, depending on whether the norms and attitudes in the working-age population are in favour of late or early retirement (Hult \& Stattin, 2009; Nilsson, 2016a).

It needs to be emphasized that the exit routes from employment to retirement have become still more heterogeneous and, in Denmark and Norway, the possibility to combine pension and part-time work has increased. In Iceland, the pension is reduced substantially based on the earning so the benefit of part-time employment can be limited. A recent European report states that the increased possibility for part-time work may not translate into a prolonged work-life and more work hours contributed to the national economy (Eurofound, 2016). However, the increased possibility for parttime work makes studies on predictors for retirement behaviours more complex, and little is known on how access to part-time work participation modulates the associations between working environment factors and retirement.

In general, macro economists and politicians consider easy access to pensions and other social security benefits, and the generosity of these schemes to be important Pull factors, stimulating early exit from the labour market (Hult \& Stattin, 2009; Hernæs et al., 2002). In the following, we provide a brief outline of the pension legislations and different social security schemes in the Nordic countries; i.e. old age pension schemes (including both public pension schemes and occupational pension schemes), voluntary early retirement schemes and disability pensions schemes.

\subsection{Denmark}

Since the turn of the century, Denmark has been struggling with an early-exit culture which originated from the goies when early exit was used as a welfare policy to reduce the labour force in times of high unemployment (Hult \& Stattin, 2009). This is clearly reflected in the low effective retirement age in Denmark, compared with Norway and Sweden (see Table 1). Data from OECD demonstrate that the rate of labour market participation for Danes in the age group 6o-64 years (49.6\%) is slightly above the average for OECD (46.6\%), whereas the work participation for Danes in the age group $65-69$ years (above the age limit for state pension) (15.9\%) is well below the average for OECD (21.2\%) (OECD 2015b).

For several years a mandatory retirement age has not existed in Denmark, but employers were permitted to make agreements with their employees that they should retire when they reached the age of 70 . Many employees had this retirement age in their letter of employment. From 1 January 2016 it is by law no longer permitted to enter this type of agreements, and employees can no longer be imposed to retire at a certain age. 
According to the pension act July 2012, the age limit for ordinary state pension will gradually increase from 65 to 67 years or more in 2024. At the same time, pensioners are allowed to work and have a restricted annual earning without reduction in the pension (Zielke Schaarup, 2009). However, the actual fraction of people on state pension working part-time is small.

A law in 1999 made the conditions for being eligible for voluntary early retirement more restricted, and a new "Agreement on later retirement" was pasted in 2011, aiming at making voluntary early retirement less generous. The period for obtaining voluntary early pension will be gradually reduced from five to three years. Persons, who are born before 1954 and fulfil some basic requirements, can obtain voluntary early pension for a period of five years from age 60 to 65 (ordinary state pension age). For persons born in 1954 and 1955, the age limit for entering voluntary early pension gradually increases from 60 years to 62 years, but the beneficiaries can still obtain voluntary early pension for five years because the age limit for ordinary state pension is simultaneous increased from 65 years to 67 years. For persons born later than 1955, the onset of voluntary early pension is further delayed and the period is gradually reduced to three years. Consequently, in future, voluntary early pensions will be for a shorter period (three years) and with later onset. It is possible to work part time alongside with receiving voluntary early retirement, in this case the voluntary early retirement benefits are reduced in proportion to the weekly number of working hours. The fraction of older workers, who have part time work alongside with receiving voluntary early retirement, has been slightly increasing during the period 2003-2009 (Larsen \& Pedersen, 2013).

The labour market participation of older workers age 60-64 years has increased profoundly from $33 \%$ in 2000 to $49 \%$ in 2012 even though the majority of these workers could potentially enter voluntary early retirement. This increase also occurred during the global financial crisis in 2008 (Baadsgaard, 2013). The increase has been suggested to partly reflect changes in legislation in 1999 and later (Larsen \& Pedersen, 2013). However, cohort effects, including gradual improvement of educational level and gradual improvement of health of the older workers have probably also been of importance (Larsen \& Pedersen, 2016). In addition, the fraction of older workers (57 years), who experienced the work as physically demanding, has declined from 60\% in 1997 to approx. $30 \%$ in 2012 . This indicates an improved balance between the physical work demands and the work capacity, which may also have contributed to the increased labour marked participation of older workers (Larsen \& Pedersen, 2016).

"Agreement on later retirement" in 2011 also further limited access to permanent disability pension. In most cases, disability pension will in future be temporary and the workability of pensioners receiving disability pension will be evaluated on a regular basis. The number of Danes receiving disability pension has decreased profoundly since the beginning of 2013 (Statistical Bureau Denmark). Nevertheless, according to a new national economy forecast, the fraction of Danes receiving disability pension will increase from approx. $4 \%$ in 2014 to approx. $5 \%$ in 2060 (LO, 2016a). The Danish Labour Union (LO) argues that a part of this increase may reflect that an increasing number of older workers - due to attrition - will not be capable of continuing to work until state pension when the age limit for entering state pension is increased gradually until 2060. 
Occupational pension schemes are in practice compulsory for all wage earners in Denmark. The voluntary early pension and the subsequent ordinary state pension payments are reduced in proportion to the size of the accumulated occupational pension. Consequently, the voluntary early pension has become far less generous.

In Denmark, high unemployment rates among persons $55^{+}$years pose a particular problem. A law from 2006 on "Senior Work" defines the circumstances for obtaining the right to a so-called "senior job". The municipality, in which an unemployed person age $55^{+}$ years is resident, must offer the person a senior job if access to unemployment benefit is exhausted and the period until access to voluntary early pension is shorter than five years.

\subsection{Iceland}

Iceland has had a long lasting history of high participation in the work market of all ages, including the older workers (see Table 1).

In Iceland, official age of retirement has been 67 years, at which time you can start to receive retirement state pension from the Social Insurance Administration. This can be postponed until the age of 70 years. Certain professions, like police officers, can go earlier on state pension ( 65 years of age) However, in the public sector, it is possible to continue to work longer, but then on an hourly contract basis. In the private sector there is no mandatory retirement age. A bill has been put forward to the Icelandic Parliament to raise the age limit for state pension to 70 years of age, and with the possibility of postponing retirement until the age of 80 years. Later retirement will result in increased pension benefits from the pension fund. At the same time the bill also puts forward the possibility to retire at the age of 65 years but, if so, the retiree only receives half of full state pension.

Everyone who is occupationally active, pays dues into private pension funds. You can start to draw retirement pension by the age of 60 years from these funds. The amount you receive is directly related to the amount you have paid and how well the pension fund has invested the money. For most people retiring before the age of 70 years will result in very significant income cuts, thus the drive to work until 70 years of age is very high. Additionally, the shortage of labour force in Iceland has resulted in a profound late-exit culture, where the need of stimulation from an active labour market policy has not been pressing.

In Iceland, there has been an increasing trend in the percentage of individuals on some form of disability pension from the Social Insurance Administration, from 3.5\% of the population aged 16 to 66 in $1986,5.4 \%$ in $1996,7.2 \%$ in 2006, and finally $9 \%$ of the population aged 16 to 66 in 2015 . The leading causes of disability have been mental disorders and musculoskeletal disorders. In 2012, mental disorders were $42.2 \%$ of all disability pensions among men and $33.7 \%$ among women, while musculoskeletal disorders were $18.1 \%$ and $36.4 \%$, respectively. (http://www.tr.is/media/tolutidindi/Helstorsok-ororku-eftir-sjukdomaflokkum2012.pdf). The importance of musculoskeletal disorders increased significantly with age.

This growing rate of disability pensioning has been a matter of concern for the authorities and pension funds. In 2008 a Work-rehabilitation fund was erected with all employers, the state and the pensions fund paying into the fund. Even though this fund 
has had substantial income, as of today the activities of the fund have not resulted in a lower overall percentage of persons on disability pension.

\subsection{Norway}

Norway has a late-exit culture founded on the long-lasting Norwegian policy tradition of promoting high labour force participation and low unemployment, which is also reflected in high labour force participation of older workers (see section 2.1). However, most important is probably the fact that Norway for years (up to 2011) have had a high statutory pension age; 67 years for both men and women (now it is flexible from age 62 to 75 ), a relative high age limit for termination of job contracts (70 years up to 2015, now 72 years), and that the voluntary early retirement scheme AFP (introduced in 1988) first gave employees the opportunity to retire at age 62 from 1 March 1998 (Midtsundstad, 2011). In other words, before 2011 it was only possible for Norwegian employees to retire before age 62 on a disability pension (except for employees in occupations with a legislated lower age limit, like for example military officers and police officers, who had the opportunity to retire at age 57 if they have been in their occupation for 28 years at that age).

The pension system has, however, been reformed and a new public old age pension scheme came into force in 2011. From then on, the age group 62-66 was given the opportunity to retire on an old-age pension from the National Insurance System (NIS), and a new AFP scheme was introduced in the private sector, replacing the old one. While strict deduction rules had previously been applied if labour incomes exceeded NOK 15,000 per year in combination with payments from the AFP scheme, people were now free to combine the new, private-sector AFP scheme with unlimited income from work. However, this did not apply to recipients of AFP pensions in the public sector.

The reform also enabled 67-year-olds from 2008 on to combine work and retirement, with no deductions from their pension payments. In 2009 and 2010, this rule was also expanded to include 68- and 69-year-olds. Old-age retirees over 70 already had this opportunity. These regulatory amendments have made the combination of work and retirement increasingly common also among the oldest age groups (Bråthen \& Grambo, 2009).

In other words, the pension reform allows employees to draw a pension at any time they want after reaching the age of 62 , irrespective of whether they continue working or not. The precondition is that the accumulated pension entitlements (old age pension from the NIS, AFP and occupational pension schemes) must exceed the minimum pension level (from age 67), when adjustments based on changes in life expectancy are taken into account. The new rules imply that retirement and resignation from work are turned into two independent decisions, and no longer need to be taken at the same time. If retirement is delayed, the annual pension disbursements also increase. In addition, continued employment after the age of 62 will accumulate increased pension entitlements (up to age 75 for old age pension from NIS and up to age 72 for AFP) and thus a higher annual pension when it is finally claimed. Many will therefore have a financial incentive to delay their retirement and to continue working. However, the 
level of future pension benefits and the opportunity to retire early depend considerably on whether the person concerned is entitled to an AFP pension, which covers all public employees, but only about half of all private sector employees (Hippe \& Midtsundstad, 2016), and a beneficial occupational pension.

The pension reform also involved the introduction of a compulsory occupational pension for all wage earners. From 1 January 2007, all companies must have such schemes; most of the legal framework had already been established in this regard. Before 2006, only $50 \%$ of private sector employees were covered by occupational pension schemes.

In addition, a new disability pension system came into force 1 January 2015. The disability benefit from NIS now equals $66 \%$ of yearly income up to $6 \mathrm{G}$ (the basic amount in NIS; NOK 92,576 per 1. May 2016). Calculation of income is based on the three years with highest income during the last five years before illness/injury. Those with low or no income are entitled to a basic benefit. The disability benefit is taxed the same as earned income. It is possible to combine work and disability pension. However, there is a limit to how much income one may earn before the disability benefit is reduced.

In July 2008, all Norwegian employees were also given a statutory right to reduced working hours from the age of 62 years to make it easier for older workers to combine work with a pension (The Working Environment Act $\$ 13$ ). The changes aim to enable these employees to remain in employment even if they do not want to work full time. This is in line with the new NIS, as well as the revised early retirement scheme AFP, both of which contain strong financial incentives to remain in employment - including parttime work - beyond the age of 62 years.

Further arrangements exist in Norwegian working life to encourage continued employment among older employees: employees aged 60 years and over are entitled to an extra holiday week. In the state sector, employees past 62 are also offered 8 to 14 extra days off with pay to encourage older employees to stay longer in employment. These extra days off are part of the collective agreement for state sector employees.

The declaration of intent to cooperate on attaining a more inclusive labour market (IA agreement) was signed on 3 October 2001. The IA agreement was initially signed for a period of four years, later extended from 2006 to 2013, and most recently from 2014 to 2018. On the basis of this IA agreement, the Government and the social partners have committed themselves to seeking to establish a more inclusive labour market for the benefit of the individual employee, the workplaces and society as a whole. Through the agreement, focus has been placed on reducing sickness absence and the use of disability pensions, increasing the retirement age and ensuring the recruitment of people with impaired functioning capacity and other vulnerable groups to the labour market. One goal of the last agreement is to increase the years in employment for 50 year olds by 12 months from 2009 to 2018 . As a result of the IA agreement many companies have incorporated old-age policy measures as part of their personnel policy (Midtsundstad \& Bogen, 2011a; Midtsundstad, 2014). Some employers, especially in the municipal sector, offer reduced working hours without a parallel wage reduction, extra days off and bonuses to older employees who choose to continue working after the age of 62 , rather than to retire. 
Table 2: The Norwegian pension system before the pension reform (-2011)

\begin{tabular}{|c|c|c|c|}
\hline Pension scheme & Private sector with AFP & Private sector without AFP & Public sector \\
\hline $\begin{array}{l}\text { National Insurance } \\
\text { Scheme (NIS) } \\
\text { Disability pension }\end{array}$ & $\begin{array}{l}\text { Partial pension ( } 50-100 \% \text { ) } \\
\text { Benefit-Calculation equals OAP from NIS } \\
\text { (Income last } 3 \text { years before disability + } \\
\text { Some have supp. from OP) } \\
\text { Work - earning test }\end{array}$ & $\begin{array}{l}\text { Partial pension ( } 50-100 \% \text { ) } \\
\text { Benefit-Calculation equals OAP from NIS } \\
\text { (Income last } 3 \text { years before disability + } \\
\text { Some have supp. from OP) } \\
\text { Work - earning test }\end{array}$ & $\begin{array}{l}\text { Partial pension (20-100\%) } \\
\text { Benefit - } 66 \% \\
\text { Work- earning test }\end{array}$ \\
\hline $\begin{array}{l}\text { National Insurance } \\
\text { Scheme (NIS) } \\
\text { Old age pension (OAP) }\end{array}$ & $\begin{array}{l}67 \text { years } \\
40 \text { years (full) } \\
20 \text { best income years (supplement) up to } 6 \mathrm{G} \\
54 \% \text { of earlier income on average }\end{array}$ & $\begin{array}{l}67 \text { years } \\
40 \text { years (full) } \\
20 \text { best income years (supplement) up to } 6 \mathrm{G} \\
54 \% \text { of earlier income on average }\end{array}$ & $\begin{array}{l}67 \text { years } \\
40 \text { years (full) } \\
20 \text { best income years (supplement) } \\
\text { up to } 6 \mathrm{G} \\
54 \% \text { of earlier income on average }\end{array}$ \\
\hline $\begin{array}{l}\text { Contractual early } \\
\text { retirement scheme } \\
\text { (AFP) }\end{array}$ & $\begin{array}{l}\text { 62-66 years } \\
\text { (benefits equals OAP from NIS) }\end{array}$ & & $\begin{array}{l}62-64 \text { years: benefits equals OAP } \\
\text { from NIS } \\
65-66 \text { : equals occ. pens. }\end{array}$ \\
\hline $\begin{array}{l}\text { Occupational pension } \\
\text { (OP) scheme }\end{array}$ & $\begin{array}{l}67 \text { years } \\
\text { Only DB before } 2001 \text { : 60-70\% } \\
\text { Mandatory from } 2006 \text { (OTP) - mostly DC ( } 2 \%)\end{array}$ & $\begin{array}{l}67 \text { years } \\
\text { Only DB before } 2001: 60-70 \% \\
\text { Mandatory from } 2006(\text { OTP) - mostly DC ( } 2 \%)\end{array}$ & $\begin{array}{l}67 \text { years } \\
\text { Defined benefit (DB): } 66 \%\end{array}$ \\
\hline Special age limits & Only a few occupations (pilots, divers etc.) & & $\begin{array}{l}30-40 \% \\
60-(57), 63-(60), 65-(62) \\
\text { (police and military officers, nurses } \\
\text { etc.) }\end{array}$ \\
\hline $\begin{array}{l}\text { Termination of the } \\
\text { employee contract }\end{array}$ & 70 years $(67)$ & 70 years $(67)$ & 70 years (mandatory) \\
\hline
\end{tabular}

Note: $\quad$ NIS = National Insurance Scheme, OAP = Old Age Pension, AFP = contractual early retirement scheme, OP = Occupational pension scheme, $D B=$ defined benefit schemes, $D C=$ defined contribution schemes, WEA = Work Environment Act

Table 3: The Norwegian pension system after the pension reform (2011-)

\begin{tabular}{|c|c|c|c|}
\hline Pension scheme & Private sector with AFP & Private sector without AFP & Public sector \\
\hline National Insurance & Partial pension (20-100\%) & Partial pension (20-100\%) & Partial pension (20-100\%) \\
\hline Scheme (NIS) & $66 \%$ (taxable) & $66 \%$ (taxable) & $66 \%$ (taxable) \\
\hline Disability pension & Work - earning test & Work - earning test & Work-earning test \\
\hline $\begin{array}{l}\text { National Insurance } \\
\text { Scheme (NIS) } \\
\text { Old age pension (OAP) }\end{array}$ & $\begin{array}{l}\text { Withdrawal } 62-75 \text {, actuarial neutral } \\
\text { Accrual - all years in work counts }(13-75)\end{array}$ & $\begin{array}{l}\text { Withdrawal } 62-75 \text {, actuarial neutral } \\
\text { Accrual - all years in work counts }(13-75)\end{array}$ & $\begin{array}{l}\text { Withdrawal } 62-75 \text {, actuarial } \\
\text { neutral (cannot be combined with } \\
\text { AFP) } \\
\text { Accrual - } 13-75\end{array}$ \\
\hline $\begin{array}{l}\text { Contractual early } \\
\text { retirement scheme } \\
\text { (AFP) }\end{array}$ & $\begin{array}{l}\text { 62-70 years, supplementary } \\
\text { Lifelong (actuarial neutral) }\end{array}$ & & $\begin{array}{l}62-64 \text { years: benefits equals OAP } \\
\text { from NIS } \\
65-66 \text { : equals occ. pens. }\end{array}$ \\
\hline $\begin{array}{l}\text { Occupational pension } \\
\text { (OP) scheme }\end{array}$ & $\begin{array}{l}67 \text { years } \\
\text { DB }(23 \%) \text { - lifelong } \\
\text { DC }(67 \%) \text {-often } 10 \text { years }\end{array}$ & $\begin{array}{l}67 \text { years } \\
\text { DB }(23 \%) \text { - lifelong } \\
\text { DC }(67 \%) \text {-often } 10 \text { years }\end{array}$ & $\begin{array}{l}67 \text { years } \\
\text { DB, } 66 \% \text {, lifelong }\end{array}$ \\
\hline Special age limits & Only a few occupations (pilots, divers etc.) & Only a few occupations (pilots, divers etc.) & $\begin{array}{l}30-40 \% \\
60-(57), 63-(60), 65-(62) \\
\text { (police and military officers, } \\
\text { nurses etc.) }\end{array}$ \\
\hline $\begin{array}{l}\text { Termination of the } \\
\text { employee contract }\end{array}$ & 72 years $(70)-$ from 2015 & 72 years $(70)-$ from 2015 & 70 years (mandatory) \\
\hline
\end{tabular}




\section{$3.4 \quad$ Sweden}

Swedish labour market policy has in general aimed at high labour force participation also of older workers, and Sweden has a late-exit culture (Hult \& Stattin, 2009; Nilsson et al., 2016; Kadefors et al., 2017). In 2004, the use of disability pension in Sweden was extremely high compared to other European countries, and more than $10 \%$ of the workforce drew disability pension (Hult \& Stattin, 2009). Nevertheless, the Swedish social insurance reform in 2008 increased the work life participation through 2004-2011 especially among low-educated women and men (Nilsson et al., 2016). However, the tendency to exit working life by early retirement (statutory and occupational retirement from 61-64 years) also increased in this period among the low-educated. Despite this increase in early retirement among the low-educated, the proportion was lower than in the group of the high-educated males and managers, where $28 \%$ took early retirement.

In Sweden, the older workers have a high degree of job security, and probably because the employers have limited possibilities for dismissing older workers, they invest more in development of their competences. As a consequence, Swedish older workers are in general far better educated than Danish older workers (Andersen \& Jensen, 2011).

The Swedish (ordinary) pension system is contribution-based, meaning that the number of working years contributing to the pension determines the size of the pension. The system allows for early retirement at 61 years but with low pension rates. For those with no or low pension from the system, it is possible to get a low tax-financed ordinary pension from the age of 65 .

The new pension system has no fixed pension age. Since year 2000 , it has been possible to retire between 61 and 67 years. The pension is actuarially calculated and can start at age 61 . However, the age when retirement starts, affects the economic benefit. To get full pension, the Swedes have to work until 67 years. This is planned to be delayed until 69 years of age. Currently, the effective retirement age in Sweden is actually close to the ordinary pension age of 65 years (see section 2.1).

To stimulate labour market participation of older workers, a reduction in payroll tax for workers $65^{+}$years was introduced in 2007 , and job security is by law increased to age 67 . In the governmental sector, the use of part-time pension is limited, even though the possibility exists. 



\section{The complexity in causes and processes of retirement}

Even though the focus of the present report is on the impact of the working environment on work retention of older workers, it is important to recognize that the working environment is rarely the sole cause of early retirement, and in most cases, the working environment interacts with a multitude of other factors at the micro-, mesoand macro level in the process of decision to retire or continue working (Nilsson 2003a; Nilsson 2005; Nilsson 2013; Nilsson 2016a). However, these interactions have rarely been studied in all countries, and knowledge is still limited (Wang \& Shultz, 2010; Hasselhorn \& Apt, 2015). In order to put the current knowledge on working environment and retirement into a broader perspective, we will first summarize the current Nordic knowledge on other factors.

\subsection{The micro (individual) level}

\subsubsection{Health}

In all Nordic countries, several studies have shown that ill health is a strong predictor of exit to both disability pension and early voluntary retirement (Midtsundstad 2002a-d; Midtsundstad 2005a,b; Jørgensen et al., 2005; Thielen et al., 2009; Gupta \& Larsen, 2010; Larsen et al., 2011; Midtsundstad \& Nielsen, 2013, 2014a; Nordenmark \& Stattin, 2009; Nilsson et al.; 2016a, b; Kadefors, 2017).

As suggested by Hasselhorn \& Apt (2015), ill health may not be a definitive predictor of exit from work since some older workers with good health decide to retire early and, on the other hand, a fair proportion of older employees with poor health retire late (Lund et al., 2006; Solem et al., 2008; Nilsson et al., 2011; Nilsson 2012; Nilsson et al., 2016b). Solem et al. (2008) find, when analysing LOGG-data, that even among those with the lowest rated health (SF-12), 53\% was employed in the age group $45-54$, about $40 \%$ among those $55-61$, and $25 \%$ in the age group $62-66$ years. A Danish survey among older workers, who continued working above the age of 60 , however, showed that $30 \%$ continued working because they could not afford to retire, and more than half of them reported to have severe pains in muscles and joints (Nielsen Breidahl in Andersen \& Jensen, 2011). This result indicates that Stuck factors may be of particular importance for older low-skilled workers with musculoskeletal health problems.

Furthermore, ill health interacts with socioeconomic conditions in causing early exit from the labour market. III health may reduce the work ability, and inability to cope with high physical job demands may push older workers out of work particularly in 
strenuous, low skilled jobs. A Danish cohort study - using a single-item 10 point scale on work ability - showed that one point decrease in work ability was associated with $33 \%$ increased risk of voluntary early retirement (Sell, 2009). In 1998 in Sweden, all occupations with the highest rates of early exit through disability pension were bluecollar workers (Stattin, 1998). The sick leave and disability pension rates are still highest among low-educated people, especially women, despite the social insurance reform in Sweden in 2008 (Nilsson et al., 2016a,b). However, high-educated men and managers most frequently take early statutory and occupational pension in Sweden. In Norway, disability pension is strongly associated with decreasing years of education (Gravseth et al., 2007, 2008), particularly in case of musculoskeletal diagnoses (Bruusgaard et al., 2010) and mental disorders (Kristensen et al., 2010). In Denmark, a cohort study among Danish elderly care workers showed that health problems, in combination with high physical job demands, were the main reasons for early retirement (Clausen et al., 2014a). This is in agreement with the results of a recent Danish survey among 3,475 adults age $18-75$ years, showing that $20 \%$ of blue collar workers do not expect to continue to work until ordinary state pension age ( 65 years), and slightly more than $20 \%$ of blue collar workers state that they take pain killers daily/weekly to be able to cope with the work demands. In comparison, only $8 \%$ of high education workers take pain killers daily/weekly and only $8 \%$ do not expect to continue working until state pension age (LO, 2016b). The combination of ill health and high physical job demands may, to some extent, explain why ill health is a stronger predictor of voluntary early retirement among women than men. More women than men report musculoskeletal health problems (see section 5.5.) (Work and Health 2014), and many women, who work in the public sector, have physically strenuous jobs, low control at and over work, and limited possibilities for changing to a less physically demanding job (Nylén \& Torgén, 2002; Bengtsson \& Nilsson, 2004; Nilsson, 2006; Nilsson, 2017; Nilsson \& Nilsson, 2017). Consequently, the fraction of women who feels pushed into voluntary early retirement due to the combination of musculoskeletal health problems and high physical job demands is higher than among men.

Older workers, who experience high degree of social participation and meaningful self-rewarding tasks, extend their working life participation, despite high demands and chronical health problems (Nilsson, 2016a; Nilsson, 2012). Many also stated a good physical and mental health because of their possibility to have a work and engagement in old age. However, a study performed in France indicated that early retirement may be associated with self-reported improvement of health, particularly in low-skilled jobs with high mental or physical work demands (Sjösten et al., 2010, Westerlund et al., 2010). Another study in Finland indicated that mental fatigue and sleep disturbances decreased after retirement (Laaksonen et al., 2012). Similar observations have been made among low-skilled Danish workers in health care (unpublished). On the other hand, people with high professional status often experience decreased mental health after retirement (Stattin, 2005; Jokela et al., 2010). A large Danish register-based study did not find a reduced risk of treatment for depression after retirement (Olesen et al., 2015). A similar large Danish register-based study indicates that labour market exit is associated with a moderately increased risk of coronary infarction (Olesen et al., 2014). However, Syse et 
al., (2015) who investigated changes in health status and behaviours associated with retirement, found that retirees, compared with workers, were more likely to report improvements in mental health and less likely to report mental health deteriorations. Retirees were also more likely to increase physical activity and lose weight.

In Iceland there has been a nearly steady increase in number of people receiving disability pension over the past 25 years, the increase being primarily related to mental and musculoskeletal disorders (Thorlacius et al., 2010). At the same time the prevalence of mental disorders has not been known to increase in the earlier part of this period when using identical methods for the assessment (Helgason et al., 2004). How this should be interpreted is a dilemma, but in light of no significant change in any age group for work participation, it is difficult to explain why early exit to disability pension has increased. Most likely other social parameters are important.

\subsubsection{Socioeconomic conditions}

In addition to the social gradient in disability pensioning, included in the previous chapter (4.1.1.), several Nordic studies have shown that there is a strong social class gradient in early retirement in all Nordic countries (Midtsundstad 2001, 2002a, b, 2003, 2005a,b, 2006; Lund \& Villadsen, 2005; Lund et al., 2006; Larsen et al., 2011; Welin \& Wilhelmsen, 2013; Hermansen, 2011; Nielsen 2014, 2017; Midtsundstad \& Nielsen, 2013, 2014a; Arbejderbevægelsens Erhvervsråd 2016b; Kadefors et al., 2014, 2017; Nilsson, 2006; Nilsson et al., 2016a).

According to a Danish survey, $30 \%$ of older workers being $60+$ years state that they continue to work because they cannot afford to retire (Nielsen Breidahl in Andersen \& Jensen, 2011). In a Norwegian survey among local governmental employees one out of four stated that they continued to work after reaching the retirement age (62), because they could not manage economically without the extra money from paid work (Midtsundstad \& Nielsen, 2013). This reasoning was especially common among women and low skilled workers. Other studies have found that those commonly working up to age 67 or longer in Norway are low skilled workers and academician (Midtsundstad, 2002, 2005).

A Danish survey from 2008 among 3,122 workers age 50-59 years, reveals that economic incentives may postpone retirement. Approximately $40 \%$ states that they will postpone retirement if they can get reduced work hours with full or partial compensation, and $34 \%$ would postpone retirement if they can get a reduction in income tax (Thorsen et al., 2011).

\subsubsection{Personal attitudes and motivation to work}

A study of retirement processes in eight different Norwegian industries in 2009-2010 (case studies), found that older workers often stressed the importance of well-being at work for their retirement decision. But well-being at work seemed to have different meanings according to amount of education: while care workers and industrial workers stressed that they enjoyed being at work (the social aspect), engineers and executive officers enjoyed the work itself, their work task and other aspects of their work (personal- 
development) (Midtsundstad \& Bogen, 2011a-c). Likewise, a cohort study among governmental employees and retirees in Norway (Midtsundstad 2005a-b) found that whether one still found the work and job task interesting and rewarding was more important for the retirement decision for white collar than for blue collar workers. For blue collar workers, self-rated health problems and work capacity and number of years in employment were the most important factors (ibid.). Similar patterns were observed when analysing data from cohort studies among private sector employees and retirees (Midtsundstad, 2002a) and municipality employees and retirees (Midtsundstad \& Nielsen, 2014a). Both studies were based on survey data (telephone interviews) with 1,500 individuals in the private sector and 3,200 individuals in the municipality sector. All the participants were employed at age 60 (in private sector) and at age 55 (in the municipality sector) and interviewed when they were from 58 to 69 years old.

Similarly, Swedish studies indicate that people who see their work as an important part of their identity are more willing to continue working after age 65 (Stattin 2005, Nilsson 2005b, Nilsson 2011, 2012, 2017b). Managers' support may be an important Stay factor, prolonging working life (Nilsson 2011, 2016b; Midtsundstad 2005a, Midtsundstad \& Nielsen, 2013).

A Danish survey from 2006/2007 among older workers, who were still working after age 60 , found Stay factors to be of particular importance. A large fraction of workers expressed that they continued to work due to good social relations to leader $(69 \%)$ and colleagues ( $75 \%$ ). A very high fraction ( $84 \%$ ) also expressed that they continued to work because they found the work interesting and fulfilling. On the other hand, Stuck factors were less important, and only $30 \%$ expressed that they continued to work because they could not afford to retire (Nielsen Breidahl in Andersen \& Jensen, 2011). The study revealed that workers who decided to enter voluntary early retirement - in comparison with older workers who continued working - had less responsibilities and less autonomy at work, and more frequently experienced stress, fatigue and strenuous work. Midtsundstad \& Nielsen (2014a) also found that good social relations to the nearest leader significantly increased the probability of municipality employees to delay retirement and continue working after age 62 . The same was found in a cohort study among governmental sector employees in 2002/2003 (Midtsundstad, 2005a,b). In addition, the study showed that those who had experienced age-discrimination retired earlier than those with no such experiences.

\subsection{The meso (domestic or workplace) level}

\subsubsection{Domestic factors}

In the Nordic countries (except Finland and marginally in Sweden), women retire earlier than men (see section 2.1).

In Denmark, Norway and Sweden women living alone tended to retire later than women living with a partner (Ahlberg et al., 2001; Nylén \& Torgén, 2002; Midtsundstad, 2002; Larsen \& Pedersen, 2013; Midtsundstad \& Nielsen, 2013; Nilsson 
2006, 2015, 2012, 2017b), whereas Norwegian men living alone tended to retire earlier (Midtsundstad, 2002).

Danish men living with a spouse with equal or higher age, retired earlier than men living with a younger spouse (Jørgensen et al., 2005). In Sweden, having a retired spouse influenced early retirement more often among women (10\%) than among men (3\%) (Nordenmark \& Stattin, 2009; Nilsson 2015), and Swedish men tended to postpone retirement if they had a spouse still working (Welin \& Wilhelmsen, 2013). Similarly, in Norway, women seemed to have a much stronger response to their spouses' characteristics than men (Jia, 2005a). However, the probability for men retiring early increased $10 \%$ if the spouse retired the same year (Bråthen \& Bakken, 2013).

In the Nordic countries, the importance of caring responsibilities (for elderly parents or other family members) for retirement has only been studied in some detail. A Norwegian study indicated that caring responsibilities were of limited or no importance for early retirement in general (Midtsundstad, 2009a,b). However, earlier multivariate analyses showed that having a sick partner or relative, increased the probability of early retirement, and one out of four women over 55 years worked part-time due to caring responsibilities (Midtsundstad, 2002; Midtsundstad, 2005b). Among older employees with one or both parents being alive, $70 \%$ experienced that caring responsibilities affected their working life (Gautun \& Hagen, 2010). However, caring responsibilities did not lead to early retirement, but increased the likelihood of sickness absence (Fevang et al., 2009). In Sweden, $4-5 \%$ of women and $1-2 \%$ of men aged $50-74$ years reported that they worked fewer hours the year before retirement due to caring responsibilities.

A Norwegian study of the retirement pattern of couples, found that a dynamic model, taking only measures of economic incentives (wage and pension benefits) into account, had a satisfactory fit with the observed retirement pattern (Jia, 2005b). This study may indicate that other factors, which may influence the decision to retire, may in fact be of limited importance. However, this is probably too simplistic, since it tends to rule out the importance of well-known strong Push factors (the combination of ill health and strenuous work or the excluding effects of long-term unemployment), which may be closely linked to personal economy.

A survey in 2010 among 5,140 occupationally active Danes age 55-70 years, showed that every third of the persons, who have entered voluntary early pension, stated the cause to be a wish to give family and leisure time activities higher priority (Larsen et al., 2011). Similar results were obtained in Sweden (Bengtsson \& Nilsson, 2004; Nilsson 2015, 2017b; Nylén \& Torgén, 2002). Wish for more leisure time is also the most important reason to enter voluntary early retirement stated by early retirees in Norway (Midtsundstad, 2002; Midtsundstad, 2005a-b; Midtsundstad \& Nielsen, 2014). However, the retirees in these studies also underscored their health problems and their strenuous work as important reasons for their withdrawal from the labour market. The emphasis on more leisure time may then (as well) be interpreted as an opportunity to be released from strenuous work task and/or an opportunity to rest because of health problems (discussed in Midtsundstad, 2002a). Furthermore, in an analysis of local governmental sector employees' retirement behaviour in Norway, Midtsundstad (2009) found that relatively few emphasize more time with children and grandchildren 
as an important reason for retiring early (Midtsundstad, 2009). More time with one's partner/spouse, however, seemed to be an important factor.

\subsubsection{Workplace factors}

See chapter 5

\subsection{The macro (societal) level}

\subsubsection{The labour market}

It should be noticed that the labour market participation of older workers in the Nordic countries is high compared with the rest of OECD (see section 2.1) (Jensen \& Madsen in Jensen \& Rostgaard, 2015).

In the Nordic countries, employers are in general reluctant to hire older workers (e.g. 55+ years) (Dalen, 2013; Barslund, 2015), and difficulties to find (an equal good) job with a new employer tend to reduce the labour market mobility of older workers (Tofteng et al., 2016; Tofteng (ed.), 2016; Lien, 2014; Work and Health 2014). In Denmark, the fraction of older workers (age 55-64 years) who in 2014 had changed workplace during the last years, was $5.9 \%$ among men and $4.2 \%$ among women. This was far below the average mobility of the workforce in general (13.7\%) (Work and Health 2014). The possibilities for older workers to find a new job are far better in Norway and Iceland than in Sweden and Denmark (Furåker et al., 2014).

If access to retirement is restricted - through altered pension legislation and labour market regulation - this may not necessarily increase the fraction of older people being actively employed at the labour market. An important shortcoming relates to the opportunities for transfer between different social benefit schemes (e.g. unemployment, sickness absence, and disability schemes) (Belin et al., 2016). In theory, labor market regulations may increase transfer to different social benefit schemes, particularly for older people with low labour market mobility due to short education and/or health problems.

In Denmark, long-term unemployment is a strong Push factor, increasing the probability for early voluntary retirement (Borg, 2016). This does not seem to be the case in Norway (Halvorsen \& Tägtström, 2013). Six months after entering unemployment, $57 \%$ of unemployed Norwegians above the age of 60 has re-entered work (Myklebø, 2011). In Norway, loss of employment (in relation to company closure or downsizing) is instead strongly associated with disability pension, and for men, job loss more than doubled the risk of entering permanent disability (Bratberg et al., 2010). For women, decreasing unemployment rates are correlated with increasing numbers on disability and rehabilitation, indicating that increased employment draws less healthy workers into the labour force (Andreassen \& Kornstad, 2010). In Iceland, unemployment is a recognized factor for increased level of disability (Thorlacius \& Olafsson, 2008). 


\subsubsection{Pensions and social security legislation}

The international research literature have found that compensation rates, tax rules, statutory pension ages and other age limits, eligibility criteria etc. influence the timing of retirement.

The impact of pension and labour market policy on older workers attitudes was evaluated in an interesting cross-national study covering Denmark, Great Britain, Hungary, and Sweden (Hult \& Stattin, 2009). During the period 1997 (baseline) to 2005 (follow up) all countries implemented policies to increase labour market participation of older people, and the labour market participation of people age $55^{+}$has increased in all countries. The authors suggested that this increase may reflect that the implemented legislations enhanced Stuck-factors, which may to some extent have forced older workers to continue working. However, the authors argued that a positive attitude to work in general ("employment commitment") and to the specific workplace ("organisational commitment") may be of particular interest, since positive attitudes are important for productivity, quality and health. However, the authors concluded that with few and minor exceptions, the employment commitment and the organisational commitment were not increased during the period (Hult \& Stattin, 2009). From a Nordic point of view, it may be worth noticing that employment commitment actually decreased statistically significantly among Swedish men and Danish women in the age group 45-53 years. The authors emphasized that employment commitment was in general high in Denmark and Sweden and low in Great Britain and Hungary.

In Denmark, a questionnaire based survey in 2010 showed that the age limit for entering voluntary early pension (6o years in 2010) determined to a higher extent when employees age 55-59 years expected to retire than the age limit for ordinary pension (65 years) (Larsen et al., 2011). Well above half of the employees expected to retire before the ordinary state pension age (Larsen et al., 2011; Thorsen et al., 2011), and this is in good agreement with the fact that the effective retirement age is well below the ordinary state pension age in Denmark (see section 2.1). These results clearly indicate that an early-exit culture still prevail in Denmark.

Vestad (2013) has estimated the labour supply effects of the Norwegian early retirement programme AFP in the 1990s, using detailed administrative data to characterise full paths towards retirement and account for substitution from other exit routes, such as unemployment and disability insurance. He found that the reduction in the lower age limit for early retirement during the 1990 s reduced the labour market participation of those aged 62-64. According to him more than two out of three pensioners would still be working at the age of $6_{3}$, had the age limit been 64 rather than 62 . Hence, although successful in creating a more dignified exit route for early leavers, the programme also generated substantial costs in terms of inducing others to retire earlier.

A Swedish register-based study among white collar workers could not find any effect of lifting the pension age of Swedish local government workers on the overall consumption of health care, nor on the risk of dying early. There was evidence of a reduction in diabetes-related hospitalizations and in the consumption of drugs to treat anxiety (Hagen, 2016). 
A very positive growth in employment has been noticeable among Norwegian workers aged 62-64 years, after the pension reform in 2011, and this applies for both women and men. The growth has been particularly strong for those with secondary education as their highest level of education, and was stronger in the private sector than in the public sector from 2011 to 2012. Furthermore, old-age pensioners aged between 62 and 66 continue working almost as much as they did prior to taking up their pension benefits. Of those combining work and the old-age pension, over 80 percent work at least 30 hours per week (Claus et al., 2014; Dahl \& Lien, 2013; Bråthen \& Bakken, 2013).

Hernæs et al. (2016) and Midtsundstad \& Nielsen (2014) compare changes in employment at before and after the pension reform in private sector companies with and without the new, flexible (actuarial neutral) AFP scheme and public sector companies with the old AFP scheme. Both find that the probability of being employed has increased more in private sector companies with new AFP than in public sector companies with old AFP, controlled for a range of other relevant factors. Hernæs et al. (2016) also find that the probability of being employed for those in private sector companies without AFP decreases over the period. The reason seems to be that they now have the possibility of drawing a flexible old-age pension from the National Insurance scheme from the age of 62. Previously (prior to 2011), they had to wait until the age of 67 .

Until 2011, Norway's National Insurance system provided benefits from the age of 67 , but with an earnings test for those aged $67-69$. Up to the 1 January $2008,40 \%$ of earnings exceeding a threshold were deducted from the public pension. The threshold was around one sixth of average full-time earnings up to the 1 January 2002, when it was doubled. Part of the ongoing pension reform is the complete elimination of the earnings test; it was abolished for those aged 67 from 2008, for those aged 68 from 2009 and for those aged 69 from 2010. In the current system there is no deferral, so the earnings test can be viewed as a "real" tax. Hernæs \& Jia (2009) analyse the changes in earnings following the reform implemented in 2002, which doubled the wage threshold for the earnings test, using administrative registers, spanning the years 1999-2003, covering many socioeconomic dimensions of the whole population and containing extensive information on employment and income. In broad terms, their analysis indicates a positive labour supply response to the earnings test reform. The impact of the earnings test was also confirmed by a difference-in-difference analysis of the reform. However, they find no clear evidence that the reform has increased labour market participation.

Brinch et al. (2012) have also studied two recent changes in incentives to work facing 67-69 year-old workers in Norway: an earnings test reform (which increases current earnings from work) and a pension system maturation (which increases pension accrual from work). Within a difference-in-differences framework, they exploit these changes to investigate the effects of economic incentives and find that the earnings test reform has significant effects, while the pension system maturation has no significant effects. The findings confirm that $67-69$ year-olds do adjust their work efforts when there are economic incentives but are only motivated to do so by incentives affecting their current income and not those affecting their future pension. 
The positive effect of changes to the old-age pension on employment rates among those aged 67 and above are also documented by Bråthen \& Grambo (2009). They find that the changes had an effect on older workers' labour market participation: the probability of a person aged 66 working at the age of 67 , increased by $4 \%$. However the effect varied with individual characteristic and industry.

There are also studies of the connection between retirement behaviour and labour market participation among employees aged $62+$ entitled to a labour market-based pension (occupational pension) or employees being offered bonuses for opting out of employment. In a study based on survey data from 1,474 employees and pensioners born in 1933, 1934 and 1935, Midtsundstad (2002a) found that entitlement to an occupational pension (defined benefit) increases the probability of early retirement, controlled for other important factors like sex, education level, occupational group (class), income, health and working capacity, seniority, working conditions etc. Moreover, being offered a bonus for opting out of employment also increases the probability of early retirement at age 62 (Midtsundstad, 2002a).

Furthermore, a study by Kostøl \& Mogstad (2013) shows that there is significant potential among younger disabled people to work if financial incentives are increased. The authors do not, however, find any effects of economic incentives among disabled people in the 50-61 age groups. This research is supported by Bråthen (2011). Based on data from the Norwegian labour force survey, he estimates that nearly 32,000 people receiving disability benefits would like to start working. But while $22 \%$ of the recipients in the age group 35-49 report willingness to work, the proportion among people above the age of 50 is only $9 \%$.

Studies on the impact of pension legislation on retirement behaviour have not been made in Iceland. 



\section{The working environment and work retention of older workers}

In the present report, we have taken a broad view on working conditions comprising both working environment factors, and human resource management (HRM) and organisational processes which may affect the decision to retire or extend work life.

\subsection{The fraction of labour market exit attributable to the working environment}

Labour market exit is caused by the complex interaction of a multitude of factors at the micro-, meso- and macro level, and it may be difficult to estimate the relative importance of the working environment.

One approach, which has been used in some Nordic studies, is to estimate the fraction of retirement which can be attributed to working environment exposures (the attributable fraction). This type of estimation is part of the biomedical research tradition, and adjustments are made for factors known to influence health (e.g. age, gender, life style, social gradient). However, in general, adjustments are not made for other factors which could influence retirement behaviour (e.g. access to different pension and social benefit schemes, other economic factors, attitudes of spouse, family and close friends etc.). Therefore, the estimates of attributable fractions may to some extent be hampered by residual confounding.

A Danish study estimated that high physical work demands were strong risk factors for disability retirement for both men (attributable fraction 21\%) and women (attributable fraction 34\%) (Labriola et al., 2009a). Another Danish study revealed that each of two psychosocial work factors - decision authority and variation - (after adjustment for ergonomic work environment exposures, age, smoking, and BMI) could explain $10-15 \%$ of the risk of disability retirement (Christensen et al., 2008). A Norwegian study, based on surveys by Statistics Norway 2006 and 2009 ( $N=6745,18$ 66 years), found that the estimated population risk for self-reported work disability, attributable to five psychosocial and eight mechanical (ergonomic) risks at work, was about $45 \%$, largest for standing (21\%) and monotonous work (19\%), for those exposed $3 / 4$ of the workday (Sterud, 2013). A Danish study on long-term sickness absence revealed that physical work demands (after adjustment for psychosocial factors, age, education, life style, and family factors) could explain $23-28 \%$ of the long-term sickness absence (Christensen et al., 2005). A similar study showed that seven psychosocial work factors together could explain $29 \%$ of long-term sickness absence in Denmark (Nielsen et al., 2006). Even though the health outcome in the last two Danish studies was not 
retirement behaviour, they may still be relevant, since long-term sickness absence has been shown to be strongly associated with subsequent early retirement (Borg, 2016).

A series of Norwegian studies have estimated the impact of the working environment on social inequality in retirement behaviour (Mehlum, 2013). One study used the large HUNT 1 survey (1984-86, N=35,000 employed men and women, 25-59 years), linked to the national disability register, to demonstrate that working conditions partly explained the social class inequality in disability retirement due to back pain 1987-93. Physically demanding work and poor general health had the largest impact (Hagen et al., 2002, 2006). Similarly, the Norwegian HUSK study 1997-99 ( $N=7,031,40-$ 45 years) demonstrated that work-related factors (particularly physical job demands and job control) could explain $25 \%$ of the social class difference in disability retirement by the end of 2004 (Haukenes et al., 2011). A recent Norwegian study on long-term sickness absence ( $\geq 40$ working days during 2010), based on a survey in 2009 by Statistics Norway $(\mathrm{N}=6,758)$ also showed that work-related mechanical and psychosocial factors explained $41-44 \%$ of the social gradient in men and $31-54 \%$ in women (Sterud \& Johannessen, 2014). In Iceland, there is lack of studies on the number of persons exiting the labour market due to the working environment.

\subsection{Work factors}

\subsubsection{Chemical work factors}

Even though many blue-collar workers are exposed to potentially health damaging chemicals, hardly any studies exist on possible associations between chemical exposures and early retirement.

A Norwegian study of different work environment predictors of disability pension was based on an 18-years follow up study of a sample of 5,749 respondents (age 40-42 years in 1988-89). Among the factors showing the strongest association with disability pension, was exhaust fumes (Støver et al., 2013). Another prospective Norwegian study $(\mathrm{N}=1,152,20-55$ years in 1990) on predictors for low back disability pension during 12year follow-up, showed that an index composed of physically demanding work, noise, air pollution, draft, bad work postures, and high work speed was a statistically significant predictor (Brage et al., 2007). However, the contribution of air pollution to the hazard was not explained.

In a Danish study with baseline questionnaire-based data obtained in the Danish Work Environment Cohort Study (DWECS) in 1990, 1995 and 2000, 8,337 persons in the working population were followed in registers until the end of 2006 to record transitions to disability pension. Among women, occupational skin contact with cleaning agents or disinfectants (after adjustment for age, smoking status and BMI) was a risk factor for disability pension (attributable fraction 11\%) (Feveile et al., 2009). However, it may be argued that skin contact with cleaning agents or disinfectant may simply be a proxy measure of being a cleaner, and this profession is also characterized by a very high physical workload which may cause health problems. 
In a Norwegian representative study (Alfonso et al., 2016), based on a survey in 2009 by Statistics Norway $(N=8,566)$, physician-certified long-term sick leave ( $\geq 16$ days) was predicted by occupational skin exposure to cleaning products and waste among men, and occupational skin exposure to water among women. Analyses were adjusted for psychosocial and mechanical occupational exposures and education. The estimated population attributable risk for occupational skin exposure was $14.5 \%$.

A recent Norwegian report calculated work-related mortality in Norway and concluded there were more than 500 deaths per year due to work-related diseases, mainly lung cancer, mesothelioma and chronic obstructive lung diseases (Hem et al., 2016), mostly caused by chemical exposure, dust or radiation. Since these exposures may cause severe diseases, they may probably also lead to work disability and shortened working life for individuals who get ill.

No studies have been made in Iceland on possible associations between chemical exposures and early retirement.

\subsubsection{Occupational accidents}

Occupational accidents are strong predictors of disability pension (Lund \& Bjerkedal, 2001; Tüchsen et al., 2009; Arbejderbevægelsens Erhvervsråd, 2016a), and occupational accidents are most incident among blue collar workers (Lund \& Bjerkedal, 2001; Work and Health 2014). In Iceland, the social consequences of occupational accidents have been documented among seamen in particular (Sigvaldason et al., 2010).

In Sweden, older workers had most of the occupational accidents, and among older blue-collar workers, poor physical working environment, causing accidents and injuries, increased the risk of early retirement (Hult et al., 2010; Hult \& Stattin, 2009, Nilsson et al., 2010; Nilsson \& Pinzke, 2012; Pinzke et al., 2014; Nilsson 2016b). Similarly, fatal occupational accidents are most incident among older workers (particularly farmers) in Norway (NOA 2015). In Denmark and Iceland this did not seem to be the case. The Danish working environment survey "Work and Health 2014" revealed that the proportion of workers, who had experienced occupational accidents during the last 12 months, was highest in the younger age groups and lowest in the oldest age group 5564 years (Work and health 2014). Additional analyses in Work and Health 2014 revealed that this probably does not reflect differences in occupations between the age groups, since the decrease in occupational accidents by age is observed within practically all industries. Particularly in the building and construction industry, the age differences are profound. A similar gradient of decreasing incidence of accidents with age has been reported in the building and construction industry in Norway, and this is stated to be partly due to lack of safety training and competence among young construction workers (Winge et al., 2015). In Iceland, the online occupational accident registry (http://vefkerfi/slysaskraning/t $\% \mathrm{C}_{3} \% \mathrm{~B} 6$ lfr\% $\% \mathrm{C}_{3} \% \mathrm{~A} 6 \% \mathrm{C}_{3} \% \mathrm{Boi}$.aspx) clearly shows a dominance of occupational accidents among young people in the age group 19 to 29 years, with the number of accidents tapering off with age. However, among women, serious accidents resulting in broken bones are most frequent in the age group from 60 to 69 years of age. 
A recent Swedish review stated the lack of injury prevention activities to older employees (Nilsson, 2016b). Farming is one of the most dangerous occupations, with high rates of occupational mortality, but only three evaluated prevention projects have been scientifically published worldwide, and none in the Nordic countries.

No explanations of the differences between Sweden and the other Nordic countries have been published. However, it could be due to a healthy worker effect because older workers who encounter an accident seem to disappear into retirement (Nilsson et al., 2010; Nilsson et al., 2016a). An alternative explanation is suggested in a recent Danish Ph.D.-study, demonstrating that it is customary in the Danish construction industry to place the most strenuous - and probably also the most risky - job tasks in the hands of the employees with the lowest status in the social hierarchy, i.e. apprentices, newly employed workers and immigrant workers (Ajslev, 2015). Since social standing at the workplace is linked to seniority, it may be speculated that older workers in Denmark regardless of the type of occupation - are given job tasks with lower risk of occupational accidents simply because of their seniority. A competing explanation may be that older and more experienced workers work more safely. This would perhaps be similar to the observation that older people drive car more safely and have less traffic accidents than younger drivers (Meng, 2013).

\subsubsection{Physical work factors}

Vibrations and noise

A Danish study, using DWECS data 1990-2000 (total of 8,337 persons in the working population) and register-based follow up until end of 2006 to record transitions to disability pension, demonstrated that whole-body vibrations were associated with increased risk of disability pension, after adjustment for age, smoking habits, BMI, physical job demands and awkward work postures (Tüchsen et al., 2010). Similarly, a Norwegian study of a cohort of the general working population $(6,745$ respondents age 18-66 years), based on surveys by Statistics Norway 2006 and 2009, demonstrated a statistically significant association between whole-body vibrations and exit to work disability, after adjustment for relevant possible confounders (Sterud, 2013). A statistically significant association between vibrations and disability pension was also demonstrated in a Norwegian 18-years follow up study of a sample of 5,749 respondents (age 40-42 years in 1988-89) (Støver et al., 2013).

A recent study among 107 teachers from 10 public schools in Denmark, revealed that working in classrooms with poor acoustics (long reverberation times) was associated with increased intention to quit, low job satisfaction, and lack of energy after work. In this study, the measurements of classroom acoustics were blinded to the teachers (Persson et al., 2013; Kristiansen et al., 2013). A Norwegian study ( $N=1,152$, 20-55 years in 1990) on predictors for low back disability pension during 12-year followup, showed that an index composed of physically demanding work, noise, air pollution, draft, bad work postures, and high work speed was a statistically significant predictor (Brage et al., 2007). 
No information on the impact of vibrations and noise on early retirement are available from Iceland.

\subsubsection{Strenuous work - high physical work demands}

High physical work demands, as well as perceived inability to sustain the physical exposures at the workplace, have repeatedly been shown to be a Push-factor contributing to early retirement in all Nordic countries.

A Danish study using DWECS data 1990-2000 (8,337 employees) and registerbased follow up until end of 2006, revealed that ergonomic work exposures (physically demanding work, working with hands lifted and repetitive work) were strong risk factors for disability pension among both men (attributable fraction 21\%) and women (attributable fraction 34\%) (Labriola et al., 2009a). Similarly, a seven years follow-up study with baseline information from year 2000 on socio-demographics, lifestyle, depressive symptoms and work demands ( 5,785 employed persons, aged 40 and 50 years) showed that symptoms of depression, as well as high physical work demands, were risk factor for disability pension after adjustment for a series of relevant covariates (Thielen et al., 2009; Thielen et al., 2013). A Norwegian study used the large HUNT 1 survey (1984-86, $\mathrm{N}=35,000$ employed men and women, $25-59$ years), to demonstrate that physically demanding work was a strong risk factors for disability retirement due to back pain 1987-93 (OR = 4.1) (Hagen et al., 2002, 2006). Another Norwegian study, based on the HUSK study 1997-99 ( $N=7031,40-45$ years), showed that especially high physical work demands and low job control were risk factors for disability retirement by the end of 2004 (Haukenes et al., 2014). A large prospective study in Norway, based on data from HUNT1 (1984-86), with 10 years follow up (62,369 participants), demonstrated that high physical work demands increased the risk of disability retirement between $40 \%$ and $55 \%$ (Krokstad et al., 2002). A recent Norwegian study (Emberland et al., 2017), using questionnaire data from 13,012 employees in 96 companies, linked with disability registry data, with median follow-up time 5.8 years, found that high physical workload nearly doubled the risk of disability pension, compared to having low physical workload. A Norwegian study of risk factors for selfreported work disability among 6,745 participants (age 18-66 years), found neck flexion, prolonged standing, whole-body vibration, and heavy physical work demands to be significant risk factors (Sterud, 2013). A similar study ( $N=5,749,40-42$ years in 1988-89) found heavy lifting to be a risk factor for disability pension during 18-years follow-up (Støver et al., 2013). Finally, Norwegian studies on causes of disability retirement due to osteoarthritis (Holte et al., 2000a,b), rheumatoid arthritis (Holte et al., 2001) and soft tissue arthritis (Holte et al., 2002), based on national census (1970 and 1980) and disability registry data, demonstrated that manual work was a strong risk factor, and the authors suggested that difficulties in adjusting the manual work demands to the physical capacity had key impact. A study ( $N=8,333,30-45$ years in 2000-01) found that heavy physical work increased the risk of long-term musculoskeletal sickness absence (>8 weeks) during 5-year follow-up (Foss et al., 2011). 
In Sweden, the age group 56-64 years is approximately one-fourth of the workforce, but they account for more than one third of the long sick leave cases, mostly caused by inability to perform physically demanding work, injuries and illnesses (AFA 2015). The risk of early retirement was increased by high physical demands in the work environment, poor physical working environment with high load, demanding or poorly designed working conditions causing exhaustion, accidents and injuries (Hult et al., 2010; Hult \& Stattin, 2009; Nilsson 2006, 2016a, 2016c, 2017b, 2017c; Nilsson \& Nilsson, $2017 \mathrm{~b}$ ). In addition, older people generally need longer recovery after illness and injury (Nilsson et al., 2010). A previous study in Sweden, revealed that perceived inability to sustain exposures at the workplace, reduced the willingness to late retirement, particularly among those with occupations in branches with high physical work load, such as health care and manufacturing, but also in education (Ahlberg et al., 2001). This is in agreement with a Danish study based on data from a survey in 2006. The study revealed that self-reported health problems due to work-related physical exhaustion were profoundly more frequent among persons age 60-64 years on voluntary early pension (16.2\%) than among persons in the same age group but still working (7.6\%) (Høgelund \& Thomsen, 2011). This is in agreement with a new Danish study showing that among older persons age 6o-64, who have entered voluntary early retirement, $38 \%$ had physically strenuous work whereas the fraction was only $11 \%$ among older persons age $60-64$, who continued to work. Similarly, $26 \%$ of older persons who had entered voluntary early retirement stated to be tired or exhausted after a working day, whereas this was only $16 \%$ of older persons, who continued working (Arbejderbevægelsens Erhvervsråd, 2016b). Perceived work ability may be considered a measure of perceived ability to sustain the exposures at work. In a Danish study, perceived work ability was measured using a single item on a 10-point scale. One point decrease in work ability was associated with $33 \%$ increased risk of early retirement and 15\% increased risk of long-term sickness absence (Sell 2009).

A recent Swedish study (Kadefors et al., 2014, 2017), estimated the work life expectancy (the expected years of being at work taking years lost to sickness absence and early retirement into account). The jobs with high risk of reduced work life expectancy due to early exit also stood out as high risk jobs with respect to physical work exposures (Arbetsmiljöverket, 2012).

In Norway, many blue-collar workers who had retired early emphasised the importance of long working careers, heavy workloads, health problems and reduced working capacity (Midtsundstad, 2002a; Midtsundstad, 2005a,b). Likewise, the main reason for retiring early among Norwegian low skilled health care workers is also selfreported health problems and reduced working capacity as well as heavy workloads; especially a psychical and stressful work situation (Midtsundstad \& Nielsen, 2014a).

A Norwegian register-based study investigated the impact of working conditions on individual retirement (1991-1999) for 18,847 employees (age 6o to 67) in 270 occupations (Blekesaune \& Solem, 2005). The study combined survey data for estimates of job strains (Job Exposure Matrices, JEMs, based on surveys by Statistics Norway 1987, 1991 and 1995), census data for occupations and income, and social insurance/security data for the transition from work to retirement. Data were analysed 
using logistic regression (competing risk) "duration" models. The study indicated that disability retirement was related to physical job strains.

Midtsundstad (2002) analysed Norwegian survey data covering 1,500 private sector employees and early retirees, using logistic regression, and showed that having a heavy workload increases the probability of drawing an AFP pension early, controlled for other relevant factors. She also found that many retirees themselves, especially bluecollar workers, relate their early retirement to heavy workloads, long working careers and, among other factors, to the company culture, i.e. that it was common at the workplace to retire at a certain age.

A Danish study used a questionnaire-based survey performed in 2000 among 365 employees in the age group 57-62 years and register-based follow up in 2004. The study revealed that two measures of strenuous work postures were significant predictors of voluntary early retirement after adjustment for a series of relevant confounders (Lund \& Villadsen, 2005; Lund et al., 2006).

A cohort study 2004-2006 among Danish eldercare workers $(N=7,025)$ showed that health problems and physical job demands were the main reasons for early retirement (Clausen et al., 2014a). In agreement, another prospective cohort study among Danish eldercare workers ( $N=2,444$ employees aged 45-57 years) revealed that high physical job strain as well as low organisational commitment, were associated with intention to retire very early (Sejbaek et al., 2013).

In Denmark, some job groups with academic or professional educations (e.g. school teachers and nurses) retire to voluntary early pension more frequently than the average for other workers with a similar level of education. A questionnaire-based study among nurses revealed that low self-rated health, high physical exertion during work, high work pace, and limited influence were predictors for voluntary early retirement (Friis et al., 2005).

\subsubsection{Psychosocial work factors}

Job control/autonomy/influence at work

A recent review and meta-analysis of 16 Nordic studies revealed a statistical significant causal link between job control and transition to disability pension (Knardahl et al., 2017).

In Sweden, increased job control seemed to be protective with respect to risk of transition to disability pension due to mental diagnoses (Samuelsson et al., 2013). Similarly, in Sweden low control over working hours was associated with expectancy of early exit (Bengtsson \& Nilsson, 2004; Nilsson 2006, 2012, 2015, 2016a, 2017a; Nylén \& Torgén, 2002).

A large prospective study in Norway with 10 years follow up (62,369 participants) demonstrated that low job control (survey data from HUNT1 1984-86) increased the risk of disability retirement between $29 \%$ and $40 \%$ during 10 years follow-up (Krokstad et al., 2002). Another large Norwegian prospective study $(\mathrm{N}=47,000)$, based on survey data from HUNT1 (1984-86) and HUNT2 (1995-97), and registry data, demonstrated low job autonomy, and low job satisfaction to be risk factors of disability retirement during an 11-year follow-up (Holte et al., 2000a). Similarly, a Norwegian study on 
retirement for 18,847 employees (age 60-67) in 270 occupations revealed that among men, low autonomy in job tasks (low control, based on a JEM, constructed from survey data) was related to transition to both disability retirement and non-disability retirement 1991-1999 (Blekesaune \& Solem, 2005). A recent Norwegian study (Emberland et al., 2017), based on questionnaire data from 13,012 employees in 96 companies, linked with disability registry data, found that high control over work intensity reduced the risk of disability pension, compared to low control. Another study $(\mathrm{N}=8,333,30-45$ years in 2000-01) found that low job control increased the risk of longterm musculoskeletal sickness absence ( $>8$ weeks) during 5-year follow-up among men (Foss et al., 2011). Midtsundstad \& Nielsen (2013) also found in a retrospective cohort study following 1,800 employees in the local governmental sector (from age 55), that lack of job autonomy and lack of a good relationship with middle management increased the probability of drawing an AFP pension as early as possible (at age 62), ceteris paribus. In a similar study (retrospective cohort study) among 1500 governmental sector employees (from age 55) Midtsundstad (2005b) found that low autonomy in job tasks (low control), poor relationship with middle manager, lack of challenging work tasks and age discrimination, increased the likelihood of early retirement with AFP (from age 62), controlled for a whole range of other factors (sex, educational level, working hours, tenure, income, wealth, civic status and spouse labour market status, self-rated health and work ability etc.).

A study on causes of gender differences in disability retirement in Norway $(9,195$ participants, age 40-60 in 2000-01, 4 years follow up) revealed that job control contributed significantly to the gender difference, but not shift work, nor physical work demands (Claussen \& Dalgaard, 2009).

A Danish study based on questionnaire data from 2008 (baseline) revealed that low influence at work is a significant predictor of voluntary early retirement after adjustment for a series of potential confounders (Thorsen et al., 2016).

A large Danish database with questionnaires from more than 40,000 respondents was used to show, that low influence at work predicted long-term sickness absence (Clausen et al., 2014C).

In Denmark, limited influence at work was a predictor contributing to voluntary early retirement among nurses (Friis et al., 2005).

\section{Job satisfaction}

A Danish study, using DWECS data 1990-2000 (8,337 employees) and registerbased follow up until end of 2006, showed a statistically significant association between low job satisfaction and exit to disability pension (after adjustment for age, smoking status and BMI) for women but not for men (Labriola et al., 2009b). Similar results with respect to risk of transition to disability pension during an 11-year follow-up were found in an earlier large prospective study in Norway $(\mathrm{N}=47,000)$, based on survey data from HUNT1 (1984-86) and HUNT2 (1995-97), and registry data (Holte et al., 2000a).

A Danish study linked data from questionnaires from 2008 (baseline) for 1876 employees age 56-64 years with register data on transition to voluntary early retirement within a four year follow-up period. Initial adjustment was made for a series 
of back ground variables (gender, socioeconomic status, marital status, physical workload, shift work and night work, part-time work etc.), and subsequently adjustment was made also for self-reported health and mental health. After these adjustments, 10 out of 16 different psychosocial working environment factors were significant predictors for early transition of voluntary early retirement: low job satisfaction, low influence, low possibility for competence development, low role clarity, age discrimination, low recognition from management, low organizational justice, low trust in management, low quality of leadership, and low predictability. After additional adjustment for "multiple testing", five predictors remained significant: low job satisfaction, low influence, low possibility for competence development, age discrimination, low recognition from management (Thorsen et al., 2016).

\section{Shift work}

A recent review and meta-analysis of 8 Nordic studies revealed a very limited and statistically insignificant link between shift work and transition to disability pension (Knardahl et al., 2017).

Using the DWECS data 1990-2000 (8,337 employees), it was demonstrated that among women, but not men, shift work was associated with increased risk of disability pension, after adjustment for age, general health, socioeconomic status, body mass index, smoking habits, and ergonomic exposures (Tüchsen et al., 2008).

In a Norwegian study, shift work did not cause gender differences in disability retirement (9,195 participants, age 40-60 in 2000-01, 4 years follow up) (Claussen \& Dalgaard, 2009). Another study ( $N=8,333,30-45$ years in 2000-01) found that having shift/night work increased the risk of long-term musculoskeletal sickness absence (>8 weeks) during 5-year follow-up among men (Foss et al., 2011).

\section{Psychological work demands}

Regarding the demand-control imbalance model a recent review and meta-analysis of 5 Nordic studies revealed a moderate evidence for a causal link between strain (high work demands and low control) and transition to disability pension. However, metaanalysis of 13 studies found very limited and statistically insignificant evidence for a link between work demands and transition to disability pension (Knardahl et al., 2017).

In Sweden, increased job demands were a risk factor of disability pension due to mental diagnoses (Samuelsson et al., 2013).

A Norwegian study on retirement for 18,847 employees (age 6o-67) in 270 occupations, revealed that, for both genders, psychological job stress (high demands, based on JEM) was related to transition to non-disability retirement 1991-99 (Blekesaune \& Solem, 2005).

A Large Danish study based on questionnaires from more than 40,000 respondents aimed to clarify if the demand-resource model could explain associations between psychosocial working environment and transition to disability pension. Quantitative demands comprised of high work speed and time pressure, and resources were influence at work and quality of leadership. The study revealed that the combination of low quality of leadership and high quantitative demands was the strongest psychosocial predictor of 
transition to disability pension, and low influence at work also predicted transition to disability pension (Clausen et al., 2014b). The same data was used to show that low influence at work, as well as low quality of leadership, predicted long-term sickness absence, and also that lack of these resources at work was a stronger predictor for longterm sickness absence than quantitative demands at work (Clausen et al., 2014C). Similarly, a Danish questionnaire-based survey among 5,140 employees aged 55-70 years in 2010, revealed that approximately $25 \%$ of those who had entered voluntary early pension, stated the cause to be exclusively related to the work, particularly high quantitative demands (high work pace and tight time schedules) (Larsen et al., 2011). This is in agreement with an earlier study showing that high quantitative demands were associated with intention of early retirement (Larsen, 2008).

However, a Norwegian study, based on surveys by Statistics Norway 2006 and 2009, did not find high psychological work demands to be risk factors for transition to self-reported work disability (Sterud, 2013). This is in agreement with the Danish study based on baseline data from 2008, showing that high quantitative demands (high work speed and time pressure), as well as high emotional demands, were not significant predictors for voluntary early retirement (Thorsen et al., 2016). It seems reasonable to suggest that high quantitative demands are perceived a problem particularly by persons who have reduced work capacity due to health problems. In agreement, a Danish study of 7,025 health care workers revealed that health problems and high quantitative demands were the main causes for transition to voluntary early retirement (Clausen et al., 2014a). It may be that the adjustment for health problems in the study by Thorsen et al. (2016) has partly reduced the effect of quantitative demands.

\section{Leadership support}

God relations to nearest leader may be of importance for all employees across age, gender, job type and education. A Norwegian study of risk factors for self-reported work disability among 6,745 participants (age 18-66 years), based on surveys by Statistics Norway 2006 and 2009, found low level of supportive leadership, and monotonous work to be significant risk factors, but not high physiological work demands, low job control, and bullying/harassment (Sterud, 2013). Midtsundstad \& Nielsen (2013) study, based on survey among older workers and retirees in the municipality sector $(\mathrm{N}=1,800)$, also found that lack of a good relationship with middle management increased the probability of drawing an AFP pension as early as possible (at age 62), controlled for other relevant factors. The same was found in a similar retrospective cohort study among 1500 governmental sector employees (Midtsundstad, 2005b).

A Danish study based on questionnaire data from 2008 (baseline), revealed that five different measures of relations between nearest leader and employees were significant predictors of voluntary early retirement: low recognition from management, low quality of leadership, low trust in management, low predictability, and low organizational justice. The analyses were adjusted for a series of potential confounders (Thorsen et al., 2016). This was in agreement with a Danish study among employees still working after the age of 60 years even though most of them could take early voluntary retirement. A large fraction of the employees expressed in $2006 / 2007$ that they continued working because 
of good relation to nearest leader $(69 \%)$ and colleagues (75\%) (Nielsen Breidahl in Andersen \& Jensen 2011). In agreement, a Danish study showed that low quality of leadership predicted long-term sickness absence (Clausen et al., 2014c). However, an earlier Danish study did not find low quality of leadership to be a predictor for transition to voluntary early retirement (Lund \& Villadsen, 2005), and two studies found that predictability was not significantly associated with voluntary early retirement (Lund \& Villadsen, 2005; Selbaek et al., 2013).

Swedish studies found that poor social support at work was correlated with selfreported expectancy of early exit (Ahlberg et al., 2001; Nilsson 2005b, 2006, 2012, 2015, 2016a,b, 2017b; Nilsson et al., 2011).

A recent Norwegian study (Emberland et al., 2017), based on questionnaire data from 13,012 employees in 96 companies, linked with disability registry data, found that fair leadership reduced the risk of disability pension, while role conflict increase the risk. Another Norwegian study ( $\mathrm{N}=8,333,30-45$ years in 2000-01) found that poor support from superior had an independent and moderate effect on long-term psychiatric sickness absence (>8 weeks) during 5-year follow-up, and appeared to be mediated through mental distress (Foss et al., 2010). The same authors also found that poor support from superior also had an effect on long-term musculoskeletal sickness absence among women (Foss et al., 2011).

Poor colleague fellowship/support

Regarding the Demand-Control-Support model, Swedish studies found that poor social support at work was correlated with self-reported expectancy of early exit (Ahlberg et al., 2001, Nilsson 2005b, 2006, 2012, 2015, 2016a,b, 2017a,b).

A Norwegian study, based on 18-years follow up ( $N=5,749$, age $40-42$ years in 1988-89), showed poor colleague fellowship and fear of reorganisation to be risk factors for disability retirement (Støver et al., 2013).

A Danish survey from 2006/2007 among employees still working after the age of 60 years, revealed that $75 \%$ of the employees expressed that they continued working because of good relation to colleagues (75\%) (Nielsen Breidahl in Andersen \& Jensen, 2011). However, a Danish study based on questionnaire data from 2008 (baseline) did not find that relation to colleagues was significantly associated with voluntary early retirement (Thorsen et al., 2016).

Possibility for competence development

A Danish study based on questionnaire data from 2000 (3,318 employees) revealed a statistically significant causal link between low possibility for competence development and disability pension retirement (Lund \& Csonka, 2003). A Danish study based on questionnaire data from 2008 (baseline), revealed that low possibility for competence development was a significant predictor of voluntary early retirement after adjustment for a series of potential confounders (Thorsen et al., 2016). This was also stated in Swedish studies (Bengtsson \& Nilsson, 2004; Nilsson, 2005a,b, 2006, 2012, 2016a; Nilsson et al., 2011). In agreement, an earlier Danish study - using a questionnairebased survey performed in 2000 among 365 employees in the age group 57-62 years 
and register-based follow up in 2004 - revealed that low possibility for competence development was a significant predictor of voluntary early retirement after adjustment for a series of relevant confounders (Lund \& Villadsen, 2005; Lund et al., 2006).

A recent Norwegian study (Emberland et al., 2017), based on questionnaire data from 13,012 employees in 96 companies, linked with disability registry data, found that positive challenge in work reduced the risk of disability pension.

Organisational commitment

A comprehensive review prepared for the Nordic Council of Ministers in 2005 (in Danish) indicated that low organisational commitment, in particular, is related to intention to quit (Borg 2005) which in turn is highly correlated with early retirement (Borg, 2005; Solem et al., 2014). In agreement, a prospective cohort study among Danish eldercare workers ( $N=2,444$ employees aged 45-57 years) revealed that low organisational commitment was associated with very early retirement intention (Sejbaek et al., 2013).

Fear of reorganisation

Only one study on the impact of reorganisation has been found. A Norwegian study, based on 18-years follow up ( $N=5,749$, age 40-42 years in 1988-89), showed fear of reorganisation to be risk factors for disability retirement (Støver et al., 2013).

\section{Conflicts at work/bullying/harassment}

The Danish study - using a questionnaire-based survey performed in 2000 among 365 employees in the age group 57-62 years - revealed that high level of conflicts at work were significant predictors of voluntary early retirement, after adjustment for a series of relevant confounders (Lund \& Villadsen, 2005; Lund et al., 2006).

A questionnaire study of burn out in the public sector ( 1,814 persons) showed, not surprisingly, that burn out was associated with intention to retire early (Kristensen et al., 2005).

In Sweden, lack of integration in a workgroup, bullying and "scapegoats" increased the risk of early retirement (Andersson, 2008; Kreluka, 2009; Krekula, 2010; Nilsson 2006, 2012; Nilsson et al., 2011; Nilsson 2015, 2017a,c). In Denmark, bullying among health care workers was shown to be a risk factor for long-term sickness absence (Ortega et al., 2011), but the association between bullying and early retirement has not been studied.

A Norwegian study of risk factors for self-reported work disability among 6,745 participants (age 18-66 years), based on surveys by Statistics Norway 2006 and 2009, did not find bullying/harassment to be a significant risk factor ( $O R=1.52 \mathrm{~ns}$ ) (Sterud, 2013).

Psychosocial predictors for late retirement

Psychosocial predictors for (decision to) late retirement have been studied to some extent in the Nordic countries. A review from 2006 indicated that predictive factors for later retirement were feeling professional pride and recognition, engagement/ commitment, feeling of meaningfulness in the work, influence at work, and opportunities for development at work (Poulsen et al., 2006). The last three factors may 
be important for job satisfaction. Two other studies showed a significant association between high job satisfaction and late voluntary retirement (Jørgensen et al., 2005, Larsen 2008). A Danish survey 2006/2007 among employees still working after the age of 60 years, revealed that a large fraction of the employees expressed that they continued working because of good relation to nearest leader $(69 \%)$ and colleagues $(75 \%)$, and $84 \%$ expressed that they continued working because they experienced work as interesting and fulfilling (cognitive, emotional and socially) (Nielsen Breidahl in Andersen \& Jensen, 2011). In agreement, in Sweden, good psychosocial and physical work environment, moderate working pace and working time, feeling of competence and possibility for competence development were factors determining whether older workers believed they could extend their working life after state pension age (Nilsson, 2006, 2012, 2016a, 2017a, c; Nilsson et al., 2011,2016b). In addition, Swedish men who planned to work past 65 years, were found to be happier with their work and have more influence on their working conditions than men planning to retire earlier (Nilsson, 2012; Welin \& Wilhelmsen, 2013). A Norwegian study, based on survey data from 2002 to $2003(N=1,800)$, revealed that especially among managers and higher educated employees who continued working after the age of 62 , the main reasons for staying at work were that the job still was interesting and rewarding, that they did not have health problems and that their manager wanted them to stay longer (Midtsundstad, 2003).

\subsection{Human resource management (HRM) and organisational processes}

\subsubsection{Organisational changes and processes}

Organisational changes, including restructuring and downsizing, occur frequently in both private and public sectors. In Sweden, negative experiences of organisational changes at work were found to be associated with early exit (Ahlberg et al., 2001; Nilsson 2006, 2012, 2015, 2016a, 2017a, c; Nilsson et al., 2011, 2016c; Nylén \& Torgén, 2002).

In Norway, several studies also found that restructuring and downsizing increased the probability of sickness absence, early retirement and welfare dependency (Midtsundstad, 2002, 2005b; Lorentzen et al., 2006; Røed \& Fevang, 2007; Rege et al., 2009; Bratsberg et al., 2010). One study found that employers' attitudes to older workers changed rapidly during the economic crisis (2008-2009). In particular, the protection of older workers during downsizing (the seniority principle) gained less support within the first half year of the crisis; however, there was a return to the former high level of support within the next half year (Solem, 2012).

\subsubsection{Human resource management}

There is extensive research on HRM and interventions for prolonging working life among older workers in Norway (for an overview see Midtsundstad, 2015b). The types of interventions and the experiences of the older workers have been extensively studied 
through surveys and case studies (Midtsundstad 2015a). Through the agreement of a more inclusive working life (IWL agreement), focus has been placed on reducing sickness absence and the use of disability pensions, increasing the retirement age and ensuring the recruitment of people with impaired functioning capacity and other vulnerable groups to the employment market. The goal of the last agreement is to increase the years in employment for 50-year olds by 12 months from 2009 to 2018.

As a result of the IW-agreement an increasing share of Norwegian companies has incorporated old age policy measures into their personnel policy (Midtsundstad, 2014, 2015b; Hermansen \& Midtsundstad, 2015). The majority of Norwegian employers report that they take - and indeed insist on taking - social responsibility for keeping people in employment. However, that responsibility is largely limited to their own employees (Midtsundstad, 2008). In 2013 (Midtsundstad, 2014), 73\% of all Norwegian establishments with 10 or more employees had introduced measures to enable persons with a reduced working capacity to continue in employment. $54 \%$ reported to have programs preventing health problems and improving work ability, whereas $30 \%$ of the establishments promoted training, life-long learning, and career development for older employees past the age of 55 . Similarly, $37 \%$ reported to have pro-retention programs for older employees above the age of 62 . The most common initiatives offered to retain older workers in Norway are less strenuous work, rearrangement of work tasks, extra days off, shorter working hours without a proportionate wage reduction, and provision of additional bonuses to older employees who choose to continue working rather than retire. This was found to be the case in both 2005 and in 2013 (Midtsundstad, 2007, 2014).

Studies show that companies in which work is allocated to teams, making employees mutually dependent on each other to perform their work tasks, are less inclined to offer older employees flexible working time arrangements (Midtsundstad \& Bogen, 2011a; Nilsson 2017). However, the possibility of offering retention measures facilitating more flexibility, such as additional leave and phased retirement, do presumably increase with the size of the company, even if work is allocated to teams. Compared to a small staff, which might provide less flexibility for adjusting staff plans, a larger staff may provide more leeway for adjusting production. Offering retention measures may also be correlated with cyclical changes. Studies of Norwegian employers show that companies increase their retention efforts when faced with labour shortages (Midtsundstad 2005C, 2011). Furthermore, when experiencing economic hardship and the need for retrenchment, such as in the aftermath of a financial crisis, companies seem to be less inclined to retain their older workers (Solem, 2012). However, during a period of downsizing it may also be important to retain core employees, while looking for possibilities to reduce the overall staff size in order to cut costs. In other words, some older workers may be regarded as more valuable for the company than other workers, especially those holding what may be described as a "key competence" (Midtsundstad, 2011). Being committed to the goals of the IWAgreement also increases the likelihood of offering retention measures (Midtsundstad, 2011). Studies have also found that time associated with training new staff is correlated with efforts to retain older workers in Norway (Midtsundstad, 2005C, 2011). Thus, for 
companies where the training of new staff requires substantial time, retaining experienced workers will presumably be desirable.

In Norway, most studies of the effect of HR policies on ageing and different types of interventions are related to well-being at work, health, work ability and attitudes to retirement, and expected (self-reported) retirement behaviour. The measurable "effect" is mostly defined as the older workers' wishes for a late exit. However, qualitative studies of the relationship between work time reductions, extra days off, bonuses etc., and expected and actual retirement age, failed to find any clear indications of effects of such interventions, although highly appreciated by the older workers receiving them (Bogen \& Midtsundstad, 2007; Econ, 2009; Hilsen, 2009; Hilsen et al., 2009; Econ, 2010; Hilsen \& Salomon, 2010; Becken, 2011; Midtsundstad \& Bogen, 2011a-c; Reichborn-Kjennerud et al., 2011; Becken, 2012; Hilsen, 2012; Bogen \& Hilsen, 2013).

A retrospective cohort study among governmental sector employees and retirees, using logistic regression, however, found that access to a retention program (active ageing measures) reduced the probability of drawing an AFP pension early (age 62), controlled for other relevant factors (Midtsundstad, 2005b). The same was found in a similar survey study from 2012 among municipality sector employees and retirees (Midtsundstad \& Nielsen, 2013).

In addition, several studies, based on combined survey and register data (20012007/2010) have analysed the causal effect of work place interventions on sickness absence and retirement behaviour, using either a difference-in-differences approach or fixed effect analysis (Midtsundstad, Hermansen et al., 2012; Midtsundstad, Nielsen et al., 2012; Midtsundstad et al., 2013; Hermansen, 2014; Hermansen, 2015; Hermansen \& Midtsundstad, 2015; Midtsundstad \& Nielsen, 2014; Midtsundstad \& Nielsen, 2016; Nielsen \& Midtsundstad, 2016).

The study by Midtsundstad, Hermansen et al. (2012) did not find any general effect on older workers retirement behaviour of being offered a retentions programme in the period 2001-2007, neither did separate analyses of the effect of such intervention on retirement behaviour and sickness absence in the municipality sector (Midtsundstad, Nielsen et al., 2012). Hermansen (2014), who studied the separate effect of individual retention measures, based om data from 2000-2010, however, found that older workers who were offered extra days off, had a reduced probability of drawing an AFP pension early (at age 62-63); although being offered reduced working hours with some wage compensation, did not have any effect (Hermansen, 2015). Furthermore, Hermansen \& Midtsundstad (2015) found that being offered a retention bonus reduced the probability of drawing an AFP pension at age 62 and 63 . In other words, some, but not all Norwegian studies showed that some of the retention measures offered by Norwegian companies seem to have an impact on the retirement behaviour, at least for some groups of employees. The studies so far have, however, only looked at the effect on retirement at age $6_{2}$ and $6_{3}$, and not whether such measures could increase the total years in employment after age $62-63$ or the productivity among those above 62 years.

Research has shown that the causes of early retirement are complex and are generated by a number of different factors within, as well as, outside the workplace. One would therefore assume that in order to be effective, the initiatives and 
instruments launched to prevent early retirement need to vary between professions, industries, and sectors. In Norway today, however, they do not. The options and the allocation criteria are surprisingly similar across industries and enterprises, despite the heterogeneity of needs, problems, and challenges (Bogen \& Midtsundstad, 2007; Midtsundstad \& Bogen, 2011, 2012, 2014; Bogen \& Hilsen, 2013). This may be one reason why active aging policies and the measures chosen by Norwegian companies are not necessarily effective in reducing early retirement. In addition, the costs of the measures offered may exceed the intended gains, as those who would continue working anyway also are entitled to the retention measures (Midtsundstad \& Bogen, 2011). The same argument goes for labor supply, that is, whether there will be any additional hours worked or not, as many of those who would otherwise work full-time now choose to work part-time.

However, in three different studies, based on a combination of survey and register data, investigating the effect of being offered different work place interventions to reduce sickness absence and disability, Midtsundstad \& Nielsen $(2014,2016)$ found that work-related measures to prevent injury and exhaustion did not reduce sickness absence probability or sickness absence duration per year among older workers, although such interventions reduced the likelihood of disability pensioning among workers past 50 (Midtsundstad \& Nielsen, 2016; Nielsen \& Midtsundstad, 2016). One reason may be that adjustments of working conditions make it easier for people with health problems or reduced working capacity to continue working, but at the same time, those with health problems have a higher probability of sickness absence, hence the probability of sickness absence increases.

A recent Norwegian study (Nielsen \& Knardahl, 2017), based on questionnaire data from 14,501 Norwegian employees from various occupations and industries, linked with disability registry data, found that a positive impression of human resource primacy (employees' perceptions of how the organization shows interests in its employees' welfare, happiness, and health) may reduce the risk of disability retirement.

In a Danish study Larsen (2008) investigated whether quality of work life measures differ in importance for male and female workers in their retirement planning, using samples of workers and retirees born in 1940 and 1945 drawn from Danish panel surveys in 1997 and 2002, merged with longitudinal register data. She found that male and female workers' retirement plans are affected differently by various aspects of the job, like job demands, increases in earnings, work hour satisfaction, opportunity to use skills on the job. The impact of earnings was largest for men, and only male workers considered job control and job security to be of importance. These gender differences suggest that men are more influenced than women by the quality of job dimensions in their retirement planning and, that an employer-initiated effort directed towards retaining older workers at the workplace will not necessarily be as effective for female as for male workers.

In Denmark no studies have been made on the direct effects of policies and actions for retention of older workers. However, indirect knowledge may be gained from a study, demonstrating that at workplaces, where the employees experience that efforts 
are made to retain older workers, the expected retirement age is much higher than at workplace, where the employees do not experiences such effort (Jakobsen et al., 2014).

In Denmark, a study among managers of 2,000 workplaces revealed that half of the workplaces stated to have a policy for retention of older workers. This was more frequent at public workplaces and at larger workplaces (Lederne, 2012). This is in agreement with a survey among older workers, in which nearly half also stated that, the workplace take action to retain older workers longer (Larsen \& Pedersen, 2016). A similar study revealed that $44 \%$ of older workers age $60-64$ years stated that the workplace takes action to extend work life for employees $60+$ years. In this study, the workplace actions were predominantly experienced by older workers who were placed high in the job hierarchy (Jakobsen et al., 2014). However, at a closer look only few workplaces had taken concrete measures to extend the working life of their older workers (Jensen \& Juul Møberg, 2012), and only $23 \%$ of Danish workers report that their workplace have measures to adapt the work conditions to older employees (Andersen et al., 2016). This is in agreement with results from a new survey in which $75 \%$ of workers age $55^{+}$years stated that the workplace did not offer actions to retain older workers, e.g. reduced work hours, reduced workload through altered work task initiative etc. (LO, 2016c). If workplace actions were offered, the actions most frequently tended to provide opportunities for stepping down, i.e. flexible work-hours, reduced weekly work-hours, more days on leave/holiday, and less demanding work tasks (Jensen \& Juul Møberg in Andersen \& Jensen, 2011; Lederne 2012; Jakobsen et al., 2014; LO 2016c). Despite the fact that poor working environment is a strong predictor for early retirement, workplaces have seldom taken action to extend the work life of older workers by improving their working environment, and improved ergonomics and development of new competences are rarely provided (Jakobsen et al., 2014; Thorsen et al., 2016).

A Danish survey among 5140 occupationally active Danes in the age group 55-70 years revealed that $15-20 \%$ of the respondents stated that their workplace had formal or informal rules about at which age retirement is expected, and many said that they expected to retire early because this was the rule at their workplace (Larsen et al., 2011). On the other hand, one in four in the age group 60-64 years, and one in eight in the age group 55-59 years, stated that they had a personal senior agreement with the workplace, clarifying the mutual expectation of when and how retirement shall take place (Larsen et al., 2011). Another Danish study showed that approximately half of the respondents (age 45-64 years) stated that a typical retirement age existed at their workplace. The typical retirement age at public workplace was in average 62 years, corresponding to the age limit of voluntary early retirement releasing a bonus, whereas 65 years - corresponding to the age limit of ordinary state pension - was the typical retirement age at private workplaces (Jakobsen et al., 2014).

\subsubsection{Age discrimination}

Several Nordic research reports address age discrimination, which may be an important Push factor. Age discrimination is the unjust or prejudicial treatment of people on the grounds of age and occurs when people in the ageing workforce (e.g. $55^{+}$years) as a 
group are attributed negative characteristics. Based on the Directive 2000/78/EC on equal treatment in employment, age discrimination has been illegal in all Nordic countries since 2004-2005, and its prevalence is hard to determine, although in all Nordic countries, many workers are of the opinion that it takes place. In Norway, about $4-5 \%$ of people age $50+$ indicated that they had been exposed to age discrimination in working life themselves. This figure was in agreement with the latest Eurobarometer survey showing that $5 \%$ of Europeans (EU27) (age $50+$ ) had experienced age discrimination (Eurobarometer 2015). In Denmark, 6\% had been subject to age discrimination, placing Denmark above the average for EU27 (Eurobarometer, 2015; Barslund, 2015).

\section{Negative stereotypical ideas}

In a Swedish public sector study, managers seemed to see both advantages and disadvantages of older staff (Bengtsson \& Nilsson, 2004; Nilsson 2007, 2011, 2017b). Although managers appreciated older employees for their rigor, skills and life experience, a majority of the managers also had negative stereotypical ideas of older employees being slower, less prone to change, worse educated and opposed to new technology (Nilsson, 2007, 2011,2017a). Although half of the managers said there were measures to adjust working conditions for older workers, fewer had implemented such measures Also in Norway, negative stereotyping of older workers is reported in several studies, (cf. Midtsundstad, 2005a, 2007; Midtsundstad \& Bogen, 2011; Dalen 2013, Furunes \& Mykletun, 2007; Furunes et al., 2011).

Jensen summarized a series of studies on managers' positive and negative stereotyping of older worker, see Table 4. (Jensen in Andersen \& Jensen, 2011). This is in general agreement with a study made among managers at 2,000 Danish workplaces (Lederne, 2012).

Table 4: Positive and negative stereotyping of older workers

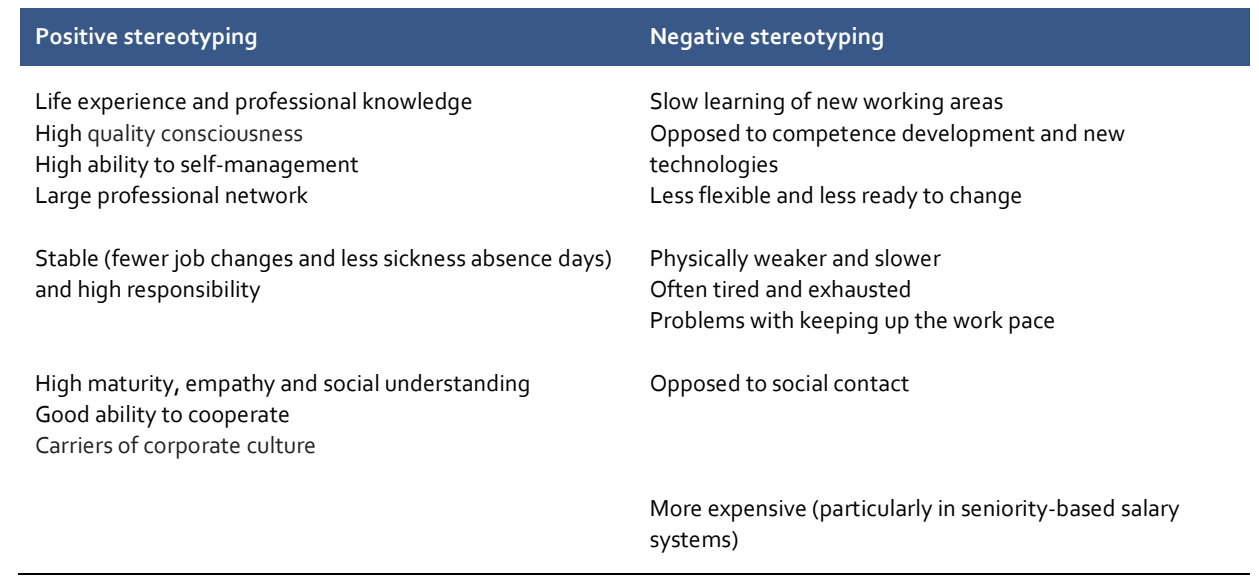

Source: Modified from Jensen (Chapter 4 in Andersen \& Jensen, 2011). 
Age discrimination and early retirement

In Denmark, Norway and Sweden age discrimination seems to be associated with early retirement (Krekula, 2009, 2010; Larsen et al., 2011; Nilsson 2006, 2012, 2015, 2016a; Nilsson et al., 2011; Thorsen et al., 2012, 2016; Midtsundstad, 2002; Midtsundstad \& Nielsen, 2013). Older employees seem to get less possibility to participate in new projects at the work place and to get competence development (Nilsson, 2005a,b, 2012). In a survey-based retrospective cohort study of early retirement among Norwegian government sector employees and early retirees, Midtsundstad (2005b) found that (self-reported) age discrimination at the workplace increased the probability of early retirement. Midtsundstad \& Nielsen (2014) also found in their analysis (logistic regression) of early retirement in the municipality sector in Norway, based on retrospective cohort data, that the probability of early retirement at age 62 increased for those who reported an unfavourable relation to their nearest leader. Several Norwegian studies also found that many individuals retire, when feeling their employer does not need them anymore. This was stated as one main reason for retiring early both among private at state sector employees (Midtsundstad. 2002, 2005a,b). The same was found in a similar study (retrospective cohort study) among 1,500 local governmental sector employees, followed from age 55. This in agreement with studies in Sweden, showing that men who felt unappreciated and women who felt superfluous at work preferred transition to early retirement (Soidre, 2005; Krekula, 2009, 2010; Nilsson 2005b, 2012, 2015, 2016; Nilsson et al., 2011). In Denmark, several employees stated that they intended to retire early because this was the rule of the workplace (Larsen et al., 2011). The same was found in two different retrospective cohort studies of early retirement behaviour in the governmental sector (Midtsundstad, 2005a) and in the private sector (Midtsundstad, 2002a) in Norway.

A Bachelor of Science thesis from University of Iceland was based on interviews with a small group of older individuals, who stated that they knew about age stigma but none of the interviewees had experienced such themselves. (2013 Porfinnsdottir Fordómar gagnvart miðaldra og eldra fólki á vinnumarkaði). In a report from Icelandic Ministry of Welfare from 2004, no evidence suggested that older workers on the job marked are received in a negative fashion. (https://www.velferdarraduneyti.is/media/acrobatskjol/Stada-midaldra-og-eldra-folks-a-vinnumarkadi.pdf).

Limited possibilities for unemployed senior citizens to obtain a new employment seem to be an important Push factor for early retirement. When an older person becomes unemployed, it may be impossible to get new employment, and the person feels forced to take early retirement. The cause of this is most likely age discrimination. Regarding opportunities for employment, the Eurobarometer 2015 survey revealed that $56 \%$ of adult Europeans believe that a job applicant's age, if over 55 , would be a major disadvantage. This is followed by a candidate's look, manner of dress or presentation (52\%), skin colour or ethnic origin $(46 \%)$, and a visible disability $(46 \%)$ (Eurobarometer, 2015).

This may be a particular large problem in Denmark, where job security is low, compared with the other Nordic countries. In 2003 , approximately $25 \%$ of the persons who were on voluntary early pension, retired from unemployment (Jørgensen et al., 
2005), and there is still a strong association between long-term unemployment and subsequent transition to voluntary early retirement (Borg, 2016).

In contrast to Denmark, unemployment benefit is used as a pathway to early retirement only to a very limited extent in Norway (OECD, 2011; Halvorsen \& Tägtström, 2013), and the retention rate (the rate at which firms retain older employees in their workforce), is especially high after the age of 6o, increasing from $65.2 \%$ in 2005 to 11 percent point higher in 2010. However, also in Norway, managers showed a less positive attitude towards "older" or "senior" applicants to jobs than to "young" and "experienced" applicants, and they hesitated to call in for job interview applicants in their late 505 (Solem, 2010; Solem \& Mykletun, 2009). Another Norwegian study concluded that older workers were among the least popular categories to recruit (Solem 2012).

Knowing that long-term unemployment is closely association with early retirement, it is of interest to know whether unemployment among older people may also be a result of age discrimination. In Denmark, the current fraction of the workforce being long-term unemployed is highest among young newly educated persons, and persons older than 55 years (Barslund, 2015). Among Danish older people $(60+$ years), who had entered voluntary early retirement, $21 \%$ reported that age discrimination played a large role during rounds of dismissals. In comparison, this was only reported by $9 \%$ of older people $(60+$ years), who were still active in the labour market (Andersen \& Jensen, 2011).

\subsection{The working environment of older workers}

Since the working environment has a considerable impact on early retirement particularly among blue collar workers with strenuous work and high work demands, it may be of interest to know whether - and if so how - the working environment of older workers differs from that of younger workers.

In a review of the literature, Solem (2010) found that physical and ergonomic work environments were often better among older workers than among younger workers. This may partly be due to selection (the healthy worker effect) and partly an effect of adaptions and shifts to less demanding jobs with age. The review found that older workers seemed to encounter fewer demands at work, but also received less support and feedback from their supervisor. In Sweden, it was reported that male blue-collar workers advanced to less physically straining jobs as they grew older, while women were less able to task-shift to less physically straining jobs. Instead, strenuous job tended to be a particularly strong Push factor for low-skilled women (Hogstedt \& Vingård 2011).

Detailed data on the current working environment is available from comprehensive national working environment surveillance programmes carried out in Denmark, Iceland, Norway, and Sweden. Selected data from the Danish "Work and Health 2014" survey, the Swedish "Arbetsmiljöundersökningen 2007 och 2009", the Norwegian Survey on Living Conditions (LKU) 2009 by Statistics Norway and the Icelandic Health and Well-being Survey 2012, and Occupational Accident Registry 2015 are presented in Appendix 1. For Denmark data for the age group 55-64 years are compared with data 
for the age group 25-54 years. The youngest group (18-24 years) has been excluded since this age group is highly atypical with respect to employment conditions, working hours per week etc. Data from Sweden are on workers age 50-64 years, data from Norway are on workers age 50-69 years, and data from Iceland are on workers age 5574 Years. For Denmark, Norway and Sweden, comparisons are made between all respondents in the survey and the group of blue collar workers. In Denmark, blue collar workers were defined by combining four of the ten main groups in DISCO o8: Work in agriculture, forestry and fishing; Crafts embossed work; Operator work, installation work and transportation work; Other types of manual work.

\subsection{Older workers (55-64 years) compared with younger workers (25-54 years) in Denmark}

The results of the Danish survey, comparing older workers with younger workers, are in agreement with the overall conclusion of the review by Solem (2010). The physical working environment of the older workers (55-64 years) in Denmark seems to be (slightly) better than that of younger workers (25-54 years), and this is more distinct for the blue collar workers. The results are in agreement with data from the European Working Condition Survey 2010 (Andersen et al., 2016). Older men and women work slightly fewer hours per week than the younger workers, and a smaller fraction of older men and women have night shifts. Here it may be of particular interest that older blue collar women actually have less work with night shift than all older women in average, and work with night shift among the older blue collar women is only about half of that of the younger blue collar women. The low mobility of older Danish workers may be noticed. The fraction of newly employed (within the last year) older workers is less than half of the fraction of newly employed younger workers for both men and women, indicating that older workers to a lesser extent seek new employments or to a lesser extent have opportunities for getting new employments.

In average, both younger and older workers in Denmark - for both men and women - report the work to be similarly physical strenuous, but looking only at the blue collar workers, the older workers report work to be slightly less strenuous than the younger workers. The older workers report less lifting, less work in awkward postures, less worktime with hand lifted above shoulders, less monotonous work, and less exposure to vibrations and loud noise. Looking only at the blue collar workers, these differences are more profound. This may indicate that older blue collar workers to some extent are giver less physically demanding work tasks than their younger counterparts. The older blue collar workers also report fewer accidents, the difference being most distinct for blue collar women. One possible explanation may be that the work tasks given to the older blue collar workers are both less physically demanding and pose less risk of accidents.

Considering the psychosocial working environment, the differences in Denmark between the two age groups are less pronounced. For both genders, similar work demands are reported ("work speed" and "sufficient time for work tasks"), and also similar levels of control and support from nearest leader. However, the older workers 
report fewer conflicts at work, they experience the same level of threats/violence as the younger workers, and the older workers report more often to be victims of bullying at work.

Interestingly, on average, the older workers report the same (high) work ability as the younger workers, and the older workers report a slightly better vitality and mental health.

Even though the older workers in general experience a better physical working environment, they do not to a higher extent report that their workplace takes particular consideration to employees with reduced work capacity. Consequently, they do not experience Danish workplaces to be inclusive.

\subsection{Comparison of working environment of older workers in Denmark, Norway, Sweden and Iceland}

Comparison of the data on working environment of older workers in Denmark, Norway, Sweden and Iceland (Appendix 1 ) is hampered by differences in the age group defining older workers. In addition, for some working environment factors, different phrasing of the questions and different scales are used, making comparison difficult. However, for many working environment factors, comparison seems feasible particularly between Denmark and Norway.

The gender differences between older blue collar men and women may be of importance. In Norway and Sweden older blue collar women tend to report less exposure to physically strenuous work (particularly low in Sweden), less exposure to heavy lifting (particularly low in Norway), and less exposure to work with hands lifted above shoulder than older blue collar men. In contrast, compared with older blue collar men, Danish older blue collar women report more exposure to strenuous work, approximately the same exposure to heavy lifting, more work in awkward postures, and more exposure to hands lifted above shoulder. In addition, Danish older blue collar women report far more exposure than men to work with monotonous movements, whereas blue collar women and men in Norway and Sweden report approximately the same exposure to monotonous movements. In all three countries, blue collar men report more exposure to vibrations and loud noise. The gender differences are most probably the result of men and women being occupied in different types of jobs.

Danish older workers report far more occupational accidents than older workers in Norway and Iceland (data not available for Sweden).

Danish and Swedish older workers (both men and women) report approximately the same, high exposure to work in awkward position, far exceeding the exposure of Norwegian older workers. Similarly, Danish and Swedish older workers are more exposed to work with hands lifted above shoulders than Norwegian older workers. Danish and Swedish older men are more exposed to vibrations and loud noise than Norwegian older men. On the other hand, Norwegian and Swedish older men are far more exposed to monotonous work than Danish men. Hence, the work of older workers in Norway seems to be less physically demanding than that of Danish and Swedish older workers, and this is particularly the case when comparing old blue collar men. Danish 
female blue collar workers report more exposure to awkward postures, and more work with hands lifted above shoulder than Norwegian and Swedish older blue collar women, and Danish and Norwegian older blue collar women report far more work with monotonous movements than Swedish older blue collar women. Consequently, the physical working environment of Danish older blue collar workers seems to be more demanding than that of Norwegian and Swedish older blue collar women. Altogether, the results indicate that the physical working environment of Norwegian blue collar workers is less demanding that that of Danish and Swedish blue collar workers. However, both women and men in Norway seem to have quite high exposure to monotonous work. Since the physical working environment appears to be most demanding in Denmark, reduction of exposures to physical working environment factors may be a particularly promising way to increase labour market retention of older blue collar workers in Denmark.

Work demands (high work speed) are higher in Denmark and Norway compared with Iceland (data are not available from Sweden).

For most of the psychosocial working environment factors in Appendix 1, comparison between the countries is not directly possible, either because data are missing, or because different questions and scales are used in the surveys. However, some striking differences may still be noted.

In Sweden, older blue collar workers experience fewer conflicts at work than all older workers on average. However, the opposite is the case in Denmark, where blue collar workers experience far more conflicts than all workers on average. Norwegian older workers report more time pressure than older workers in Denmark. Bullying/harassments are experienced by a far larger fraction of older workers in Denmark, than in Sweden (intermediary) and Norway (very low). Interestingly, older blue collar women in Denmark and Sweden experience more bullying than older blue collar men, whereas the opposite is the case in Norway. A far larger fraction of Swedish older workers is subject to violence or threats than older workers in Denmark and Norway. Norwegian and Icelandic older workers experience far more support and help from nearest leader than older workers in Sweden and Denmark. On the other hand, Swedish and Danish older workers experience more often to have control on how work is done than Norwegian older workers.

In conclusion, the comparison between Denmark, Norway and Sweden indicates that the physical and psychosocial working environment of Norwegian older workers and in particular the blue collar workers - is far better than that of older workers in Sweden and Denmark, except for monotonous work and job control. Since all working environment factors in Appendix 1 are known or suspected risk factors for early retirement, it is tempting to speculate that the better working environment, which is experienced by older Norwegian workers, contributes positively to the work retention of Norwegian older workers. 



\section{Discussion}

\subsection{The complex retirement decision process}

It is important to realize that the working environment is rarely the sole cause of early retirement, and in most cases, the working environment interacts with a multitude of other factors at the micro (individual health, economy etc.), meso (workplace, family and close social network) and macro (social security system and labour market legislation and regulation) level in the decision process to retire or continue working. As clearly illustrated in the theoretical framework the swAge model (http://www.swage.org/) proposed by Nilsson (2016) (figure 1) and in the conceptual model of Wang \& Shultz (2010) (figure 2), the retirement decision process is highly complex. We suggest that the decision process is essentially related to answering four general questions:

\subsubsection{Must I work?}

This question mainly relates to whether or not the person has economic possibilities for retirement. Many low-educated older workers are stuck at the labour market and in their job because they cannot afford to retire (either because they are not entitled to a pension, or because the pension is insufficient to cover their costs of living). This is particularly a problem for low-educated workers with limited savings. Obviously, raising the pension age limit will increased the fraction of older workers being stuck at the labour market.

\subsubsection{Can I work?}

This question relates to an imbalance between work demands (including straining work exposures) and the persons' capability to meet these demands. Reduced work capability due to health problems is a strong predictor for early retirement, particularly among loweducated older workers with high work demands. Reduced work capacity may also be the result of lack of new skills and competences. Particularly for older workers who are stuck at the labour market imbalance between work demands and work capacity may pose a risk of long-term negative health and social effects. However, so far no Nordic studies have been made on this group of older workers. In theory, work may be sustained if the work demands are reduced through work modification (technical aids to gain ergonomically improvements or shift to less demanding work tasks) or through reduction of work time (transition to part-time employment). Similarly, physical work capabilities and health can be improved through workplace health promotion and cognitive work capabilities can be improved by systematic competence improvement. However, only limited knowledge exists on effects of such interventions. 


\subsubsection{Will I work?}

This question relates to motivation to stay at work, which is closely linked to good social relations with colleagues and nearest leader, feeling a professional pride (work being an important part of the identity), recognition, engagement/commitment, feeling of meaningfulness in the work, influence at work, and opportunities for development at work. Low-educated workers (e.g. workers in care and industry) seem to be most motivated by being at work (the social aspect), whereas high-educated workers (e.g. engineers) often enjoy the work itself, the professional content of their work tasks and other aspects of their work (personal development).

\subsubsection{Can I get a job?}

Eurobarometer 2015 revealed that $56 \%$ of adult Europeans considered that a job applicant's age, if over 55 , would be a major disadvantage when seeking a new job. Being over age 55 was actually considered the most disadvantageous factor when applying for a new job, exceeding possible negative attitudes to the applicant's physical appearance, ethnicity, or having a visible disability. Consequently, lack of possibilities for obtaining a new job may - after a period of unemployment - be a strong driver for early retirement, even though the person would like to continue working. In all Nordic countries - but Iceland - employers are reluctant to recruit and call in for job interview older applicants, and the risk of long-term unemployment among older workers is higher in Denmark probably because job security is far lower than in the other Nordic countries.

Answering the four questions reveal that two major perspectives exist on labour market retention of older workers:

The protective perspective has focus on the large group of older workers, with limited resources due to attrition, health problems and lack of competences, who have particular needs for protection if they are to extend their work life in a sustainable manner.

The resource perspective has focus on the group of older workers, who have excellent health and many competences. The workplaces consider these workers to be a strong and productive resource, particularly if their high experience can be utilized. In order to extend the work life of this group of workers the workplace needs to focus on improving the job satisfaction.

\subsection{Major differences between the Nordic countries in exit culture, labour market regulations and policies}

Across the four Nordic countries - Denmark, Iceland, Norway and Sweden - significant differences in retirement age exist, and these differences may to some extent be attributable to historical, as well as current differences in exit culture, labour market regulations and policies. The major differences are summarized in Table 5 .

The effective retirement age in Denmark is profoundly lower than in the three other Nordic countries. One important reason is probably that voluntary early retirement can 
be taken in Denmark already at 60 years. Another reason is that older workers' exit to early voluntary retirement has been actively used in Denmark in times of high unemployment rates - both at the national and workplace level. As a consequence, early retirement is widely expected and socially accepted in Denmark, even though the retirement age has increased the last years. This is reinforced by the low job security in Denmark, compared with the other Nordic countries. In Denmark, all workers can easily be dismissed, and when this happens for an older worker, it may be difficult to obtain a new job at another workplace. In this situation, early retirement is considered a legitimate and worthy way out and, in Denmark long-term unemployment among older workers is a strong predictor for early voluntary retirement.

Table 5: Exit cultures, labour market regulations and policies in the Nordic countries (2017)

\begin{tabular}{|c|c|c|c|c|c|c|c|c|c|}
\hline & \multicolumn{2}{|c|}{$\begin{array}{l}\text { Effective age } \\
\text { of retirement } \\
(2009-2014)\end{array}$} & $\begin{array}{l}\text { Age for } \\
\text { taking } \\
\text { early } \\
\text { retirement } \\
\text { (2015) }\end{array}$ & $\begin{array}{l}\text { Age for } \\
\text { taking } \\
\text { state } \\
\text { pension } \\
(2015)\end{array}$ & $\begin{array}{l}\text { Exit } \\
\text { culture }\end{array}$ & $\begin{array}{l}\text { Exit via } \\
\text { disability } \\
\text { pension }\end{array}$ & $\begin{array}{l}\text { Part-time } \\
\text { employment } \\
\text { combined with } \\
\text { pension }\end{array}$ & $\begin{array}{l}\text { Unemploy- } \\
\text { ment rate }\end{array}$ & $\begin{array}{l}\text { Job security } \\
\text { by law }\end{array}$ \\
\hline & Men & Women & & & & & & & \\
\hline Denmark & 63.0 & 60.6 & 60.0 & 65.0 & Early & Rare & Rare & $\begin{array}{l}\text { Low } \\
\text { (Highest } \\
\text { for } 55^{+} \text {) }\end{array}$ & Low \\
\hline Iceland & 69.4 & 68.0 & 60.0 & 67.0 & Late & Rare & Rare & Low & Low \\
\hline Norway & 65.2 & 64.3 & $\begin{array}{l}62.0 \\
\text { Earning } \\
\text { test }\end{array}$ & $\begin{array}{l}62-75 \\
\text { Flexible }\end{array}$ & Late & Frequent & $\begin{array}{l}\text { Rare in private } \\
\text { sector. Frequent } \\
\text { in public sector. } \\
\text { Few restrictions }\end{array}$ & Low & $\begin{array}{l}\text { High } \\
\text { ( } 72 \text { years, } \\
\text { with the } \\
\text { possibility of } \\
70 \text { years) }\end{array}$ \\
\hline Sweden & 65.2 & 64.2 & 61.0 & 65.0 & Late & Frequent & Rare & Low & $\begin{array}{l}\text { High } \\
\text { (67 years) }\end{array}$ \\
\hline
\end{tabular}

Note: In the Table the quantitative measures "Rare" and "Frequent" are used somewhat arbitrarily. "Rare" signals that this is only a small fraction of the subpopulation in question, whereas "Frequent" means a large fraction of the subpopulation, but not necessarily the majority.

\subsection{The impact of the working environment on retirement}

As emphasized earlier, exit from labour market is caused by a complex interaction of a multitude of factors at the micro-, meso- and macro level, and it may be difficult to estimate the relative importance of the working environment. Still, attempts to estimate this have been made in Denmark and Norway.

In Denmark, a large fraction of disability retirement is attributable to high physical work demands (21\% for men and 34\% for women), and each of two psychosocial work factors (decision authority and variation) could explain $10-15 \%$ of the risk of disability retirement. Similar results were obtained in Norway, where five psychosocial and eight mechanical (ergonomic) risk factors at work could explain $45 \%$ of disability retirement; largest for standing (21\%) and monotonous work (19\%) for more than $3 / 4$ of the workday. 
In addition, several Norwegian studies have demonstrated that working environment risk factors could explain a large part of the social class inequality in disability retirement, demonstrating that poor working conditions are of particular concern when considering the retirement behaviours of low-educated workers.

Finally, approximately $30 \%$ of long-term sickness absence is attributable to the psychosocial working environment in Denmark, and between $31-54 \%$ of long-term sickness absence is attributed to the working environment in Norway.

In conclusion, it is well documented that the impact of the working environment on retirement behaviour is considerable.

\subsection{Work environment predictors of retirement}

In all Nordic countries, there is a strong social class gradient in exit to retirement, and ill health is a strong predictor for exit to both disability pension and voluntary early retirement. Social class and ill health are closely linked. III Health - particularly musculoskeletal health problems - often reduce work ability, and inability to cope with high job demands may push older workers out of work, particularly in strenuous, low skilled jobs. The combination of ill health and high physical work demands may to some extent explain why women retire earlier than men. Many women work in the public sector, and they have physically strenuous jobs and limited possibilities to move to other, less strenuous jobs.

The association between the working environment and labour market exit has been studied in detail in all Nordic countries for several work environment factors, and the results have generally been very similar. Therefore, we suggest that evidence from one country may be considered valid in the other Nordic countries as well. In Table 6 we have listed different work environment factors, as well as the number of Nordic studies covering each factor, and we have commented on the strength of the documentation of an association with early labour market exit.

We conclude the following work environment predictors of early labour market exit are well-documented: Occupational accidents, whole-body vibration, physical work demands (e.g. strenuous work, heavy lifting, prolonged standing), job control/autonomy/influence at work, job satisfaction, quantitative work demands (e.g. work speed and time pressure), leadership support, conflicts at work and bullying/harassment, and age discrimination. In addition, less strong but still reasonable documentation exists for possibility for competence development. Finally, limited Nordic research has been made on the impact of chemical work factors, noise, shift work, colleague/fellowship support, organisational commitment, and fear of reorganization on early labour market exit. 
Table 6: Work environment factors and association with retirement

\begin{tabular}{|c|c|c|}
\hline Work factor & $\begin{array}{l}\text { Number of } \\
\text { Nordic studies }\end{array}$ & Strength of documentation ${ }^{1}$ \\
\hline \multicolumn{3}{|l|}{ Occupational accidents } \\
\hline Occupational accidents & $\begin{array}{l}4 \mathrm{DK}, 2 \mathrm{l}, 3 \mathrm{NO}, \\
7 \mathrm{SE}\end{array}$ & $\begin{array}{l}\text { The association between occupational accidents and disability } \\
\text { retirement is well-documented. }\end{array}$ \\
\hline \multicolumn{3}{|l|}{ Chemical work factors } \\
\hline Air pollutants, Exhaust fumes & $2 \mathrm{NO}$ & $\begin{array}{l}\text { We consider one study to be of high quality, showing strong } \\
\text { association between disability pension and exhaust fumes. Due to the } \\
\text { low number of studies we consider the association to be uncertain. }\end{array}$ \\
\hline Cleaning agents and disinfectants & $1 \mathrm{DK}, 1 \mathrm{NO}$ & $\begin{array}{l}\text { One study in DK shows an association between exposure and } \\
\text { disability retirement, but the association may reflect socioeconomic } \\
\text { gradient. A study in NO find associations between sick leave and } \\
\text { occupational skin exposure to cleaning products and waste among } \\
\text { men, and water among women. Due to the low number of studies } \\
\text { we consider the association to be uncertain. }\end{array}$ \\
\hline
\end{tabular}

Physical work factors

Whole-body vibration

Noise

Strenuous work - high physical work demands

Strenuous work - high physical work demands
$1 \mathrm{DK}, 2 \mathrm{NO}$

$1 \mathrm{DK}, 1 \mathrm{NO}$

A multitude of Nordic studies
All studies are of good quality and show a strong association with exit to disability pension. We consider the association to be welldocumented.

Uncertain. Only two inconclusive studies.
In general, the studies show a strong association between high physical work demands and retirement (both disability retirement and voluntary early retirement), and the association is welldocumented. The most frequently reported work factors are:

Strenuous work - Heavy/awkward lifting - Repetitive work Work with hands lifted - Prolonged standing.

Job control/autonomy/influence at work

Job satisfaction

Shift work

Psychological work demands (work speed, time pressure, emotional demands)
A multitude of Nordic studies

$3 \mathrm{DK}, 5 \mathrm{NO}, 2 \mathrm{SE}$

$2 \mathrm{DK}, 1 \mathrm{NO}$

$1 \mathrm{DK}, 1 \mathrm{NO}$

For some psychosocial work factors, the studies show conflicting results.

Low job control/autonomy is strongly associated with disability retirement and voluntary early retirement in several studies in NO. Low control is a risk factor for early retirement in $\mathrm{SE}$, and low influence at work is a risk factor for early voluntary retirement in DK. We consider the association to be well-documented.

Low job satisfaction is associated with disability retirement and voluntary early retirement in DK and NO. The studies are of high quality and we consider the association to be well-documented.

Shift work is associated with disability retirement among women, but not men in DK. In NO shift work does not contribute to gender difference in disability retirement. Due to the low number of studies we consider the association to be uncertain.

$6 \mathrm{DK}, 2 \mathrm{NO}, 1 \mathrm{SE}$ Psychological work demands are risk factor for disability retirement in $\mathrm{SE}$, but one study does not find this in NO, and in NO psychological work demands are only risk factors for early voluntary retirement. Most studies in DK find time pressure to be a risk factor for early voluntary retirement, but one study does not find a significant association. We consider the association to be welldocumented. 
Psychosocial work factors Leadership support/quality

Poor colleague fellowship/support

$2 \mathrm{DK}, 1 \mathrm{NO}, 1 \mathrm{SE}$

development

Organisational commitment

2 DK

$1 \mathrm{NO}$

Fear of reorganisation

Conflicts at work/

bullying/harassment

Age discrimination

Age discrimination

$5 \mathrm{DK}, 2 \mathrm{NO}, 1 \mathrm{SE}$ Low leadership support is associated with disability retirement and early voluntary retirement in NO. In DK three studies find leadership support/quality to be a predictor of voluntary early retirement, whereas two studies do not find this. Leadership support is associated with intention to retire early in SE. We consider the association to be well-documented.

Poor colleague fellowship/support is a risk factor for disability retirement in $\mathrm{NO}$ and intention to retire early in SE. In DK one study does not find an association between poor colleague support and voluntary early retirement, and another study find good social relations to colleague to be associated with late retirement. Due to the low number of studies, and conflicting results we consider the association to be uncertain.

One Danish study finds a causal link between low possibility for competence development and disability pension retirement, And one Norwegian study finds that high possibility for competence development predicts low transition to disability pension. Three studies in DK find that low possibility for competence development is associated with voluntary early retirement, and We consider the association to be moderately documented.

Low organisational commitment is a risk factor for intention to retire early in DK. Due to the low number of studies we consider the association to be uncertain.

Fear of reorganisation is a risk factor for disability retirement in NO. Due to the low number of studies we consider the association to be uncertain.

4 DK, 1 NO, 6 SE Conflicts at work, bullying and harassment have been shown to be risk factors for early voluntary retirement in DK and S. A study in NO found bullying/harassment to be a non-significant risk factor for disability retirement. We consider the association to be well-documented.

Several Nordic reports
In DK, NO and SE several reports document the existence of age discrimination. Age discrimination appears to be more frequent in DK than in the other Nordic countries, probably reflecting the early exit culture in Denmark. It seems well-documented that the most prominent effect of age discrimination is that older workers have very limited possibilities to get a new job if they become unemployed, and therefore often are forced to take early retirement.

Note: The authors of this report have considered the level of documentation using a few simple and pragmatic criteria: If several studies have been performed in several Nordic countries, and the majority (all) of the studies point in the same direction, we consider it to be well-documented. If only one or two studies have been made we consider the documentation to be uncertain. In case of the psychosocial risk factors "possibility for competence development" three studies have been made, all in Denmark. Here we considered the documentation to be moderate. 


\subsection{Comparison of the working environment of older workers in the Nordic countries}

We argue that the working environment of different jobs may to some extent be similar in all Nordic countries, i.e. construction work is physically strenuous, and office work is sedative in all countries. National surveys on working environment and health are carried out in Denmark, Iceland, Norway and Sweden. We have extracted data on the working environment of older workers from the national surveys (see appendix 1 ).

Comparison of data from the four countries reveals similarities, but also distinct differences.

Danish older blue collar women report far more exposure than men to work with monotonous movements, whereas blue collar women and men in Norway and Sweden report approximately the same exposure to monotonous movements. Moreover, In Norway and Sweden older blue collar women tend to report less exposure to physical strenuous work (particularly low in Sweden), less exposure to heavy lifting (particularly low in Norway), and less exposure to work with hands lifted above shoulder than older blue collar men, whereas the opposite is the case for Denmark. In general, the physical working environment of Danish blue collar women appears to be more demanding than that of Norwegian and Swedish older blue collar women.

Danish and Swedish older workers report approximately the same, high exposure to work in awkward position, and to work with hands lifted above shoulder. For both physical working environment factors the exposures far exceed the exposures of Norwegian older workers, and Danish and Swedish older men are more exposed to vibrations and loud noise than Norwegian older men.

Danish and Swedish older workers report far more occupational accidents than older workers in Norway and Iceland.

Bullying/harassments are experienced by a far larger fraction of older workers in Denmark, than in Sweden (intermediary) and Norway (very low). Norwegian older workers experienced far more support and help from nearest leader than older workers in Sweden and Denmark. On the other hand, Swedish and Danish older workers experience more often to have control on how work is done than Norwegian older workers.

Altogether, the physical and psychosocial working environment of Norwegian older workers - and in particular the blue collar workers - appears to be much better than that of older workers in Sweden and Denmark. It is tempting to speculate that the better working environment, which is experienced by older Norwegian workers, contributes positively to the work retention of older workers in Norway.

\subsection{Effects of workplace interventions to increase retention of older workers}


In all Nordic countries, many workplaces claim to have a policy for retention of older workers, but in Denmark and Norway less than half of the workplaces have practical activities to promote retention of older workers. Most frequently, the workplace policies and activities aim to provide possibility for stepping down and get a gradual exit of the labour market. The activities are mainly comprised of flexible work-time, worktime reduction, more days on leave/holiday, and bonuses. More rarely, the activities are reduced workload, improved ergonomics, or competence development. Effects of companies' work-place policies and activities to increase retention of older workers have only been systematic evaluated in Norway. In general, these studies finds that intervention offered by Norwegian companies have limited effect on early retirement and sickness absence. However, they find that companies interventions targeted at workers with health problems and reduced work capacity reduce the probability of disability pensioning. Two study also found that older workers who are offered either extra days off or a retention bonus, respectively, have a reduced probability of voluntary early retirement at age 62 and 63 . Another study shows that reduction of work hours with some wage compensation has no effect on retirement behaviour.

Failure to demonstrate general effects of intervention actually offered by companies does not rule out that positive effects may occur for other types of intervention, or may occur for some group of workers, in some companies and industries. In all Nordic countries, several case stories exist, in which workplaces state to have retained older workers successfully due to specific interventions. Eurofound has collected more than 200 case examples on workplace age management, 13 cases are from Denmark, and 7 cases are from Sweden (www.eurofound.europa.eu/observatories/eurwork/casestudies/ageing-workforce). Some case stories on SMEs, which show informal practices to effectively retain older workers, may be of particular interest, since SMEs typically do not have large resources and knowledge to inform and support their practical efforts to retain older workers.

Even though a good working environment is of paramount importance for retention of older workers, the existing knowledge is sparse regarding the effects on retirement behaviors of interventions to improve the working environment. One promising Norwegian study shows that workplace interventions to prevent physical exhaustion reduce the risk of disability pensioning even though the risk of sickness absence is not reduced. The current knowledge seems to indicate a great potential in developing workplace interventions which combine prevention of working environment risk factors (e.g. risk factors for accidents, strenuous work/high physical work demands, quantitative work demands, conflicts at work and bullying/harassment, and age discrimination) with increment of job satisfaction through increased control/influence, possibilities for development and recognition from management.

\subsection{Research needs}

The ageing workforce is high on the political agenda in all European countries, and the European Commission has issued a project "Safer and Healthier Work at Any Age" to be 
carried by the European agency for Safety and Health at Work (EU-OSHA) (Andersen et al., 2016; Belin et al., 2016). As part of this project several reviews have been prepared by working groups also including prominent researchers from the Nordic countries. Even though the reviews of the "Safer and Healthier Work at Any Age" project provides a series of recommendations both to national legislations and regulations and at the workplace level, there are still large and important knowledge gaps.

The research needs are linked to the following themes:

- Achievement of a sustainable work-life balance for all. There is a need for more research on effective workplace policies and interventions to increase sustainable retention of older workers. In particular, knowledge is needed for older loweducated women workers who are stuck in jobs with physical high demands (e.g. health care, service and cleaning). In addition, immigrant workers often are loweducated with manual work with high physical demands. Hence, immigrant workers may be a particular high risk group, but the current knowledge on how to prevent early labour market exit among older immigrant workers is sparse.

Finally, the fraction of older workers with debilitating chronic diseases is expected to increase in future, thus, research is needed on work adaptation to accommodate these older workers. There is a need for new workplace interventions which combine prevention of working environment risk factors and age discrimination with increment of job satisfaction of the employees. In addition, there is urgent need for more "from research to practice" knowledge on how to disseminate knowledge on efficient interventions to the workplaces.

- Long-term consequences of an extended work-life. Particularly for low-educated older workers with straining work exposures, more knowledge is needed on potential negative consequences of longer and cumulative exposure to occupational hazards on health and well-being during work and after retirement. Hence, evaluation of workplace policies and interventions should not only focus on work retention (i.e. expected and actual retirement age) but also on workers' health and well-being during the extended work life and after retirement. In this context, knowledge is also needed to clarify if and how OSH regulation can take into account new problems related to longer and cumulative exposure to occupational hazards, also in combination with increased prevalence of chronic health problems. Here an important shortcoming relates to lack of knowledge on effects of the opportunities for transfer between different social benefit schemes (unemployment, sickness absence, social security aids, and disability schemes). In theory, labour market regulations - restricting the access to retirement - may not necessarily increase the fraction of older people being actively employed at the labour market. Alternatively, increased transfer to different social benefit schemes may occur, particularly for older people with low labour market mobility due to lack of education and/or chronic health conditions.

- The dynamics of the retirement process. So far, most studies have considered retirement a single, finished event, not considering that the decision to retire and 
the retirement process itself may extend several years. A longer (life course) perspective is needed on work ability and work attitudes, how these factors change over time, and how older workers gradually adapt to the future life as pensioners. In this context, more knowledge is also needed on, how health, wellbeing and quality of life change during the retirement process. Here more knowledge is also needed on possible positive effects of voluntary part-time employment in combination with partial retirement.

- The workplace perspective. Less than half of the workplaces (in Denmark and Norway) have practical activities to promote retention of older workers, and even though several studies have been made in Norway more knowledge is needed on the motives and perspectives of the workplaces: Why do some workplaces - but not all - decide to carry out activities to recruit and/or retain older workers? Which types of older workers are offered the senior retention interventions and why? Knowledge is lacking on the actual needs of SMEs in particular, and how these needs can be met. Potentially important case stories exist on workplaces (e.g. whole sale and building markets) who have actively recruited senior employees to utilize their experience, but the cases have not been systematically described, and the current knowledge on effects of this type of senior policy is sparse. Finally, Even though a good deal of research based knowledge exists, the use of the knowledge at the workplaces is very limited. It may well be that most workplaces do not have large resources to gather knowledge to inform and support their workplace policies and practical activities, and lack of knowledge may be an important barrier to obtaining a sustainable extended work life particularly at SMEs. Therefore, there is also a strong need for more efficient knowledge dissemination from research to practice at workplaces. In Norway SSP (Senter for Seniorpolitikk) is active in this field and may serve as an example.

- Combating age discrimination. In all Nordic countries, age discrimination occurs. The most prominent effect of age discrimination is that older workers have very limited possibilities to get a new job if they become unemployed, and therefore often are either stuck in a job in which the demands exceed their work capacity or are forced to take early retirement. Effective ways to combat age discrimination need to be developed. In this context, more knowledge is needed on how cultural perceptions at the society level and negative attitudes and behaviours at the workplaces can be altered. However, it should also be acknowledged that the workplaces may have objective reasons for being reluctant to hire older workers, e.g. due to seniority-based salary systems, older workers may expect higher wages than they are considered to be worth, and investment in development of the specific competence needed for the job may be considered less cost-efficient. Hence, there is also a need to look more closely at the workplace perspective, and to answer the questions: What are the objective reasons for workplaces being reluctant to hire older workers? And how can the needs of the workplaces be met?

- Combating stigmatization. If labor market policies and workplace senior policies and activities focus on older workers as potentially "vulnerable", and if older 
workers are selectively entitled to a better working environment and better work condition than their younger counterparts, there are risks of stigmatization.

Stigmatization may have severe negative consequences, i.e. tension between age groups resulting in reduced social support and coherence, reduced workplace commitment, reduced job satisfaction etc. However, the social partners and the working environment authorities (OSH regulation) in the Nordic countries, so far have had a life-course approach to $\mathrm{OSH}$, focusing on all workers. Hence, there has been little tradition for a particular focus on older workers. High awareness on the risk of stigmatization may be needed when implementing labor market and workplace senior policies, but so far little is known on why and when stigmatization occurs, and what the consequences are. 



\section{References}

AFA-försäkring (2015). Allvarliga arbetsskador och långvarig sjukfrånvaro - 2015. Stockholm.

Ahlberg G., S. Marklund, C. Stenlund, M. Torgén (2001). Anställdas arbetssituation, hälsa och attityder till pensionering. Handlingsplan för ökad hälsa i arbetslivet Vol 2, p. 33-99. In SOU 2002 Vol. 5.

Ajslev J.Z.N. (2015). Smerte som kollektiv vane - Om bygningsarbejdere og smerte i en agentiel realistisk ramme for en biopsykosocial model. Ph.d. afhandling, Roskilde Universitet.

Alfonso J.H., T. Tynes, J.P. Thyssen, L.Ø. Holm, \& H.A. Johannessen (2016). Self-reported Occupational Skin Exposure and Risk of Physician-certified Long-term Sick Leave: A Prospective Study of the General Working Population of Norway. Acta Derm Venereol. Vol. 96 No. 3, p. 336-40. https://doi.org/10.2340/00015555-2253

Andersen J.G. Chap 4 in P.H. Jensen PH, T. Rostgaard (eds) (2015). Det Aldrende SamfundUdfordringer og nye muligheder. Bogforlaget Frydenlund. ISBN 978-87-7118-328-3.

Andersen J.G., P.H. Jensen (2011). Tilbagetrækning fra arbejdsmarkedet - årsager og effekter. Bogforlaget Frydenlund. ISBN 978-87-7118-016-9.

Andersen R.V., M.V. Petersen, E. Fries-Tersch (2016). European agency for Safety and Health at Work (EU-OSHA). Safer and Healthier Work at any age - Country inventory: Denmark.

Andersson L. (2008). Ålderism. Lund, Studentlitteratur.

Andreassen L., T. Kornstad (2010). Transitions to disability and rehabilitation. Discussion paper no. 641. Oslo, Statistics Norway, Research Department.

Arbejderbevægelsens Erhvervsråd (Juni 2016a). Tema: Arbejdsmiljø. Stress, mobning og tunge løft sender folk ud af arbejdsmarkedet.

Arbejderbevægelsens Erhvervsråd (Oktober 2016b). Tema: Portræt af generation 1950-54. Ufaglærte og faglærte betaler for senere tilbagetrækning.

Arbetsmiljöverket (2012). The work environment 2011. Vol 2012 No. 4.

Barslund M. (2015). Extending working lives: The case of Denmark. CEPS working Document No. 404, February 2015. ISBN 978-94-6138-450-8.

Becken L.E. (2011). Redusert arbeidstid med full lønnskompensasjon blant seniorer med rett til AFP i fire statlige etater. Søkelys på arbeidslivet Vol. 28 No. 4, p. 374-393.

Becken L.E. (2012). Seniortiltak og pensjonerings-adferd for seniorer med rett til AFP i statlig sector. Søkelys på arbeidslivet Vol. 29 No. 4, p. 349-367.

Belin A., C. Dupont, L. Oulés, Y. Kuipers (2016). European agency for Safety and Health at Work (EU-OSHA). Safer and Healthier Work at any age - Final overall analysis report.

Executive summary.

Bengtsson E., K. Nilsson (2004). Äldre medarbetare. [Older worker.] Malmö, Swedish National Institute of Working life (in Swedish). http://nile.lub.lu.se/arbarch/ovrigt/2004/ovr2004_12.pdf

Blekesaune M., P.E. Solem PE (2005). Working conditions and early retirement a prospective study of retirement behavior. Research on Aging Vol. 27 No. 1, p. 3-30.

https://doi.org/10.1177/0164027504271438

Beehr T.A., M.M. Bennett (2015). Working After Retirement: Features of Bridge Employment and Research Directions- Work. Aging and Retirement Vol. 1 No. 1, p. 112-128.

https://doi.org/10.1093/workar/wauoo7

Bogen H., A.I. Hilsen (2013). Seniorpolitikk under skiftende forhold. Gjenbesøk i seks kommuner. Fafo-rapport 2013:07. Oslo, Fafo Institute for Labour and Social Research.

Bogen $\mathrm{H}$., T. Midtsundstad (2007). Noen år til. Erfaringer med seniorpolitikk i seks kommuner, Fafo-rapport 2007 Vol. 28. Oslo, Fafo. 
Borg V. (2005). Sund i arbejde - positive faktorer i arbejdet. Nordisk Ministerråd.

Borg V. (2016). Attraktive Arbejdspladser for Aktive Seniorer. Slutrapport til

Arbejdsmiljøforskningsfonden.

Brage S., I. Sandanger, J.F. Nygård (2007). Emotional distress as a predictor for low back disability: a prospective 12-year population-based study. Spine Vol. 32 No. 2, p. 269-274. https://doi.org/10.1097/01.brs.0000251883.20205.26

Bratsberg B., E. Fevang, K. Røed (2010). Disability in the welfare state: An unemployment problem in disguise? Discussion paper series // Forschungsinstitut zur Zukunft der Arbeit, No. 4897. Der Open-Access-Publikationsserver der ZBW - Leibniz-Informationszentrum Wirtschaft www.econstor.eu, Institute for the Study of Labor (IZA).

Brinch C.N., E. Hernæs, Z. Jia (2012). Labor supply on the eve of retirement. Disparate effects of immediate and postponed rewards to working. Discussion papers no. 698. Oslo, Statistics Norway. Research department.

Bruusgard D., A. Hatland, A. Syse (1994). Et nødvendig gode: Folketrygdens plass $i$ VelferdsNorge. Pg 225-242 in Halvorsen K (Editor). Velger folk trygd for vinnings skyld?. Oslo: Ad Notam Gyldendal.

Bruusgaard D., L. Smeby, B. Claussen (2010). Education and disability pension: a stronger association than previously found. Scand. J. Pub. Health Vol. 38 No. 7, p. 686-69o. https://doi.org/10.1177/1403494810378916

Bråthen M. (2011). Uførepensjonisters tilknytning til arbeidslivet. NAV-rapport. Oslo, Arbeids- og velferdsdirektoratet, Stab for analyse og strategi / Seksjon for utredning.

Bråthen M., F. Bakken (2013). Arbeid eller pensjon? En studie av hvilke faktorer som påvirker seniorenes beslutning om å fortsette i jobb? NAV-rapport 2013 Vol. 1. Oslo, Arbeids- og velferdsdirektoratet (NAV).

Bråthen M, Grambo AC (2009). Sysselsettingseffekten av endrede regler for alderspensjon for 67-åringer. Arbeid \& Velferd, 2009(2).

Christensen K.B., M.L. Nielsen, R. Rugulies, L. Smith-Hansen, T.S. Kristensen (2005). Workplace levels of psychosocial factors as prospective predictors of registered sickness absence. $J$ Occ Environ Med Vol 47, p. 933-940. https://doi.org/10.1097/01.jom.0000172864.16001.85

Christensen K.B., H. Feveile, M. Labriola, T. Lund (2008). The impact of psychosocial work environment factors on the risk of disability pension in Denmark. Eur J Public Health Vol. 18 No. 3, p. 235-237. https://doi.org/10.1093/eurpub/ckm130

Claus G., P. Nordby, H. Næsheim (2014). Yrkesaktivitet blant eldre før og etter pensjonsreformen. Rapport 2014 Vol. 19. Oslo, Statistic Norway.

Clausen T., P. Tufte, V. Borg V (2014a). Why are they leaving? Causes of actual turnover in the Danish eldercare services. Journal of Nursing Management Vol. 22 No. 5, p. 583-592. Epub ahead of print 2012: DOI: 10.1111/j.1365-2834.2012.01484

Clausen T, H. Burr, V. Borg (2014b). Do psychosocial work conditions predict risk of disability pensioning? An analysis of register-based outcomes using pooled data on 40,554 observations. Scand J Public Health Vol 42 No. 4, p. 277-384. https://doi.org/10.1177/1403494814527187

Clausen T, H. Burr, V. Borg (2014C). Do psychosocial job demands and job resources predict long-term sickness absence? An analysis of register-based outcomes using pooled data on 39,408 individuals in four occupational groups. Int Arch Occup Environ Health Vol. 87 No.8, p. 909-917. DOI: 10.1007/s00420-041-0936-7

Claussen B., O.S. Dalgard (2009). Disability pensioning: the gender divide can be explained by occupation, income, mental distress and health. Scand J Pub Health Vol 37 No. 6, p. 590-597. https://doi.org/10.1177/1403494809105795

Dahl E.H., O.C. Lien (2013). Pensjonsreformen - flere eldre i arbeid. Arbeid \& Velferd 2013 Vol. 1, p. $58-70$. 
Dalen E. (2013). Norsk Seniorpolitisk Barometer 2013. Kommentarrapport LEDERE I

ARBEIDSLIVET. Oslo, Ipsos MMI AS.

Econ P. (2009). Redusert arbeidstid for seniorer med rett til AFP. Utarbeidet for Senter for seniorpolitikk. ECON-rapport nr. 2009-084. Oslo, Econ Pöyry.

Econ P. (2010). Evaluering av forsøk med redusert arbeidstid for seniorer. Sluttrapport. Econrapport nr. 2010-044. Oslo, Econ Pöyry.

Emberland J.S., M.B. Nielsen, S. Knardahl (2017). Psychological, social, and mechanical work exposures and disability retirement: a prospective registry study. BMC Public Health Vol 17. No. 56, p. 1-11. https://doi.org/10.1186/s12889-016-3921-o

Eurofound (2016). Extending working lives through flexible retirement schemes: Partial retirement. Authors Hans Dubois, Georgiana Runceanu and Robert Anderson. Doi: $10.2806 / 004233$

Eurobarometer (2012). Active ageing.

http://ec.europa.eu/public_opinion/archives/ebs/ebs_378_en.pdf

Eurobarometer (2015). Eurobarometer on Discrimination 2015: General perceptions, opinions on policy measures and awareness of rights. http://ec.europa.eu/justice/fundamentalrights/files/factsheet_eurobarometer_fundamental_rights_2015.pdf

Fevang E., S. Kverndokk, K. Røed (2009). Omsorg for foreldre - hvordan påvirkes yrkesdeltakelsen? Søkelys på arbeidslivet Vol. 26 No. 1, p.113-123.

Feveile H., K.B. Christensen, M.-A. Flyvholm (2009). Self-reported occupational skin contact with cleaning agents and the risk of disability pension. Contact Dermatitis Vol. 6o No. 3: p. 131-135. https://doi.org/10.1111/j.1600-0536.2008.01495.X

Foss L., H.M. Gravseth, P. Kristensen, B. Claussen, I.S. Mehlum, K. Skyberg (2010). Risk factors for long-term absence due to psychiatric sickness: a register-based 5 -year follow-up from the Oslo health study. J Occup Environ Med Vol. 52 No. 7: p. 698-705. https://doi.org/10.1097/JOM.obo13e3181eg8731

Foss L., H.M. Gravseth, P. Kristensen, B. Claussen, I.S. Mehlum, S. Knardahl, K. Skyberg (2011). The impact of workplace risk factors on long-term musculoskeletal sickness absence: a registry-based 5-year follow-up from the Oslo health study. J Occup Environ Med Vol. 53 No. 12, p. 1478-1482. https://doi.org/10.1097/JOM.obo13e3182398dec

Friis K, Ekholm O, Andersen Hundrup Y (2005). Faktorer af betydning for sygeplejeskers tilbagetrækning fra arbejdsmarkedet. Statens Institut for Folkesundhed.

Furunes T., R.J. Mykletun RJ (2007). Why diversity management fails: Metaphor analyses unveil manager attitudes. International Journal of Hospitality Management Vol. 26 No. 4, p. 974-990. https://doi.org/10.1016/j.ijhm.2006.12.003

Furunes T., R.J. Mykletun, P.E. Solem PE (2011). Age management in the public sector in Norway: exploring managers' decision latitude. Int J Hum Resour Manag Vol. 22 No. 6, p. 1232-1247. https://doi.org/10.1080/09585192.2011.559096

Furåker B., K. Nergaard, A. Saloniemi (2014). Lock-in Patterns among Employees: A Nordic Comparison. The International Journal of Comparative labour Law and Industrial relations Vol. 30 No. 4, p. 453-458.

Gautun H., K. Hagen (2010). How do middle-aged employees combine work with caring for elderly parents? Community, Work \& Family Vol. 13 No. 4, p. 393-409.

https://doi.org/10.1080/13668800903360625

Gravseth H.M., T. Bjerkedal, L.M. Irgens, O.O. Aalen, R. Selmer, P. Kristensen (2007). Life course determinants for early disability pension: a follow-up of Norwegian men and women born 1967-1976. Eur J Epidemiol Vol. 22 No. 8, p. 533-43. https://doi.org/10.1007/s10654-0079139-9

Gravseth H.M., T. Bjerkedal, L.M. Irgens, O.O. Aalen, R. Selmer, P. Kristensen (2008). Influence of physical, mental and intellectual development on disability in young Norwegian men. Eur J Public Health Vol. 18 No. 6, p. 650-5. https://doi.org/10.1093/eurpub/ckno55 
Gupta N.D., M. Larsen (2010). The impact of health on individual retirement plans: Selfreported versus diagnostic measures. Health Economics Vol. 19, p. 792-813.

https://doi.org/10.1002/hec.1523

Hagen K.B., K. Tambs, T. Bjerkedal (2002). A prospective cohort study of risk factors for disability retirement because of back pain in the general working population. Spine Vol. $27 \mathrm{No}$. 16, p. 1790-1796. https://doi.org/10.1097/00007632-200208150-00019

Hagen K.B., K. Tambs, T. Bjerkedal (2006). What mediates the inverse association between education and occupational disability from back pain? - A prospective cohort study from the Nord-Trøndelag health study in Norway. Social Science and Medicine Vol. 63 No. 5, p. 1267-1275. https://doi.org/10.1016/j.socscimed.2006.03.041

Hagen J. (2016). Essays on Pensions, Retirement and Tax Evasion. Economic studies Vol. 158, 195 pages. Uppsala: Department of Economics, Uppsala University. ISBN 978-91-85519-65-1.

Halvorsen B., J. Tägtström (2013). A matter of health and job satisfaction Seniors, work and retirement in the Nordic region. Nordic Council of Ministers, Copenhagen.

https://doi.org/10.6027/TN2013-543

Hasselhorn H.M., W. Apt (2015). Understanding Employment Participation of Older Workers: Defining Research Needs for Evidence-based Policy. Federal Ministry of Labour and Social Affairs, Germany.

Haukenes I., A. Mykletun, A. Knudsen, H.-T. Hansen, J. Mæland (2011). Disability pension by occupational class - the impact of work-related factors: The Hordaland Health Study Cohort. BMC Public Health Vol. 11 No. 1, p. 406. https://doi.org/10.1186/1471-2458-11-406

Helgason T., K.Tómasson, E. Sigfússon, T. Zoëga (2004). Skimun Fyrir Algengi Geðraskana 1984 Og 2002 Og Ávisanir Geðlyfja 1984 Og 2001 (Screening for Mental Disorders in the Community 1984 and 2002 and Prescriptions for Psychopharmaca in 1984 and 2001). Journal Article. Læknabladið Vol. 90, p. 553-59.

Hem K.-G., Ø. Dahl, T. Rohde, A. Øren (2016). Kostnader ved arbeidsrelaterte sykdommer og skader. SINTEF-rapport A27430. Oslo: SINTEF. Teknologi og samfunn, Avdeling Helse.

Hermansen $\AA$. (2011). Pensjonering før fylte 67 år. Tidligpensjonering og bruk av AFP innen KS' tariffområde 2002-2009. Fafo-rapport 2011 Vol. 23. Oslo, Fafo.

Hermansen $\AA$. (2014). Additional leave as the determinant of retirement timing - retaining older workers in Norway. Nordic Journal of Working Life Studies Vol. 4 No. 4, p. 89-108.

https://doi.org/10.19154/njwls.v4i4.4709

Hermansen $\AA$. (2015). Retaining older workers - The effect of phased retirement on delaying early retirement. Nordic Journal of Social Research vol. 6.

Hermansen Å., T. Midtsundstad T (2015). The effect of retaining bonuses on early retirement retaining older Norwegian workers. Paper, presented at The 12th ESA e ConferenceDifferences, Inequalities and Social Imagination, Praha, 25.-28. August 2015.

Hernæs E., K. Røed, S. Strøm (2002). Yrkesdeltakelse, pensjoneringsadferd og økonomiske insentiver. Rapport 4/2002. Oslo: Stiftelsen Frischsenteret for samfunnsøkonomisk forskning (Ragnar Frisch Centre for Economic Research).

Hernæs E., Z. Jia (2009). Labour supply response of a retirement earnings test reform. Memorandum//Department of Economics, University of Oslo.

Hernæs E., S. Markussen, J. Piggott, K. Røed (2016). Pension reform and labor supply. Journal of Public Economics Vol. 142, p. 39-55. https://doi.org/10.1016/j.jpubeco.2016.08.009

Hilsen A.I. (2009). "Go for a senior": From work ability to senior resources, changing perceptions of seniors in working life. Tapir Uttrykk.

Hilsen A.I. (2012). Seniorpolitikk i store virksomheter - følgeevaluering ved St. Olavs Hospital. AFI-rapport 2012 Vol. 15. Oslo, Work research Institute.

Hilsen A.I., R. Salomon (2010). Seniorpolitikk - virker virkemidlene. AFI-rapport 2010 Vol. 4.

Hilsen A.I., V. Mathisen Olsvik, T Steinum (2009). På seniorvis. Seniorpolitikk i kvinnedominerte bransjer, tiltak for å hindre tidlig avgang i hotell og helsevesen. AFI-rapport 2009 Vol. 4. Oslo, Work Research institute (WRI). https://doi.org/10.7577/afi/rapport/2009:4 
Hippe J.M., T. Midtsundstad (2016). Teller AFP med? Omlegging av AFP og tilpasninger av tjenestepensjoner i privat sektor. Fafo-notat 2016 vol. o8. Oslo, Fafo.

Hogstedt C, E. Vingård E (2011). Vad vet vi om arbete, hälsa och ålder - en kunskapsöversikt. Stockholm.

Holte H.H., S. Krokstad, P Magnus (2000a). Årsaker til uførepensjonering [Causes of disability retirement.] Oslo: Norwegian Institute of Public Health, Report no 5.

https://www.fhi.no/globalassets/migrering/dokumenter/pdf/arsaker-til-uforepensjonering-pdf.pdf

Holte H.H., K. Tambs, T. Bjerkedal (200ob). Manual work as predictor for disability pensioning with osteoarthritis among the employed in Norway 1971-1990. Inter J Epidemiology Vol. 29 No. 3, p. 487-94.

Holte H.H., K. Tambs, T. Bjerkedal (2001). Becoming a disability pensioner with rheumatoid arthritis in Norway 1971-1990. Journal of Rheumatology Vol. 28 No. 1, p. 54-61.

Holte H.H., K. Tambs, T. Bjerkedal (2002). Physically demanding situations as predictors of disability pensioning with soft tissue rheumatism among persons 30-39 years old in Norway, 1981-9o. Journal of Rheumatology Vol. 29 No. 8, p. 1760-1766.

Hult C., M. Stattin (2009). Age, Policy Changes and work Orientation: Comparing Changes in commitment to Paid work in Four European Countries. J. Population Ageing Vol. 2 No. 3, p. 101-120. https://doi.org/10.1007/s12062-010-9023-3

Hult C., M. Stattin. U. Janlert, B. Järvholm (2010). Timing of retirement and mortality - A cohort study of Swedish construction workers. Social Science \& Medicine Vol.70, p. 1480-1486. https://doi.org/10.1016/j.socscimed.2009.10.043

Høgelund J., L. Brink Thomsen (2011). Efterløn og nedslidning. Socialforskningsinstituttet. Iceland Online Occupational Accident Register. http://vefkerfi/slysaskraning/t\%C3\%B6lfr\%C $3 \%$ A6\%C3\%Boi.aspx

Jacobsen V., S. Jensen, H. Holt, M. Larsen (2014). Virksomheders sociale engagement. SFI-Det Nationale Forskningscenter for Velfærd 2014 Vol. 14 No. 27.

Jensen P.H. Chap 2 in J.G. Andersen, P.H. Jensen PH (eds) (2011). Tilbagetrækning fra arbejdsmarkedet - årsager og effekter. Bogforlaget Frydenlund. ISBN 978-87-7118-016-9.

Jensen P.H. Chap 4 in J.G. Andersen, P.H. Jensen PH (eds) (2011). Tilbagetrækning fra arbejdsmarkedet - årsager og effekter. Bogforlaget Frydenlund. ISBN 978-87-7118-016-9.

Jensen P.H., P.T. Madsen Chap 3 in P.H. Jensen, T. Rostgaard (eds) (2015). Det Aldrende Samfund - Udfordringer og nye muligheder. Bogforlaget Frydenlund. ISBN 978-87-7118-328-3.

Jensen P.H., R. Juul Møberg Chap 5 in J.G. Andersen, P.H. Jensen (eds) (2011). Tilbagetrækning fra arbejdsmarkedet - årsager og effekter. Bogforlaget Frydenlund. ISBN 978-87-7118- 016-9.

Jensen P.H., R. Juul Møberg (2012). Age Management in Danish Companies: What, How and How Much? Nordic Journal of Working Life Studies Vol. 2 No. 3, p. 49-65.

https://doi.org/10.19154/njwls.v2i3.2363

Jia Z. (2005a). Labor supply of retiring couples and heterogeneity in household decision-making structure. Review of Economics of the Household Vol. 3 No. 2, p. 215-233. https://doi.org/10.1007/s11150-005-0711-3

Jia Z. (2005b). Retirement behavior of working couples in Norway. A dynamic programming approach. Discussion Papers No. 405, February 2004. Oslo, Statistics Norway, Research Department.

Jokela M., J.E. Ferrie, D. Gimeno, T. Chandola, M.J. Shipley, J. Head, J. Vahtera, H. Westerlund, M.G. Marmot, M. Kivimäki (2010). From Midlife to early Old Age. Health trajectories Associated With Retirement. Epidemiology Vol. 21 No.3, p. 284-290. https://doi.org/10.1097/EDE.obo13e3181d61f53

Jørgensen M.S., M. Larsen, M. Rosenstock (2005). Et læengere arbejdsliv Tilbagetrækningsordninger og arbejdspladsens muligheder. Socialforskningsinstituttet. 
Kadefors R., M. Albin, K. Nilsson (2014). Work life lenght in different occupations. Notat.

Kadefors R., K. Nilsson, L. Rylander, P.-O. Östergren, M. Albin (2017). Work life length in different occupations: A Swedish population study. Ageing \& Society. https://doi.org/10.1017/S0144686X17000083 (E-publ ahead of print).

Knardahl S., H.A. Johannessen, T. Sterud, M. Härmä, R. Rugulies, J. Seitsamo, V. Borg (2017). The contribution from psychological, social, and organizational work factors to risk of disability retirement: a systematic review with meta-analyses. BMC Public Health Vol, 17, No.176. https://doi.org/10.1186/s12889-017-4059-4

Kostøl A.R., M. Mogstad (2013). How financial incentives induce disability insurance recipients to return to work. Discussion papers no. 685. Oslo, National Bureau of Economic Research. https://doi.org/10.3386/w19016

Krekula C. (2009). Age coding: On age-based practices of distinction. International Journal for the Study of Ageing and Later Life Vol. 4 No. 2; p. 7-31. https://doi.org/10.3384/ijal.16528670.09427

Krekula C. (2010). Ålder som diskrimineringsgrund. I: Aktiva åtgärder för att främja lika rättigheter och möjligheter. SOU 2010 Vol. 7, p. 387-398.

Kristensen P., H.M. Gravseth, T. Bjerkedal (2010). Influence of early life factors on social inequalities in psychiatric outcomes among young adult Norwegian men. Eur J Public Health. Vol. 20 No. 5, p. 517-23. https://doi.org/10.1093/eurpub/ckq083

Kristensen T.S., M. Borritz, E. Villadsen, K.B. Christensen (2005). The Copenhagen Burnout Inventory: A new tool for the assessment of burnout. Work \& Stress: An International Journal of Work, Health \& Organisations Vol. 19 No.3, p. 192-207.

https://doi.org/10.1080/02678370500297720

Kristiansen J., R. Persson, S.P. Lund, H. Shibuya, P.M. Nielsen (2013). Effects of classroom acoustics and self-reported noise exposure on teachers' well-being. Environment and Behavior Vol. 45 No. 2, p. 283-300. https://doi.org/10.1177/0013916511429700

Krokstad S., R. Johnsen, S. Westin (2002). Social determinants of disability pension: a 10-year follow-up of 62 ooo people in a Norwegian county population. International Journal of Epidemiology Vol. 31 No. 6, p. 1183-1191. https://doi.org/10.1093/ije/31.6.1183

Labriola M., H. Feveile, K.B. Christensen, J. Strøyer, T. Lund (2009a). The impact of ergonomic work environment exposures on the risk of disability pension. Prospective results from DWECS/DREAM. Ergonomics Vol. 52 No. 11, p. 1419-1422.

https://doi.org/10.1080/00140130903067771

Labriola M., H. Feveile, K.B. Christensen, U. Bültmann, T. Lund (200gb). The impact of job satisfaction on the risk of disability pension. A 15-year prospective study. Scand $J$ Pub Health Vol. 37 No. 7, p. 778-8o. https://doi.org/10.1177/1403494809344103

Laaksonen M., N. Metsä-Simola, P. Martikainen, O. Pietiläinen, O. Rahkonen, R. Gould, T. Partonen, E. Lahelma (2012). Trajectories of mental health before and after old-age and disability retirement: a register-based study on purchases of psychotropic drugs. Scand J Work, Environ Health Vol. 38 No. 5, p. 409-417. https://doi.org/10.5271/sjweh.3290

Larsen M (2008). Does quality of work life affect men and women's retirement planning differently? Appl. Res. Qual. Life Vol. 3 No. 1, p. 23-42. https://doi.org/10.1007/s11482-0089045-7

Larsen M., H. Bach Bjerregaard, L.E. Sand (2011). 55-70 åriges forbliven på arbejdsmarkedet. Adfærd, forventninger, aftaler og kendskab til regler. Socialforskningsinstituttet 2011:13.

Larsen M., P.J. Pedersen (2013). To work, to retire - or both? Labor market activity after 6o. IZA J Euro Labor Studies Vol. 2 No. 21.

Larsen M., P.J. Pedersen (2016). - hvorfor ramte krisen ikke de ældres beskæftigelse i OECDlandene? Samfundsøkonomen 2016 Vol. 2, p. 49-55.

Lederne 2012. Seniorer på arbejdsmarkedet.

Lien O.C. (2014). Få bytter jobb etter fylte 50 år. Arbeid \& Velferd 2014 Vol. 1, p. 37-50.

LO (2016a). Flere gode år på arbejdsmarkedet. Stor gevinst ved at hindre nedslidning.

LO (2016b). Flere gode år på arbejdsmarkedet. Sen pension er svær med dårligt helbred. 
LO (2016c). Flere gode år på arbejdsmarkedet. Seniorpolitik bruges for lidt.

Lorentzen T. et al. (2006). Den nye staten: Omstillingens effekter på ansattes fravær og trygdemottak. Søkelys på arbeidsmarkedet Vol. 23 No. 2, p. 249-258.

Lund J., T. Bjerkedal (2001). Permanent impairments, disabilities and disability pensions related to accidents in Norway. Accident Analysis \& Prevention Vol. 33 No. 1, p. 19-30. https://doi.org/10.1016/S0001-4575(00)00011-7

Lund T., A. Csonka (2003). Risk factors in health, work environment, smoking status, and organizational context for work disability. Am J Ind Med Vol. 44 No. 5, p. 492-501.

https://doi.org/10.1002/ajim.10298

Lund T., E. Villadsen (2005). Who retires early and why? Determinants of early retirement pension among Danish employees 57-62 years of age. European Journal of Ageing Vol. 2 No. 4, p. 275-28o. https://doi.org/10.1007/s10433-005-0013-x

Lund T. L. Iversen, K.B. Poulsen (2001). Work environment factors, health, lifestyle and marital status as predictors of job changes and early retirement in physically heavy occupations. Am. J. Ind. Med. Vol. 40, p. 161-169. https://doi.org/10.1002/ajim.1084

Lund T., J. Pedersen, O.M. Poulsen (2006). Tilbagetrækning fra arbejde før pensionsalderen. Arbejdsmiljøinstituttet rapport.

Mehlum I.S. (2013). Betydningen av arbeidsmiljø for sosiale ulikheter i helse. Underlagsrapport til Sosial ulikhet i helse: En norsk kunnskapsoversikt. Statens arbeidsmiljøinstitutt.

Meng A. (2013). The Mechanisms and motivations behind older drivers' self-regulation of driving. PhD Thesis. University of Copenhagen, Department of psychology.

Midtsundstad T. (2001). Pensjonering i stat og skoleverk. Analyse av registerdata fra Statens Pensjonskasse 1996 og 1999. Fafo-notat 2001:01. Oslo, Forskningsstiftelsen Fafo.

Midtsundstad T. (2002a). AFP-pensjonisten: sliten-eller frisk og arbeidsfør? En analyse av tidlig pensjonering og bruk av AFP i privat sektor. Fafo-rapport 385. Oslo, Forskningsstiftelsen Fafo.

Midtsundstad T. (2002b). Tidlig pensjonering i stat og skoleverk. En analyse av registerdata fra Statens pensjonskasse for 2000. Fafo-notat 2002:12. Oslo, Forskningsstiftelsen Fafo.

Midtsundstad T. (2002C). Vi har ikke bruk for deg lenger... Tidligpensjonering og bruk av AFP blant ingeniører i privat sektor. Fafo-notat 2002:13. Oslo, Forskningsstiftelsen Fafo.

Midtsundstad T. (2002d). Tidlig pensjonering og seniorpolitiske utfordringer blant mellomledere og teknikere i privat sektor. Fafo-notat 2002:21. Oslo, Forskningsstiftelsen Fafo.

Midtsundstad T. (2003). Yrke bestemmer avgangen: En beskrivelse av tidlig pensjonering blant statsansatte. Søkelys på arbeidsmarkedet Vol. 1, p. 101-112.

Midtsundstad T. (2004). En beskrivelse av sykepleiernes pensjoneringsmønster i 2003 med utgangspunkt i registerdata fra KLP. Tabellnotat. Fafo-notat 2004:17. Oslo, Forskningsstiftelsen Fafo.

Midtsundstad T. (2005a). Ikke nødvendigvis sliten - en analyse av tidligpensjonering og seniorpolitikk i staten. Fafo-rapport 482. Oslo, Fafo Institutt for arbeidslivs- og velferdsforskning: p. 182.

Midtsundstad T. (2005b). Ikke nødvendigvis sliten... En analyse av AFP-pensjonering i staten. Søkelys på arbeidslivet Vol. 2, p. 217-232.

Midtsundstad T. (2005c). Virksomhetenes sosiale ansvar. I H. Torp (red.), Nytt arbeidsliv. Medvirkning, inkludering og belønning, Oslo: Gyldendal Akademisk.

Midtsundstad T. (2006). Pensjonering før fylte 67 år. Tidligpensjonering og bruk av AFP innen KS' tariffområde 2002-2004. Fafo-rapport 509. Oslo, Fafo Institutt for arbeidslivs- og velferdsforskning.

Midtsundstad T (2007a). Fra utstøting til inkludering? En kartlegging av norske virksomheters arbeidskraftstrategier overfor eldre arbeidstakere. Fafo-rapport 2007:37. Oslo, Fafo.

Midtsundstad T. (2007b). Vil arbeidslivet ha seniorene? En oversikt over norske virksomheters seniorengasjement. Søkelys på arbeidslivet Vol. 24 No. 1, p. 95-111.

Midtsundstad T. (2008). Virksomheten som sosialpolitisk aktør. Tidsskrift for Velferdsforskning Vol. 22 No. 1, p. 17-33. 
Midtsundstad T. (2009a). Går vi av tidlig for å pleie mor? Søkelys på arbeidslivet Vol. 26 No. 2, p. 137-252.

Midtsundstad T. (2009b). Bedre helse, mindre slit og mer familie. Delrapport 6 Liv og arbeid mulighetenes arbeidsliv for alle? Et prosjekt om forutsetningene for et bedre og lengre yrkesliv. Fafo-rapport 2009:16. Oslo: Fafo Institute for Labour and Social Research.

Midtsundstad T. (2011). Inclusive workplaces and older workers: an analysis of companies' investment in retaining senior workers. The International Journal of Human Resource Management Vol. 22 No. 6, p. 1276-1292. https://doi.org/10.1080/09585192.2011.559099

Midtsundstad T. (2014). Voksende seniorengasjement i norsk arbeidsliv. En virksomhetsundersøkelse fra 2013. Fafo-rapport 2014:30, Oslo, Fafo.

Midtsundstad T. (2015a). Tiltak for å holde på eldre arbeidstakere. I H. Dale-Olsen (red.), Norsk arbeidsliv i turbulente tider. Oslo: Gyldendal Akademisk.

Midtsundstad T. (2015b). IA som strategi for lengre yrkeskarrierer. En analyse av virksomhetenes seniorpolitikk og dens effekt på tidligpensjoneringen. Doktoravhandling. Fafo-rapport 2015:49.

Midtsundstad T., H. Bogen (2014). Active ageing policies between individual needs and collective goods. A study of active ageing policies and practices in Norway. Nordic Journal of Working Life Studies Vol 4 No. 2, p. 139-158. https://doi.org/10.19154/njwls.v4i2.3868

Midtsundstad T., H. Bogen (2011a). How the Worker Collective may Moderate Active Ageing Policy and its Outcomes', In R. Ennals and R. Salomon (eds.) Older Worker in a sustainable society, Labour, Education \& Society Vol 21. Frankfurt: Peter Lang Verlag.

Midtsundstad T., H. Bogen (2011b). Seniorpolitikk - behov for justering? Analyse av praksis i seks foregangskommuner. Søkelys på arbeidslivet Vol. 28 No. 1-2, p. 89-106.

Midtsundstad T., H. Bogen (2011C). Ulikt arbeid - ulike behov : seniorpolitisk praksis i norsk arbeidsliv. Fafo-rapport 2011: 10. Oslo, Forskningsstiftelsen FAFO: 170 p. : diagr.

Midtsundstad T., R.A. Nielsen (2013). Arbeid, pensjon eller begge deler? Fafo-rapport 2013:12. Oslo, Fafo.

Midtsundstad T., R.A. Nielsen (2014a). Arbeid og pensjon i kommunesektoren. Fafo-rapport 2014: forthcoming. Oslo, Fafo Institutt for arbeidslivs- og velferdsforskning.

Midtsundstad T, R.A. Nielsen (2014b). Do work-place initiated measures reduce sickness absence? Preventive measures and sickness absence among older workers in Norway. Scand J Publ Health Vol. 42 No 2, p. 207-214. https://doi.org/10.1177/1403494813510791

Midtsundstad T., Å. Hermansen, R.A. Nielsen (2012a). Effects of companies' initiatives to reduce early retirement among older workers. Nordic Journal of Working Life Studies Vol. 2 No.3, p. 89-108. https://doi.org/10.19154/njwls.v2i3.2365

Midtsundstad T., R.A. Nielsen (2016). Do workplace interventions reduce disability rates? Occup Med Vol. 66 No. 9, p. 691-697. https://doi.org/10.1093/occmed/kqw169. First published online: December 16, 2016.

Midtsundstad T., R.A. Nielsen, Å. Hermansen (2012b). Tilrettelegging og seniortitak - påvirker det kommuneansattes sykefravær og tidligpensjonering? Søkelys på arbeidslivet Vol. 29 No. 1, p. 130-150.

Midtsundstad T., R.A. Nielsen, Å. Hermansen (2013). Virksomhetenes seniortiltak. Har de effekt på seniorenes sykefravær og tidligpensjonering? Fafo-notat 2013:01. Oslo, Fafo Institutt for arbeidslivs- og velferdsstudier.

Myklebø S. (2011). Overgang til arbeid og aktivitet blant tidligere NAV-brukere. Report No. 3/2011. Oslo, Norwegian Labour and Welfare Administration (NAV).

Nielsen R.A. (2014). Tidligpensjonering i kommunal sektor. Tidligpensjonering innen KS' tariffområde 2002-2012. Fafo-rapport 2014:35. Oslo, Fafo.

Nielsen R.A. (2017). Pensjonsuttak før fylte 67 år. Tidligpensjonering og bruk av AFP innen KS' tariffområde 2002-2015. Fafo-rapport 2017:03. Oslo, Fafo.

Nielsen Breidahl K. (2011). Chap 10 in J.G. Andersen \& P.H. Jensen (eds). Tilbagetrækning fra arbejdsmarkedet - årsager og effekter. Bogforlaget Frydenlund. ISBN 978-87-7118-016-9. 
Nielsen R.A., T. Midtsundstad (2016). Virker tiltakene? Effektanalyser av virksomhetsinitierte tiltak på ansattes sykefravær og uførepensjonering. Fafo-notat 2016:12. Oslo, Fafo Institutt for arbeidslivs- og velferdsforskning.

Nielsen M.B., S. Knardahl S (2017). Does human resource primacy moderate the impact of psychological distress on subsequent risk for disability retirement? Scand J Work Environ Health Vol. 43 No. 2, p. 187-190. https://doi.org/10.5271/sjweh.3621

Nielsen M.L., R. Rugulies, L. Smith-Hansen, K.B. Christensen, T.S. Kristensen (2006). Psychosocial work environment and registered absence from work: Estimating the etiologic fraction. Am Jf Ind Med Vol. 49, p. 187-196. https://doi.org/10.1002/ajim. 20252

Nilsson E., K. Nilsson (2017). Time for Caring? Elderly care employees' occupational activities in the cross draft between their work priorities, "must-do's" and meaningfulness. International Journal of Care Coordination. (Online first) http://journals.sagepub.com/eprint/gZYkPOqDR8FTqYrRCUJc/full

Nilsson E., K. Nilsson K (2017). The transfer of knowledge between younger and older employees in the health- and medical care. - An intervention study. Journal of Social Sciences (accepted for publication 20170402). https://doi.org/10.4236/jss.2017.57006

Nilsson K. (2003). Arbetstillfredsställelse hos äldre läkare och sjuksköterskor. [Work satisfaction among older physician and nurses.] Malmö: Swedish National Institute of Working life, 2003. (in Swedish).

Nilsson K. (2003). Förlängt arbetsliv - En litteraturstudie av faktorer med betydelse för förlängt arbetsliv som alternativ till tidig pensionsavgång. [Extended working life - A literature review on factors important to an extended working life as an alternative to early retirement]. Malmö: Swedish National Institute of Working life, 2003. (in Swedish).

Nilsson K. (2005). Vem kan och vill arbeta till 65 år eller längre? En studie av anställda inom hälso- och sjukvården. [Who can and want to work until 65 years or beyond? A study with employed in health and medical care]. Arbete och hälsa Vol. 14, p. 1-35. https://gupea.ub.gu.se/bitstream/2077/4345/1/ah2005_14.pdf (in Swedish).

Nilsson K. (2005b). Pension eller arbetsliv? [Pension or working life?]. Malmö, Swedish National Institute in Working life, 2005. (in Swedish).

Nilsson K. (2006). Äldre medarbetares attityder till ett långt arbetsliv. Skillnader mellan olika yrkesgrupper inom hälso- och sjukvården. [Older workers attitude to an extended working life. Differences between occupations in health and medical care.] Arbetsliv i omvandling Vol. 10: p. 1-69 http://nile.lub.lu.se/arbarch/aio/2006/aio2006_10.pdf

Nilsson K. (2007). Chefers attityder till äldre medarbetare inom kommunen. [Municipal managers attitude to their older workers] Stockholm: Swedish National Institute of Working life, 2007 Vol. 4. (in Swedish).

Nilsson K (2007). Kön, arbetsliv och ålderspension. [Gender, working life and old age retirement.] In Kadefors R. (ed.) Uppdragsrapport till den svenska regeringen angående Den äldre arbetskraften. [Study commissioned by the Swedish government on The Older Workforce ]. Stockholm: Swedish National Institute of Working life. 2007. (in Swedish).

Nilsson K. (2007). Kunskapslabbet i Trelleborg - ett projekt om överföring av erfarenhetskunskap mellan kommun- och landstingsanställda samt mellan generationerna. [The Knowledge lab in Trelleborg - Experience knowledge transition project between generations in health care sectors.] Lund: FoU Skåne, 2007 Vol. 1. (in Swedish).

Nilsson K. (2011). Äldre lantbrukares arbetssituation och hälsa. [Older farmers work situation and health] Alnarp: Swedish University of Agricultural Sciences. 2011 Vol. 37. (In Swedish).

Nilsson K. (2011). Attitudes of managers and older employees to each other and the effects on the decision to extended working life. In Ennals R. Salomon RH. (eds.) Older Workers in a Sustainable Society. Labor, Education \& Society. Frankfurt: Peter Lang Verlag, 2011: p. 147-156.

Nilsson K. (2012). Why work beyond 65? Discourse on the decision to continue working or retire early. Nordic Journal of Working Life Studies Vol. 2 No. 3: p. 7-28.

https://doi.org/10.19154/njwls.v2i3.2361 
Nilsson K. (2013). To work or not to work in an extended working life? Factors in working and retirement decision. Doctoral Dissertation Series 2013:4. Faculty of Medicine, Lund University. https://lup.lub.lu.se/search/ws/files/3913230/3346493.pdf

Nilsson K. (2015). Kön och ålderspension - en tvärsnittstudie om skillnader mellan män och kvinnor i att kunna och vilja arbeta till 65 år eller längre. Arbets- och miljömedicin, Lunds universitet: Rapport nr 4/2015.

Nilsson K. (2016a). Conceptualisation of ageing in relation to factors of importance for extending working life - a review. Scand J Pub Health Vol. 44, p. 490-505. https://doi.org/10.1177/1403494816636265

Nilsson K. (2016b). Interventions to reduce injuries among older workers in agriculture: A review of evaluated intervention projects. WORK: A Journal of Prevention, Assessment, and Rehabilitation Vol. 55 No.2, p. 471-48o. http://content.iospress.com/articles/work/wor2407; https://doi.org/10.3233/WOR-162407

Nilsson K. (2016). The ability and desire to extend working life. In Vingård E. (ed.) Healthy workplaces for men and women in all ages. Knowledge compilation 2016:8. Stockholm: Arbetsmiljöverket, 2017.

Nilsson K. (2017). Sustainable working life for all ages - The swAge model. http://www.swAge.org/ (Cited 201701 18).

Nilsson K. (2017). Bäst före datum på arbetskraften? - olika åldersbegrepps betydelse för äldre i arbetslivet [Best before date on the workforce? - Different age concepts important for older people in the workplace] In C. Krekula C. B. Johansson (eds.). Introduktion till kritiska åldersstudier. Lund: Studentlitteratur, 2017.

Nilsson K. (2017). Active and healthy ageing at work. - A qualitative study with employees 5563 years and their managers. Journal of Sociel Science (accepted for publication 20170420). https://doi.org/10.4236/jss.2017.57002

Nilsson K. (2017). Motivation and work environmental influence on seniors' attitudes to an extended working life or to retire. A cross sectional study with employees 55-74 years of age. Journal of Social Sciences (accepted for publication 20170320). https://doi.org/10.4236/jss.2017.57003

Nilsson K. (2017). Managers' attitudes to their older employees - a cross-sectional study. WORK: A Journal of Prevention, Assessment, and Rehabilitation (accepted for publication 20170505).

Nilsson K, A.R. Hydbom, L. Rylander (2011). Factors influencing the decision to extend working life or retire. Scand J Work, Environ Health Vol. 37 No. 6, p.473-480. https://doi.org/10.5271/sjweh.3181

Nilsson K., S. Pinzke (2011). Äldre lantbrukares olycksrisker. [Injury risk among older farmers.] Alnarp: Swedish University of Agricultural Sciences, 2011 Vol. 22. (in Swedish).

Nilsson K, S. Pinzke (2012). Occupational Accidents Among Elderly Farmers in Sweden. Work: A Journal of Prevention, Assessment and Rehabilitation Vol. 41, p. 5324-5326.

Nilsson K., S. Pinzke, P. Lundqvist (2010). Occupational Injuries to Senior Farmers in Sweden. Journal of Agricultural Safety \& Health Vol. 16 No. 1, p. 19-29. https://doi.org/10.13031/2013.29246

Nilsson K., A. Rignell-Hydbom, L. Rylander (2016b). How is self-rated health and diagnosed disease associate with early or deferred retirement: a cross sectional study with employees aged 55-64. BMC Public Health Vol. 16 No. 886. DOI 10.1186/s12889-016-3438-6, DOI 10.1186/s12889-016-3438-6. https://www.ncbi.nlm.nih.gov/pmc/articles/PMC5000415/

Nilsson K., P-O Östergren, R. Kadefors, M. Albin (2016a). Has the participation of older employees in the workforce increased? Study of the total Swedish population regarding exit working life. Scand J Public Health Vol. 44, p. 506-516.

https://doi.org/10.1177/1403494816637262

NOA. The National Surveillance System for Work Environment and Occupational Health. STAMI, Norway. 
Nordenmark M., M. Stattin (2009). Psychosocial wellbeing and reasons for retirement in Sweden. Ageing and Society Vol. 29 No. 3, p. 413-430.

https://doi.org/10.1017/S0144686X08008179

Nylén L., M. Torgén (2002). Under vilka förhållanden vill äldre personer yrkesarbeta?

Arbetslivsrapport 2002 Vol. 2. Stockholm: Arbetslivsinstitutet.

OECD (2011). Pension at a Glance - retirement income systems in OECD and G2o countries. Paris, OECD Publishing.

OECD (2015a). OECD Recommendation on the Council on Ageing and Employment Policies.

OECD (2015b). OECD Statistics. Employment rate of 55-64 year-olds $Q_{4} 2015$.

OECD (2015C). Average effective age of retirement versus the normal retirement age, 2009-2014.

Olesen K, R. Rugulies, N. Hulvej Rod, J.P. Bonde (2014). Does retirement reduce the risk of myocardial infarction? A prospective registry linkage study of 617.511 Danish workers. Inter J Epidem Vol. 43 No. 1, p. 160-167. https://doi.org/10.1093/ije/dyt26o

Olesen K., N. Hulvej Rod, I.E.H. Madsen, J.P. Bonde, R. Rugulies (2015). Does retirement reduce the risk of mental disorders? A national registry-linkage study of treatment for mental disorders before and after retirement of 245,082 Danish residents. Occ Environ Med Vol. 72 No. 2, p. 366-372. https://doi.org/10.1136/oemed-2014-102228

Ortega A., K.B. Christensen, A. Hogh, R. Rugulies, V. Borg (2011). One-year prospective study on the effect of workplace bullying on long-term sickness absence. Journal of Nursing Management Vol. 19, p. 752-759. https://doi.org/10.1111/j.1365-2834.2010.01179.X

Persson R., J. Kristiansen, S.P. Lund, H. Shibuya, P.M. Nielsen (2013). Classroom acoustics and hearing ability as determinants for perceived social climate and intentions to stay at work.

Noise \& Health Vol. 15 No. 67, p. 446-53. https://doi.org/10.4103/1463-1741.121254

Pinzke S., K. Nilsson, P. Lundqvist (2014). Farm tractors on Swedish public roads--age-related perspectives on police reported incidents and injuries. Work Vol. 49 No. 1, p. 39-49.

Poulsen O.M., V. Borg, N. Fallentin, T. Lund, C. Nørregaard (2006). Arbejdsbetingelser og fastholdelse af seniorer - Status over den eksisterende viden. Arbejdsmiljøinstituttet rapport.

Rege M., K Telle, M. Votruba (2009). The effect of plant downsizing on disability pension utilization. Journal of the European Economic Association Vol. 7 No. 4, p. 754-785.

https://doi.org/10.1162/JEEA.2009.7.4.754

Reichborn-Kjennerud K., M. Gamperiene, A.I. Hilsen (2011). "Make me an offer I Can't Refuse" Do Extra Days off Contribute to Seniors Staying at Work longer? Older Workers in a Sustainable Society, Peter Lang Publishing Group.

Røed K, E. Fevang (2007). Organisational change, absenteeism, and welfare dependency. Journal of Human Resources Vol. 42 No. 1, p. 156-193. https://doi.org/10.3368/jhr.XLII.1.156

Samuelsson $\AA_{\text {, }}$ A. Ropponen, K. Alexanderson, P. Svedberg (2013). Psychosocial working conditions, occupational groups, and risk of disability pension due to mental diagnoses: $A$ cohort study of 43000 Swedish twins. Scand J Work, Environ Health Vol. 39 No. 4, p. 351-360. https://doi.org/10.5271/sjweh.3338

Sejbaek C.S., M.A. Nexo, V. Borg (2013). Work-related factors and early retirement intention: a study of the Danish eldercare sector. European Journal of Public Health Vol. 23 No. 4, p. 611-616. https://doi.org/10.1093/eurpub/cks117

Sell L. (2009). Predicting long-term sickness absence and early retirement pension from selfreported work ability. Int Arch Occ Environ Health Vol 82 No. 9, p. 1133-1138. https://doi.org/10.1007/s00420-009-0417-6

Sigvaldason K, F. Tryggvason, G. Petursdottir, H. Snorrason, B. Baldursson, B. Mogensen (2010). Fatal accidents and non-fatal injuries amongst seamen in Iceland 2001-2005. Icel Med J Vol. 96, p. 29-35.

Sjösten N., H. Nabi, H. Westerlund, A. Singh-Manoux, J.F. Dartiques, M. Goldberg, M. Zins, T. Oksanen, P. Salo, J. Pentii, M. Kivimäki, J. Vahtera (2010). Influence of retirement and work stress on headache prevalence: A longitudinal modelling study from GAZEL Cohort Study. Cephalagia Vol. 31 No. 6, p. 696-705. https://doi.org/10.1177/0333102410394677 
Snartland V., E. Øverbye (2003). Skal jeg bli eller skal jeg gå? Pensjonsforventninger hos lærere og ingeniører. NOVA-rapport 21/2003. https://doi.org/10.7577/nova/rapporter/2003/21

Soidre T. (2005). Retirement-age preferences of women and men aged 55-64 years in Sweden. Ageing and Society 2005, p. 943-963. https://doi.org/10.1017/S0144686X05004216

Solem P.E. (2010). Eldres posisjon i arbeidslivet ved konjunkturomslag. Oslo, Norsk institutt for forskning om oppvekst, velferd og aldring. https://doi.org/10.7577/nova/rapporter/2010/5

Solem P.E. (2012). Possible Effects of the Financial Crisis on Managers' Attitudes to Older Workers. Nordic Journal of Working Life Studies Vol. 2 No. 3, p. 129-142.

https://doi.org/10.19154/njwls.v2i3.2367

Solem P.E., M. Nicolaisen, H. Finseraas (2008). Dårlig fysisk helse - ingen hindring for å jobbe? Samfunnsspeilet 5/6, 2008. Oslo: Statistic Norway (Statistisk sentralbyrå).

Solem P.E., R.J. Mykletun (2009). Endringer for seniorer i arbeidslivet fra 2003 til 2008. NOVArapport 20/2009. Oslo, Norsk institutt for forskning om oppvekst, velferd og aldring: $181 \mathrm{p}$. : diagr.

Solem P.E., A. Syse, T. Furunes, R.J. Mykletun, A.H. (2014/2016). To leave or not to leave: retirement intentions and retirement behaviour. Ageing \& Society Vol 36. No. 2, p. 259-281. On-line 22 October 2014.

Stattin M. (1998). Yrke, yrkesförändring och utslagning från arbetsmarknaden - en studie av relationen mellan förtidspension och arbetsmarknadsförändring. PhD thesis in sociology. Umeå University.

Stattin M. (2005). Retirement on grounds of ill health. Occ Environ Med Vol. 62, p. 134-139. https://doi.org/10.1136/oem.2004.015669

Sterud T. (2013). Work-related psychosocial and mechanical risk factors for work disability: a 3year follow-up study of the general working population in Norway. Scand J Work, Environ Health Vol. 39 No. 5, p. 468-476. https://doi.org/10.5271/sjweh.3359

Sterud T., H.A. Johannessen (2014). Do work-related mechanical and psychosocial factors contribute to the social gradient in long-term sick leave: a prospective study of the general working population in Norway. Scand J Publ Health Vol. 42 No. 3, p.329-334. https://doi.org/10.1177/1403494814521506

Støver M., K. Pape, R. Johnsen, N. Fleten, E.R. Sund, S.O. Ose, J.H. Bjørngaard (2013). Work environment and disability pension - an 18-year follow-up study in a Norwegian working population. Scand J Publ Health Vol. 41 No. 6, p. 587-596.

https://doi.org/10.1177/1403494813486965

Syse A, M. Veenstra, T. Furunes, R.J. Mykletun, P.E. Solem (2005). Changes in Health and Health Behavior Associated With Retirement, Journal of Aging and Health 2005, s. 1-29. https://doi.org/10.1177/0898264315624906

Thielen K., E. Nygaard, F. Diderichsen (2009). Smerter i bevægeapparatet og modificerende faktorer for tidlig tilbagetrækning fra arbejdsmarkedet. Rapport til Arbejdsmiljøforskningsfonden. https://doi.org/10.1093/eurpub/ckto11

Thielen K., E. Nygaard, I. Andersen, F. Diderichsen. Employment consequences of depressive symptoms and work demands individually and combined. Eur J Publ Health Vol. 24, p. 34-39.

Thorsen S.V., K. Løngård, J. B. Bjørner (2011). Fastholdelse af seniormedarbejdere på arbejdsmarkedet. NFA notat 2011.

Thorsen S.V., R. Rugulies, K. Løngård, V. Borg, K. Thielen, J.B Bjørner (2012). The association between psychosocial work environment, attitudes towards older workers (ageism) and planned retirement. Int Arch Occup Environ Health Vol. 85 No. 4, p. 437-335. https://doi.org/10.1007/s00420-011-0689-5

Thorsen S.V., P.H. Jensen, J.B. Bjørner (2016). Psychosocial work environment and retirement age: a prospective study of 1876 senior employees. Int Arch Occup Environ Health Vol. 89, p. 891-900. https://doi.org/10.1007/s00420-016-1125-7

Thorlacius S., S. Olafsson (2008). Fluctuations in unemployment and disability in Iceland 19922006. The Icelandic Medical Journal 2008: http://www.laeknabladid.is/2008/03/nr/3100). 
Thorlacius S., S.B. Stefansson, S. Olafsson, K. Tomasson K. (2010). Increased Incidence of Disability due to Mental and Behavioural Disorders in Iceland 1990-2007. Journal of Mental Health Vol. 19 No. 2, p. 176-83. https://doi.org/10.3109/09638230902968316

Tofteng M. (red.) (2016). Seniorers mobilitet på arbeidsmarkedet. Rapport nr. 50-2016. Oslo: Samfunnsøkonomisk Analyse AS.

Tofteng M., T. Midtsundstad, R. Bjørnstad (2016). Seniorers mobilitet på arbeidsmarkedetsammendragsnotat. Rapport nr. 51-2016. Oslo: Samfunnsøkonomisk Analyse AS.

Tüchsen F., K.B. Christensen, T. Lund, H. Feveile (2008). A 15-year prospective study of shift work and disability pension. Occup Environ Med Vol. 65, p.283-285.

https://doi.org/10.1136/oem.2007.036525

Tüchsen F., H. Feveile, K.B. Christensen, N. Krause (2010). The impact of self-reported exposure to whole-body-vibrations on the risk of disability pension among men: a 15 year prospective study. BMC Public Health 2010 Vol. 10 No. 305. http://dx.doi.org/10.1186/1471-2458-10-305

Tüchsen F., K.B. Christensen, H. Feveile, J. Dyreborg (2009). Work injuries and disability. J Safety Res Vol. 40 No.1, p. 21-24. https://doi.org/10.1016/j.jsr.2008.10.012

Vestad O.L. (2013). Labour supply effects of early retirement provision. Labour Economics Vol. 25, p. 98-109. https://doi.org/10.1016/j.labeco.2013.04.001

Wang M., K.S. Shultz (2010). Employee Retirement: A Review and Recommendations for Future Investigation. Journal of Management Vol. 36 No. 1, p. 172-206. https://doi.org/10.1177/0149206309347957

Welin L., L. Wilhelmsen (2013). Därför vill 1943 års män arbeta vidare efter 65 års ålder. Läkartidningen 2013; 110:CFI7.

Westerlund H., J. Vahtera, J.E. Ferrie, A. Singh-Manoux, J. Pentii, M. Melchior, C. Leineweber, M. Jokela, J. Siegrist, M. Goldberg, M. Zins, M. Kivimäki (2010). Effect of retirement on major chronic conditions and fatigue: French GAZEL occupational cohort study. British Medical Journal 2010. No. 341:c6149. https://doi.org/10.1136/bmj.c6149

Winge S., B.A. Mostue, H.M. Gravseth (2015). Skader i bygg og anlegg: Utvikling og problemområder. KOMPASS Tema nr. 4, 2015. Trondheim: Direktoratet for arbeidstilsynet.

Work and Health 2014 - In Danish $\square$ Arbejde og Helbred 2014. http://www.arbejdsmiljoforskning.dk/da/arbejdsmiljoedata/arbejdsmiljoe-og-helbred-2014

Zielke Schaarup J. (2009). Tilbagetrækningsalderen 1992-2008. Forsikring \& Pension Analyserapport 2009:3. 



\section{Sammenfatning på dansk}

Tidlig tilbagetræden fra arbejdsmarkedet skyldes sjældent arbejdsmiljøet alene idet beslutningen om tilbagetræden fra arbejdsmarkedet eller om at fortsætte med at arbejde påvirkes af mange andre faktorer på mikro- (individuelt helbred, økonomi etc.), meso- (arbejdspladsen, familie og tætte sociale netværk) og makroniveau (det sociale sikkerhedsnet, lovgivning og regulativer på arbejdsmarkedet). Denne problematik illustreres tydeligt i det teoretiske grundlag udarbejdet af Nilsson (2016) (figur 1). To væsentlige perspektiver gør sig gældende i forbindelse med ældre arbejdstageres tilbagetræden fra arbejdsmarkedet:

- "Udsatte" ældre arbejdstagere. Dette perspektiv fokuserer på en større gruppe af ældre arbejdstagere med begrænsede ressourcer på grund af nedslidning, helbredsproblemer og manglende kompetencer, og som har et særligt behov for "beskyttelse" og arbejdstilpasning, hvis de skal fastholdes på arbejdsmarkedet.

- Ressourcestærke ældre arbejdstagere. Perspektivet fokuserer på en gruppe ældre arbejdstagere med fremragende helbred og mange kompetencer.

Arbejdspladserne anser dem som værende en aktiv og produktiv ressource særligt hvis man kan udnytte deres store erfaring. For at kunne forlænge arbejdslivet for denne gruppe arbejdstagere, er man fra arbejdspladsens side nødt til at fokusere på at gøre arbejdet mere attraktivt.

I samtlige de fire nordiske lande - Danmark, Island, Norge og Sverige - er der markante forskelle i alderen for tilbagetræden, og disse forskelle kan til en vis udstrækning tilskrives historiske og nuværende kulturforskelle samt forskellige pensionssystemer, arbejdsmarkedsregulativer og politikker. En markant forskel er, at Danmark tidligere har haft en kultur for tidlig tilbagetræden fra arbejdsmarkedet, som har været benyttet til at reducere arbejdskraften i perioder med høj arbejdsløshed. Dermed er der opstået en kultur i Danmark, hvor tidlig tilbagetræden både kan forventes og er socialt acceptabelt. I modsætning til de andre tre lande, som har en tilbagetrædelseskultur, hvor man meget aktivt har bekæmpet arbejdsløsheden indenfor alle aldersgrupper. Sikkerhed i ansættelsen er lav i Danmark men høj i de andre lande, og dette bidrager sikkert til, at arbejdsløshedsprocenten blandt ældre arbejdstagere er høj i Danmark. Udtræden fra arbejdsmarkedet som følge af invalidepension (førtidspension) forekommer sjældent $\mathrm{i}$ Danmark og Island, men er hyppigt forekommende i Norge og Sverige. Eldre arbejdstagere med helbredsproblemer i Danmark og Island har tilsyneladende ikke de samme muligheder for invalidepension/førtidspension, og dermed bliver de i stedet tvunget ud $i$ en frivillig tilbagetrædelsesordning fra arbejdsmarkedet ( $f x$ efterløn $i$ Danmark). Efter at Sverige for nyligt gjorde det sværere at opnå invalidepension, er den frivillige tilbagetræden fra arbejdsmarkedet steget i Sverige. 


\section{Arbejdsmiljøets betydning for tilbagetræden fra arbejdsmarkedet}

Beregninger af den andel af tilbagetræden fra arbejdsmarkedet, som skyldes selve arbejdsmiljøet, er kun lavet i forhold til overgang til invalidepension/førtidspension henholdsvis langvarigt sygefravær, men ikke i forhold til overgang til efterløn eller anden frivillig tidlig tilbagetræden fra arbejdsmarkedet. I disse beregninger har der været fokus på betydningen af skadelige risikofaktorer i arbejdsmiljøet, og der mangler viden om den relative betydning af andre arbejdsmiljømæssige prædiktorer for frivillig tidlig tilbagetræden fra arbejdsmarkedet, $\mathrm{fx}$ jobtilfredshed og motivation. En stor del af førtdispension i Danmark skyldes høje fysiske arbejdskrav (21\% for mænd og $34 \%$ for kvinder), og to psykosociale arbejdsmiljøfaktorer (beslutningskompetence og variation) kan hver forklare 10-15\% af risikoen for overgang til førtidspension. Lignende resultater er observeret i Norge, hvor fem psykosociale og otte ergonomiske risikofaktorer i arbejdsmiljøet kan forklare $45 \%$ af tilbagetræeden til invalidepension. Endelig kan $30 \%$ af langtidssygemeldinger tilskrives det psykosociale arbejdsmiljø i Danmark, og mellem 31$54 \%$ af den sociale ulighed i langtidssygemeldinger i Norge kan tilskrives arbejdsmiljøet.

\section{Arbejdsmiljøprædiktorer for tilbagetræden fra arbejdsmarkedet}

Der har været lavet flere detaljerede undersøgelser af sammenhænge mellem forskellige arbejdsmiljømæssige faktorer og tilbagetræden fra arbejdsmarkedet i de nordiske lande, og sammenlignelige resultater er blevet opnået på tværs af landene. Vi mener derfor, at dokumentation fra ét af landene må anses som værende valid for de øvrige nordiske lande.

Vores konklusion er, at følgende arbejdsmiljøprædiktorer for tidlig tilbagetræden fra arbejdsmarkedet er veldokumenteret: arbejdsulykker, helkropsvibrationer, fysiske arbejdskrav (fx fysisk hårdt arbejde, tunge løft, vedvarende opretstående arbejde), kvantitative arbejdskrav ( $\mathrm{fx}$ arbejdstempo og tidspres), jobkontrol/selvstændighed/ indflydelse på arbejde, støtte fra ledere, arbejdskonflikter og mobning/chikane, jobtilfredshed og aldersdiskrimination. Derudover findes der en vis dokumentation for, at manglende mulighed for kompetenceudvikling er en prædiktor. Endelig er forskningen i de nordiske lande begrænset med hensyn til betydningen af kemiske arbejdsmiljøfaktorer, støj, skifteholdsarbejde, kollegial støtte, engagement i arbejde og frygt for reorganisering i forhold til tidlig tilbagetræden fra arbejdsmarkedet.

Der findes en stærk social gradient i tidlig tilbagetræden fra arbejdsmarkedet i alle de nordiske lande; og socialklasse, helbred og arbejdsmiljø er nært forbundne. Effekter af nylige og mere restriktive velfærdssystemer ( $f x$ mere begrænset adgang til invalidepension) $\mathrm{i}$ forhold til forskellige socialklasser (skævhed i balancen mellem helbred og arbejdsmiljø) har ikke været undersøgt tilstrækkeligt detaljeret. 


\section{Sammenligning af arbejdsmiljøet blandt ældre arbejdstagere i de nordiske lande}

Nationale undersøgelser af arbejdsmiljø og helbred gennemføres i både Danmark, Island, Norge og Sverige. Når data fra de fire lande sammenlignes findes der ligheder, men også markante forskelle.

ÆEldre ufaglærte kvinder i Danmark rapporterer, at de i højere grad end mænd udsættes for ensidigt, gentaget arbejde, hvorimod ufaglærte kvinder og mænd i både Norge og Sverige rapporterer, at de i næsten samme grad udsættes for ensidigt, gentaget arbejde. AEldre ufaglærte kvinder i både Norge og Sverige rapporterer mindre udsættelse for hårdt fysisk arbejde (særligt lavt i Sverige), mindre tunge løft (særligt lavt i Norge), og mindre udsættelse for arbejde med hænderne løftet over skulderhøjde end ældre ufaglærte mænd, hvorimod det modsatte er tilfældet i Danmark. Det fysiske arbejdsmiljø blandt ældre ufaglærte kvinder i Danmark lader til at være mere krævende, end det er tilfældet for ældre ufaglærte kvinder i både Norge og Sverige.

Eldre arbejdstagere i Danmark og Sverige rapporterer næsten samme høje udsættelse for arbejde i akavede stillinger og arbejde med begge hænder løftet over skulderhøjde. Disse fysiske eksponeringer overstiger langt de samme eksponeringer blandt ældre arbejdstagere i Norge. AEldre mænd i Danmark og Sverige er ligeledes mere udsat for vibrationer og et højt støjniveau end ældre arbejdstagere i Norge.

Ældre arbejdstagere i Danmark rapporterer langt flere arbejdsulykker end ældre mænd i Norge og Island. I Sverige rapporteres arbejdsulykker og -skader generelt hyppigere blandt ældre arbejdstagere end blandt yngre aldersgrupper. Der er ligeledes forskel på arbejdsskaderne mellem de forskellige sektorer, hvilket sandsynligvis skyldes, at pensionsalderen varierer i de forskellige sektorer. Andelen af arbejdsskader med dødeligt udfald er højest blandt ansatte indenfor landbrug samt skovarbejdere i Sverige.

En langt større andel af ældre arbejdstagere i Danmark udsættes for mobning/chikane end det er tilfældet i Sverige (mellem) og Norge (meget lav). ÆEldre arbejdstagere i Norge får mere støtte og hjælp fra deres nærmeste leder, end det er tilfældet for ældre arbejdstagere i Sverige og Danmark. På den anden side set, så oplever ældre arbejdstagere i Sverige og Danmark, at de mere kontrol og indflydelse over, hvordan deres arbejdsopgaver skal udføres, end det er tilfældet blandt ældre arbejdstagere i Norge.

Alt taget i betragtning, ser det ud til, at det fysiske og det psykosociale arbejdsmiljø blandt ældre arbejdstagere i Norge generelt er bedre end det er tilfældet for ældre arbejdstagere i Sverige og Danmark, men ældre arbejdstagere i Norge har mindre kontrol og indflydelse i arbejdet.

\section{Effekterne af arbejdspladsinterventioner for at øge fastholdelse af ældre arbejdstagere på arbejdsmarkedet}

I både Danmark og Norge rapporterer mindre end halvdelen af arbejdspladserne, at de laver praktiske foranstaltninger for at fremme fastholdelsen af ældre arbejdstagere på arbejdsmarkedet. Oftest sigter arbejdspladsens seniorpolitik og aktiviteter mod at 
tilbyde muligheden for, at ældre arbejdstagere kan trappe ned og opnå en gradvis tilbagetræden fra arbejdsmarkedet. Aktiviteterne består hovedsagligt af en form for fleksible arbejdstider, arbejdstidsnedsættelse, ret til flere ferie- eller orlovsdage samt bonusordninger. Det forekommer mere sjældent, at aktiviteterne omfatter mindre belastende arbejde, forbedret ergonomi eller kompetenceudvikling. I Norge har enkelte undersøgelser systematisk evalueret effekterne af virksomheders seniorpolitik og -aktiviteter med henblik på at øge fastholdelsen af ældre arbejdstagere på arbejdsmarkedet. Undersøgelserne fandt generelt, at de interventioner, som norske virksomheder tilbød, har begrænset effekt på tidlig tilbagetræden fra arbejdsmarkedet samt på sygefravær. Imidlertid viste de norske undersøgelser, at virksomhedsinterventioner målrettet ansatte med helbredsproblemer og nedsat arbejdskapacitet reducerer risiko for overgang til invalidepension, og tilbud om ekstra fridage og bonusordninger kunne $i$ en vis (mindre) grad reducere ønske om frivillig tidlig tilbagetræden fra arbejdsmarkedet. De fleste arbejdspladser i Sverige har ikke nogen politik med henblik på fastholdelse af ældre arbejdstagere. Kun $5 \%$ af de kommunale ledere i Sverige rapporterede, at de havde indført foranstaltninger med henblik på at fastholde ældre arbejdstagere i deres respektive organisationer. De ledere, som anførte, at de havde indført foranstaltninger, beskrev imidlertid disse som værende sundheds- og fitnessaktiviteter, projekter for kompetenceoverdragelse, mulighed for ældre arbejdstagere at gå på nedsat tid, samt særlige mentorordninger.

Selv om det ikke er lykkedes at påvise generelle effekter, udelukker det ikke, at positive effekter kan forekomme blandt nogle ældre arbejdstagere på nogle arbejdspladser. Der findes mange "case stories" i de nordiske lande, hvor arbejdspladserne oplyser, at de har haft succes med at fastholde ældre arbejdstagere.

Selv om meget tyder på, at et godt arbejdsmiljø er af afgørende betydning for fastholdelse af ældre arbejdstagere, er den eksisterende viden sparsom med hensyn til effekten af at forbedre arbejdsmiljøet på fastholdelse af ældre arbejdstagere. Den eksisterende viden antyder, at der er et stort potentiale i at udvikle arbejdspladsinterventioner, som kombinerer forebyggelse af risikofaktorer i arbejdsmiljøet ( $f x$ risikofaktorer ifm ulykker, hårdt arbejde/høje fysiske arbejdskrav, kvantitative arbejdskrav, arbejdskonflikter og mobning/chikane samt aldersdiskrimination) med en indsats for øget jobtilfredshed gennem mere kontrol/indflydelse, flere udviklingsmuligheder og mere anerkendelse fra ledelsen.

\section{Forskningsbehov}

Projektet har identificeret forskningsbehov knyttet til følgende, overordnede temaer:

- Opnåelse af en bæredygtig arbejdslivsbalance for alle. Det er nødvendigt, at der forskes mere i effektive arbejdspladspolitikker og -interventioner for at opnå en "bæredygtig" fastholdelse af ældre arbejdstagere. Særligt er det nødvendigt med mere viden om ældre, ufaglærte kvinder, som fastholdes i jobs med fysisk høje krav ( $f x$ plejesektoren samt service- og rengøringssektoren). Dertil kommer, at 
immigranter ofte i højere udstrækning har fysisk krævende arbejde end hvad man umiddelbart ville forvente ud fra deres uddannelsesniveau. Den eksisterende viden om, hvordan man kan forhindre førtidig tilbagetræden fra arbejdsmarkedet blandt ældre immigrantarbejdere er sparsom. Endelig forventes andelen af ældre arbejdstagere med funktionsbegrænsende kroniske sygdomme at stige i fremtiden. Det er derfor nødvendigt at finde ud af, hvordan arbejdet kan tilpasses, så det kan rumme et stigende antal ældre arbejdstagere med kronisk sygdom.

Der er behov for nye arbejdspladsinterventioner, der kombinerer forebyggelse af arbejdsmiljørisikofaktorer og aldersdiskrimination med indsatser for at øge jobtilfredsheden blandt medarbejderne. Endelig er der stort behov for mere "fra forskning til praksis" om, hvordan viden omkring effektive interventioner bedst formidles til arbejdspladser.

- Langsigtede konsekvenser af et forlænget arbejdsliv. For lavt-uddannede arbejdstagere med hårdt fysisk arbejde er det nødvendigt at skabe mere viden om de eventuelle negative konsekvenser, der kan opstå ved at de udsættes for denne type af arbejde i et længere arbejdsliv. Evalueringer af arbejdspladspolitikker og interventioner bør ikke kun fokusere på arbejdsfastholdelse ( $f x$ forventet og aktuelle tilbagetrædelsesalder), men også på arbejdstagerens helbred og trivsel under det forlængede arbejdsliv og efter tilbagetræden fra arbejde. I denne sammenhæng mangler viden om betydningen af gentagne overgange mellem forskellige sociale ydelser (arbejdsløshed, sygefravær, kontakthjælp, and sociale ydelser) inden tilbagetræden fra arbejdsmarkedet. Teoretisk set fører ændringer af pensionssystemet - ved bl.a. at begrænse muligheden for at få førtidspension ikke nødvendigvis til, at andelen af ældre arbejdstagere i beskæftigelse stiger. Alternativt kan en stigning i overgangen til forskellige sociale ydelser opstå særligt for ældre arbejdstagere med lav arbejdsmarkedsmobilitet som følge af manglende uddannelse og/eller kroniske sygdom.

- Den dynamiske tilbagetrædelsesproces. Indtil videre har de fleste undersøgelser betragtet tilbagetræden fra arbejdsmarkedet som en enkelt og afsluttet hændelse, og der tages ikke hensyn til, at beslutningen om tilbagetræden samt selve tilbagetrædelsesprocessen kan tage adskillige år. Dette nødvendiggør inddragelse af et længere livsforløbsperspektiv med fokus på arbejdsevne og arbejdsholdninger, og hvorledes disse ændres over tid, samt hvordan ældre arbejdstagere gradvist tilpasser sig den fremtidige pensionisttilværelse. Det er ligeledes nødvendigt med mere viden om, hvordan helbred, trivsel, livskvalitet og attituder ændrer sig i løbet af tilbagetrædelsesprocessen. Endelig er det nødvendigt med mere viden om de mulige positive effekter af overgang til frivilligt nedsat arbejdstid i forbindelse med delvis tilbagetræden fra arbejdsmarkedet.

- Arbejdspladsperspektivet. Mindre end halvdelen af arbejdspladserne (i Danmark og Norge) gennemfører praktiske indsatser for at fremme fastholdelsen af ældre arbejdstagere. Selv om der i Norge er opbygget en vis viden om motivation for og effekter af disse indsatser, er der et stort behov for mere viden i Danmark, Island og Sverige om motiver og arbejdspladsperspektiver, fx: hvorfor har nogle 
arbejdspladser - men ikke alle - besluttet at rekruttere og/eller fastholde ældre arbejdstagere? Hvilke typer af ældre arbejdstagere tilbydes indsatser mhp. seniorfastholdelse og hvorfor? Der mangler i særdeleshed viden om de aktuelle behov hos små og mellemstore virksomheder, og hvordan disse behov kan imødekommes. Potentielt er der nogle arbejdspladser, som har betydningsfulde "case stories", fx indenfor engrosvirksomheder og byggemarkeder, og som aktivt har rekrutteret seniormedarbejdere med henblik på at udnytte disses ekspertise. Men disse "case stories" har ikke været beskrevet systematisk, og den nuværende viden om effekterne af de gennemførte indsatser er sparsom. Endelig er den praktiske brug af forskningsbaseret viden på arbejdspladserne meget begrænset. Det kan meget vel være, at mange arbejdspladser ikke besidder de nødvendige ressourcer til at opnå tilstrækkelig med viden, der kan informere og støtte deres seniorpolitik og praktiske indsatser. Manglende viden kan være en vigtig barriere for opnåelse af et bæredygtig forlænget arbejdsliv - særligt på små og mellemstore virksomheder. Derfor er der et stort behov for en mere effektiv måde, hvorpå man kan omsætte opnået viden fra forskning til praksis.

- Bekæmpelse af aldersdiskrimination. Aldersdiskrimination findes i alle de nordiske lande. Den mest udbredte form for aldersdiskrimination er, at ældre arbejdstagere har meget begrænsede muligheder for at få et nyt arbejde, hvis de bliver arbejdsløse; og dermed fastholdes de enten i et arbejde, hvor kravene overstiger deres formåen eller også tvinges de til tidlig tilbagetræden fra arbejdsmarkedet. Ofte bliver ældre arbejdstagere ikke tilbudt nogen former for kompetenceudvikling. Det er nødvendigt, at der udvikles effektive måder, hvorved man kan bekæmpe aldersdiskrimination. Herunder bør der findes metoder til at ændre negative holdninger og adfærd overfor ældre arbejdstagere på arbejdspladserne, og i samfundet som helhed. Der kan imidlertid være objektive grunde til, at arbejdspladserne kun modvilligt ansætter ældre arbejdstagere, $\mathrm{fx}$ fordi anciennitetsbaserede lønsystemer har tendens til at gøre ældre arbejdstagere omkostningstunge. Der er behov for at se nærmere på arbejdspladsperspektivet og besvare følgende spørgsmål: hvad er de objektive grunde til, at arbejdspladserne har så stor modvilje mod at ansætte ældre arbejdstagere? Og hvordan opfylder man arbejdspladsernes behov?

- Bekæmpelse af stigmatisering. Hvis seniorpolitikken på arbejdsmarkedet og arbejdspladserne kun fokuserer på ældre arbejdstagere som værende "udsatte", og hvis de ældre arbejdstagere selektivt bliver berettiget til et bedre arbejdsmiljø og bedre arbejdsforhold end deres yngre kollegaer, opstår der en risiko for stigmatisering. Stigmatisering kan have alvorlige negative konsekvenser som for eksempel, at der opstår spændinger mellem aldersgrupperne, som resulterer i manglende social støtte og sammenhold samt manglende engagement i og tilfredshed med arbejdet etc. Der findes ikke meget viden om, hvorfor og hvornår stigmatisering opstår, og hvad de reelle konsekvenser er. Et vigtigt parameter herfor kunne være tilvejebringelse af mere viden om, hvordan man på arbejdspladserne sikrer en effektiv anvendelse af forskellene i kompetencer mellem yngre og ældre arbejdstagere, fx gennem mentorordninger, sammensætning af arbejdsteam etc. 


\section{Samantekt á íslensku}

Vinnuumhverfi starfsmanna er sjaldnast eina ástæðan fyrir pví að peir velja að fara fyrr á eftirlaun heldur hefur samspil fleiri pátta persónubundinna (s.s heilsa, fjármál o.fl.), í nær umhverfi (vinnustaður, fjölskylda og nánasta tengslanet), og og í skipulagi samfélagsins (vinnumarkaðslöggjöf og reglur) áhrif á hvort starfsmenn fara á eftirlaun eða halda áfram að vinna. Sú fræðilega nálgun sem Nilsson (2016) setur fram lýsir ferlinu á greinargóðan hátt. Tvenn megin viðhorf eru ráðandi að pessu leyti:

- Sýnin á hinn berskjaldaða eldri starfsmann_par sem stór hópur hefur takmarkaða getu, glímir við heilsufarsvanda og skortir hæfni, hópurinn hefur pörf á vernd og aðlögun til pess að eiga möguleika á sjálfbærri og lengri starfsævi.

- Sýnin á hinn úrræðagóða eldri starfsmann par sem hópur eldri starfsmanna er við góđa heilsu og býr að mikilli hæfni. Á vinnustaðnum eru slíkir starfsmenn verðmætir og pá sér í lagi pegar yfirgripsmikil reynsla peirra nýtist. Til pess að halda í pessa starfsmenn parf að efla starfsánægju á vinnustaðnum.

Í Danmörku, Íslandi, Noregi og Svípjóð er eftirlaunaaldur misjafn. Að einhverju leiti er pessi mismunur tengdur sögu vinnumarkaðarins í hverju landi fyrir sig, vinnumenningu og hefðum í kringum starfslok og gildandi lögum og reglum á vinnumarkaði. Danmörk sker sig úr pessum hópi hvað varðar snemmbær starfslok, en pað fyrirkomulag hefur nýst til pess að draga úr prýstingi á vinnumarkaði á tímum atvinnuleysis. Pví má segja að snemmbær starfslok séu par æskileg og félagslega sampykkt. Á hin bóginn hefur löng starfsævi tíðkast meðal hinna pjóðanna og unnið hefur verið gegn atvinnuleysi meðal allra aldurshópa á vinnumarkaði. Starfsöryggi er hærra meðal peirra pjóða en mun lægra í Danmörku par sem atvinnuleysi eldri starfsmanna mælist hærra. Brotthvarf eldri einstaklinga af vinnumarkaði vegna örorku hefur verið fátíðara í Danmörku og á Íslandi, en mun tíðara í Noregi og Svípjóð. Í Danmörku og á Íslandi hafa eldri starfsmenn sem glíma við heilsufarsberst ekki sömu möguleika á að færast af vinnumarkaði og á örorkubætur og purfa pví frekar að treysta á að fara fyrr á eftirlaun.

\section{Áhrif vinnuumhverfis á starfslok}

Ađeins hefur verið lagt mat á áhrif vinnuumhverfis á starfslok útfrá örorku og veikindum starfsmanna en ekki útfrá valfrjálsum starfslokum peirra. Matið er pví nátengt heilsufari og skortur er á pekkingu varđandi áhrif vinnuumhverfis á valfrjáls starfslok (t.d. ánægju í starfi og áhugahvöt). Hægt er að rekja stóran hluta ástæðna fyrir starfslokum vegna örorku í Danmörku til líkamlegs erfiðis i vinnuumhverfinu (21\% hjá körlum og 34\% hjá konum), auk pess sem tveir sálfélagslegir pættir (réttur til ákvörðunartöku og 
breytileiki) útskýrðu 10-15\% áhættunnar. Í Noregi er sömu sögu að segja par sem fimm sálfélagslegir og átta vinnuvistfræðilegir áhrifapættir útskýrðu $45 \%$ af ástæðunni fyrir starfslokum á örorkubótum. Að lokum má geta pess að $30 \%$ af langtíma veikindafjarvistum tengjast sálfélagslegum vinnuaðstæðum í Danmörku, en um 3154\% langtíma veikinda má rekja til vinnuumhverfis í Noregi.

\section{Vinnuumhverfipættir spá fyrir um starfslok}

Tengslin á milli ýmissa vinnuumhverfispátta á brotthvarf af vinnumarkað̌i hafa verið rannsökuð ítarlega á öllum norðurlöndunum og hafa niðurstöður peirra rannsókna verið nokkuð svipaðar. Við teljum pví óhætt að heimfæra niðurstöður frá einu Norðurlandanna til allra hinna. Við ályktum sem svo að eftirfarandi vinnuumhverfispættir segi til um snemmbært brotthvarf af vinnumarkaði: vinnuslys, titringur á líkama, líkamlegt álag (t.d. erfiðisvinna, pungar byrðar, að standa lengi við vinnu, stjórnun vinnu/sjálfræði/áhrif í vinnu, starfsánægja, magnbundnir pættir (t.d. vinnuhraði og tímapressa), forystustuðningur, ágreiningur á vinnustað, einelti/áreiti og aldurstengd mismunum. Að auki má geta pess að pó nokkurt efni er til um mögulega hæfnispróun í starfi pó svo pað efni sé ekki eins vel rökstutt. Að lokum má geta pess að takmarkaðar rannsóknir hafa verið framkvæmdar á Norðurlöndunum er snúa að efnanotkun, hávaða, vaktavinnu, vinnufélagastuðningi, skipulagsábyrgð og hræðslu við að stokka upp kerfið í kringum snemmbær starfslok. Meðal allra Norðurlandanna má finna sterk áhrif félagslegrar stöðu á snemmbær starfslok og tengsla við heilsufar og óviðunandi vinnuumhverfi. Áhrif breytinga á velferðarkerfin s.s. minnkandi aðgangur að öryrkjabótum hafa ekki verið rannsökuð og sama má segja um heilsutengda misskiptingu meðal kynjanna og meðal ákveðinna stétta.

\section{Samanburður vinnuumhverfis eldra fólks á Norðurlöndunum}

Kannanir á vinnuumhverfi og heilsu hafa verið framkvæmdar í Danmörku, Íslandi, Noregi og Svípjóð. Samanburður á milli landanna gefur bæði til kynna svipaðar niðurstöður en einnig ólíkar.

Eldri konur í verkamannastörfum í Danmörku virðast verða frekar fyrir áhrifum af einhæfum verkum við vinnu sína en karlkyns samlandar peirra. Áhrif einhæfrar vinnu eru aftur á móti svipuð gagnvart bæði konum og körlum í Noregi og Svípjóð. Í Noregi og Svípjóð er einnig minna um pað að konur verði fyrir líkamlega erfiðum verkefnum við vinnu, (einkun í Svípjóð), auk pess sem pær verða minna fyrir áhrifum af pungum byrðum (einkum í Noregi), og minna fyrir áhrifum af vinnuumhverfi par sem lyfta parf höndum upp fyrir axlir, en eldri karlkyns starfsmenn, pessu er öfugt farið í Danmörku. Heilt yfir má segja að líkamleg áhrif vinnuumhverfis á danskar konur sem sinna verkamannastörfum sé meiri en í Noregi og Svípjóð. Eldri starfsmenn í Danmörku og Svípjóð virðast verða svipað mikið fyrir áhrifum af óeðlilegum vinnustellingum og vinnu par sem lyfta parf höndum upp fyrir axlir. Báđir pessir pættir eru mun algengari en hjá 
eldri starfsmönnum í Noregi, en danskir og sænskir starfsmenn verða frekar fyrir óæskilegum áhrifum af titringi og hávaða en noskir eldri starfsmenn. Eldri starfsmenn í Danmörku verða frekar fyrir vinnuslysum en eldri starfsmenn í Noregi og á Íslandi (gögn vantar frá Svípjóð).

Einelti og áreiti er algengara hjá eldri starfsmönnum í Danmörku en í Svípjóð (miðlungs) og Noregi (mjög lágt). Norskir eldri starfsmenn fá meiri aðstoð og stuðning frá samverkamönnum sínum en eldri starfsmenn í Svípjóð og Danmörku. Á hinn bóginn hafa sænskir og danskir eldri starfsmenn meira um vinnuna að segja en norskir eldri starfsbræður peirra. Pegar pessar upplýsingar eru teknar saman má segja að líkamlegt og andlegt vinnuumhverfi eldri starfsmanna í Noregi sé mun betra en eldri starfsmanna i Svípjóð og Danmörku.

\section{Áhrif íhlutana á vinnustað til pess að halda í eldri starfsmenn}

Margir vinnustaðir á Norðurlöndunum gefa sig út fyrir að hafa stefnu sem gengur út á að halda í eldri starfsmenn en upplýsingar frá Danmörku sýna að minna en helmingur vinnustaða par í landi framkvæmir aðgerðir í pá veru. Í flestum tilfellum ganga slíkar stefnur út á að veita starfsmönnum tækifæri á að trappa sig niður í vinnu og hverfa smám saman af vinnumarkaði.

Helstu aðgerđir á pessu sviði snúast um sveigjanlegan vinnutíma, minni vinnutíma, fleiri frídaga/sumarfrísdaga og fríðindi. Sjaldan ganga aðgerð̌ir út á að minnka vinnuálag, bæta vinnuumhverfið eða starfshæfni. Ávinningurinn af stefnum og aðgerðum til pess að halda í eldri starfsmenn hefur aðeins verið kannaður í Noregi og bendir sú skoðun til pess að lítill árangur sé af peim. Pó skal taka fram að pótt erfitt geti verið að sýna fram á árangur, er ekki hægt að útiloka að hann sé til staðar pví flókið getur reynst að framkvæma vísindalega athuganir á íhlutunum af pessu tagi. Tilviksrannsóknir hafa verið framkvæmdar á öllum Norðurlöndunum sem sýna fram á góðan árangur af slíkum stefnum og aðgerðum.

Pó svo gott vinnuumhverfi sé mjög mikilvægt til pess að halda í eldra starfsfólk, er pekking á áhrifum íhlutanna á vinnuumhverfið sem ganga út á að halda i eldra starfsfólk takmörkuð. Núverandi pekkingargrunnur gefur til kynna tækifæri sem felast í pví að próa íhlutanir inn á vinnustöðum sem sameina bæði forvarnir gagnvart áhættupáttum í vinnuumhverfinu (t.d. áhættupáttum vinnuslysa, erfiðisvinnu/líkamlegs álags, ágreinings á vinnustað, eineltis/áreitis og mismunun vegna aldurs) og starfsánægju, par sem meiri áhersla er lögð á bætta stjórnun, starfspróun starfsmanna og viðurkenningu á málefninu af hendi stjórnenda. 


\section{Pörf á rannsóknum}

Með verkefninu hefur pörfin fyrir rannsóknir á eftirfarandi páttum verið greind:

- Hvernig hægt sé að öđlast jafnvægi á milli vinnu og einkalifs fyrir alla. Frekari rannsókna er pörf á áhrifum stefnumörkunar og íhlutanna sem miða að pví að auka sjálfbærni pess að hafa eldri starfsmenn í vinnu. Sér í lagi parf að afla pekkingar á pví hvernig hægt sé að koma til móts við eldri ómenntaðar konur á vinnumarkaði sem stunda vinnu par sem líkamlegt álag er mikið (t.d. í heilbrigðispjónustu, pjónustustörfum og prifum). Að auki parf að huga að innfluttu vinnuafli par sem menntunarstig er lágt og störf útheimta mikla líkamlega vinnu. Takmarkaðar upplýsingar eru til um hvernig hægt sé að koma í veg fyrir að pessi hópur detti af vinnumarkaði. Að lokum parf að efla vitneskju varðandi eldri starfsmenn sem glíma við langvarandi sjúkdóma en pessi hópur mun fara stækkandi i framtíðinni. Efla parf rannsóknir til pess að koma til móts við pessa hópa. Nauðsynlegt er að innleiða íhlutanir par sem forvarnir gagnvart áhættupáttum í vinnuumhverfinu og mismunun vegna aldurs leiða til aukinnar starfsánægju. Einnig parf nauðsynlega að efla aðgerðir sem byggja á sannreyndum aðferðum og draga saman pá pekkingu sem leitt getur af sér árangursríkar íhlutanir á vinnustöðum.

- Langtíma áhrif af lengri starfsævi. Sérstaklega parf að huga að eldri starfsmönnum með litla menntun sem búa við mikið álag í vinnu. Auka parf pekkingu á neikvæðum langtíma áhrifum og samverkandi páttum hættulegrar vinnu. Endurskoðun á stefnum og áætlunum á ekki aðeins að snúa að pví að halda eldra starfsfólki í vinnu heldur parf einnig að huga að heilsu starfsmanna og lífsgæðum, fyrir og eftir að starfsævi líkur. Mikið vantar uppá pekkingu á pví hvernig færslan á milli mismunandi bótakerfa hefur áhrif á starfsfólk (atvinnuleysisbætur, veikindaleyfi, sjúkratryggingar og örorkubætur). Kenningin er sú að lög á vinnumarkaði dragi úr hvata til pess að fara fyrr á eftirlaun - en pað mun ekki endilega auka hlutfall eldri starfsmanna á vinnumarkaði fyrir vikið. Pvert á móti getur álagið á ákveđna pætti bótakerfsins aukist par sem eldri starfsmenn með minni menntun og langtíma heilsufarsvandamál eiga erfiðara með að færast á milli starfa.

- Breytileiki starfslokaferlisins. Rannsóknir hafa til pessa horft á starfslok sem einstakan atburð sem tekur enda á ákveðnum tíma í stað pess að skoða ferlið í heild, en ákvörðunin um starfslok á sér yfirleitt töluverðan aðdraganda sem jafnvel spannar nokkur ár. Horfa parf á æviskeiðið í heild sinni, hvaða möguleika starfsmenn hafa til pess að vinna, hvaða viðhorf séu til staðar gagnvart pví og hvernig eldri starfsmenn sjá fyrir sér framtíðina sem eftirlaunapegar. Frekari pekkingar er pörf gagnvart heilsu, vellíðan og lífsgæðum starfsmanna sem eru að 
huga að starfslokum. Afla parf pekkingar á mögulegum ávinningi hlutastarfa og samspili peirra og pví að vera að hluta á eftirlaunum.

- Viðhorf vinnustaðarins._Minna en helmingur vinnustaða í Danmörku beitir virkum úrræðum til pess að halda eldri starfsmönnum í vinnu. Afla parf frekari pekkingar á pessu sviði og skoða hvers vegna ákveðnir vinnustaðir - en ekki allir - ákveða að ráða eða halda i eldri starfsmenn. Skoða parf hverjir pað eru sem verða fyrir íhlutun sem ætlað er að halda peim lengur í starfi. Einnig er skortur á pekkingu á pörf lítilla og meðalstórra fyrirtækja á pessu sviði og hvernig hægt sé að koma til móts við pær parfir, séu pær til staðar. Reynslusögur af árangursríkum aðgerðum par sem fyrirtæki réðu sérstaklega eldri starfsmenn vegna reynslu peirra eru til staðar (t.d. úr heildsölu og byggingariðnaði), en pessi dæmi hafa ekki verið tekin saman á skipulagðan hátt og pví er ekki vitað hve áræðanleg pau eru. Að lokum má geta pess að hagnýtt gildi sannreyndrar pekkingar fyrir vinnustaði er mjög takmarkað. Möguleikar vinnustaðarins til pess að meta stöðuna á vinnustaðnum og innleiða áætlanir og stefnur á pessu sviði kunna að vera takmarkaðir. Vera má að skortur á pessari pekkingu sé ein helsta hindrunin fyrir að lítil og meðalstór fyrirtæki haldi i eldra starfsfólk. pví er nauðsynlegt að taka saman pá pekkingu sem pó er til staðar og miðla henni til vinnustaða.

- Að berjast gegn aldursstengdri mismunun. Mismunun útfrá aldri er stađreynd á Norðurlöndunum. Helsta birtingarmynd hennar eru takmarkaðir möguleikar peirra sem eldri eru til pess að komast aftur inná vinnumarkað ef peir missa vinnuna. par með leiðir sú staða oft til pess að peir festast i ákveðnu starfi eða vinna störf sem eru umfram peirra getu á hverjum tíma. Pessi staða getur einnig leitt til snemmbærra starfsloka. próa parf árangursrikar leiðir til pess að berjast gegn aldurstengdri mismunum á vinnumarkaði, par með talið að breyta viðhorfum til eldri starfsmanna í samfélaginu og neikvæðni gagnvart peim. Pó skal pess getið að vinnustaðir hafa misjafnar ástæður fyrir pví að ráđa eldri starfsmenn í vinnu svosem vegna hærri launa sökum hærri lifaldurs. Að pví sögðu parf einnig að skoða frekar ástæður pessara viðhorfa og hvernig hægt sé að koma til móts við pau.

- Að berjast gegn fordæmingu. Ef viðhorf, stefnur og aðgerðir ganga útfrá pví að eldri starfsmenn séu á einhvern hátt viðkvæmari hópur á vinnumarkaði opnar pað möguleikann á pví að pað leiði til ákveđinnar fordæmingar hópsins, sér í lagi ef peir eiga kröfu á betra vinnuumhverfi en peir sem yngri eru. Fordæming eldri starfsmanna getur haft verulega neikvæð áhrif i för með sér og skapað núning á milli aldurshópa sem síðan leiðir af sér minni samheldni, stuðning og starfsánægju. Lítið er vitað um hvers vegna fordæming í pessu samhengi á sér stað og hvaða afleiðingar hún hefur. 



\section{Sammenfatning på norsk}

Arbeidsmiljøet er sjelden den eneste årsaken til tidligpensjonering. I de fleste tilfeller er det å pensjonere seg eller fortsette å arbeide resultat av et samspill mellom arbeidsmiljøet og en rekke andre faktorer. Disse faktorene er knyttet til ulike samfunnsnivåernivåer: på mikronivå (individuelle helse, kunnskap, arbeidskapasitet, økonomi, motivasjon, familie, etc.), på mesonivå (organisatoriske og ledelsesmessige forhold på arbeidsplassen) og på makronivå (arbeidsmarked og konjunkturer, pensjons- og trygdesystemet, arbeidslivslovgivning og -regulering). Dette blir tydelig illustrert i det teoretiske rammeverket til Nilsson (2016) (figur 3).

Figure 3: swAge-modellen - Teoretisk förklaringsmodell för Hållbart arbetsliv för alla åldrar

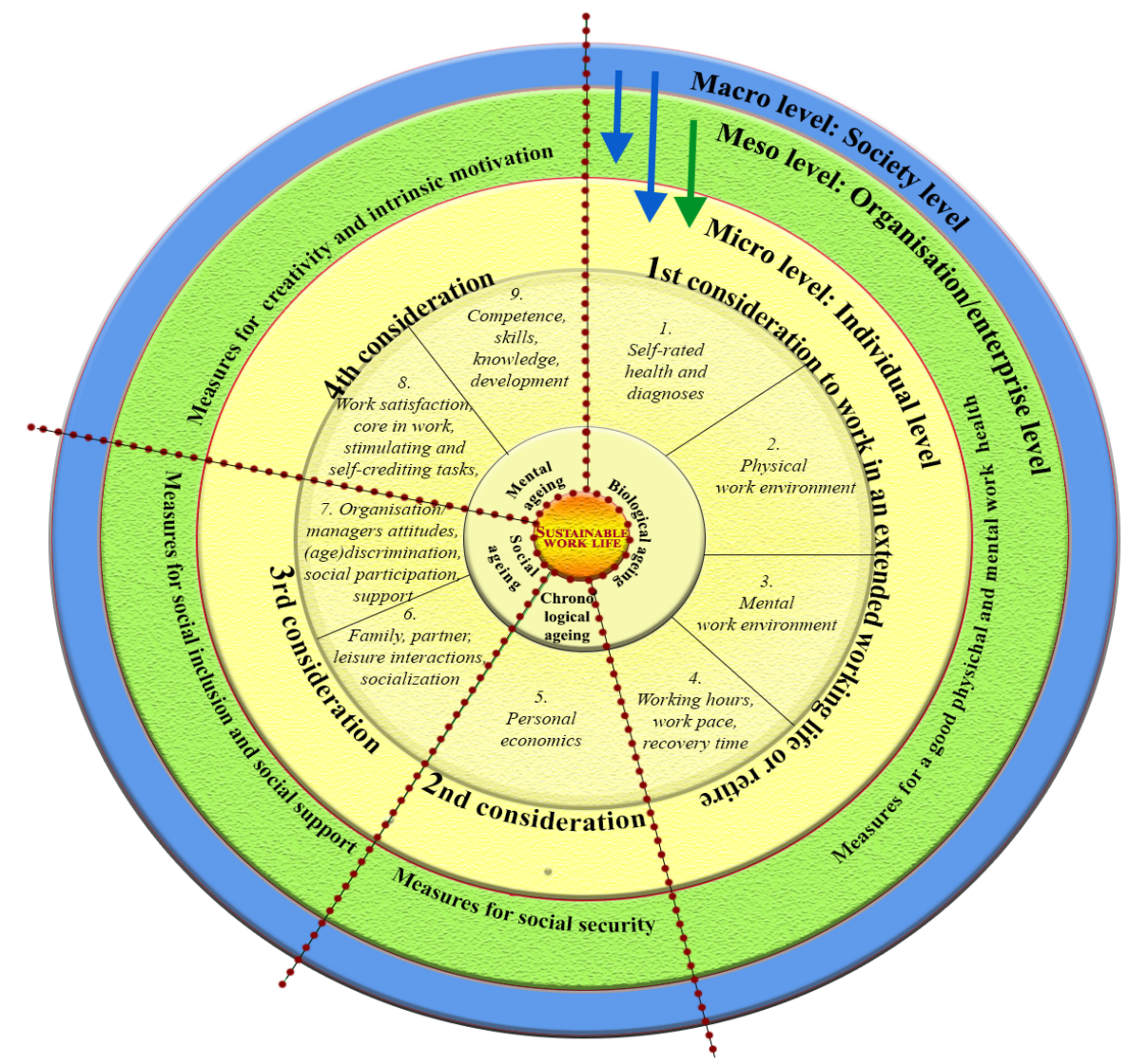

Source: Nilsson, K. 2016. 
Det finnes to sentrale perspektiver på seniorers arbeidsmarkedsdeltakelse:

- «Sårbare» eldre arbeidstakere-perspektivet (sliterperspektivet), som fokuserer på den store gruppen seniorer med helseproblemer, manglende kompetanse eller annen redusert arbeidsevne, og som har særlig behov for beskyttelse og tilrettelegging for å kunne jobbe til pensjonsalder og eventuelt lenger.

- Ressursperspektivet som primært fokuserer på de gruppene av eldre arbeidstakerne som har utmerket helse og god kompetanse. Arbeidsplassen anser gjerne disse seniorene som en verdifull og produktiv ressurs, spesielt hvis deres lange erfaring og gode ferdigheter kommer arbeidsplassen til gode. For å forlenge yrkeskarrieren for denne gruppen av arbeidstakere må arbeidsplassen fokusere på trivsel og muligheten for meningsfulle, utfordrende og stimulerende arbeidsoppgaver.

I de fire nordiske landene - Danmark, Island, Norge og Sverige - finnes det betydelige forskjeller i avgangsalder. Disse forskjellene er til dels historisk bestemt, men har også sammenheng med eksisterende forskjeller i «exit» kultur, pensjonssystemer, arbeidsmarkedsreguleringer og annen offentlig politikk. En stor forskjell er at Danmark har hatt en «early exit» (tidligpensjonerings-)kultur, der tidligpensjonering har blitt brukt til å redusere arbeidsstyrken i perioder med høy arbeidsledighet. Følgelig er tidligpensjonering allment og sosialt akseptert i Danmark. Derimot har de tre andre landene en sen «exit» kultur der arbeidsledighet har blitt bekjempet overfor alle aldersgrupper, også seniorene. Jobbsikkerhet er lav i Danmark, men høy i de andre landene. Derfor er også arbeidsledigheten blant eldre arbeidstakere høy i Danmark. Utgang via uførepensjon er sjelden i Danmark og Island, men hyppig i Norge og Sverige. Derfor kan eldre arbeidstakere med helseproblemer ikke ha mulighet til uførepensjon i Danmark og Island, og de kan i stedet bli tvunget til å ta frivillig førtidspensjon. Sverige innførte en trygdereform i 2008 som medførte begrensninger på sykepengerettighetene, og dette har medført en økning i tidlig pensjonsuttak også i Sverige, selv om flere også arbeider lenger.

I de fire nordiske landene - Danmark, Island, Norge og Sverige - finnes det betydelige forskjeller i avgangsalder og avgagsmønster, og disse forskjellene kan til dels tilskrives historiske og nåværende forskjeller i «exit» kultur, pensjonssystemer, arbeidsmarkedsreguleringer og annen politikk. En av grunnene til Danmarks lave avgangsalder er at de har hatt en «early exit» kultur (tidligpensjoneringskultur), hvor tidligpensjonering har vært et viktig verktøy for å redusere arbeidsstyrken i perioder med høy arbeidsledighet. Følgelig har det vært allment og sosialt akseptert i Danmark å gå av tidlig. I de tre andre landene derimot har det vært en «late exit» kultur (kultur for sen avgang) hvor man har vært opptatt av å redusere ledigheten i alle aldersgrupper, også blant seniorer. I tillegg har Danmark lav jobbsikkerhet, mens den er høy i de andre landene. Arbeidsledigheten blant eldre i Danmark er derfor høy. Avgang med uførepensjon er derimot sjelden i Danmark og på Island, men hyppig i Norge og Sverige. Eldre med helseproblemer i Danmark og Island har tilsynelatende ikke hatt de samme 
mulighetene til uførepensjonering, og derfor i større grad blitt tvunget til å ta ut frivillig førtidspensjon. Etter at Sverige innførte en trygdereform i 2008 med begrensninger i syke- og uførerettighetene har man også der fått en økning i tidlig pensjonsuttak. Det har skjedd parallelt med at flere eldre arbeider lenger.

\section{Effekten av arbeidsmiljø på pensjoneringstidspunkt}

Beregninger av omfanget av tidligpensjonering som skyldes selve arbeidsmiljøet er kun gjort for overgang til uførepensjon og lengre sykefravær, og i mindre grad for overgangen til frivillig førtidspensjon (AFP). I disse beregningene er det primært fokusert på skadelige risikofaktorer i arbeidsmiljøet. Vi mangler derfor kunnskap om den relative effekten av andre arbeidsrelaterte prediktorer for frivillig førtidspensjonering (for eksempel lav jobbtilfredshet og motivasjon). I Danmark kan en stor andel av uførepensjoneringen relateres til høye fysiske arbeidskrav (21\% for menn og $34 \%$ for kvinner), og to psykososiale arbeidsfaktorer (beslutningsmyndighet og variasjon) kan hver forklare $10-15 \%$ av risikoen for uførepensjonering. Lignende resultater finner man i Norge, der fem ulike psykososiale og åtte mekaniske (ergonomiske) risikofaktorer på arbeidsplassen kan forklare $45 \%$ av overgangen til uføretrygd. Videre kan $30 \%$ av langtidssykefraværet i Danmark kobles til psykososiale arbedsmiljøforhold, og i Norge kan mellom 31 og $54 \%$ av den sosiale ulikheten i langtidsfravær tilskrives arbeidsmiljøet.

\section{Arbeidsmiljøets betydning for pensjonering}

Sammenhengen mellom en rekke forskjellige arbeidsmiljøfaktorer og pensjoneringstidspunkt er grundig undersøkt i alle de nordiske landene, og sammenlignbare resultater er oppnådd på tvers av land. Vi mener derfor at funn fra ett land kan anses som gyldige også for de andre nordiske landene.

Det er godt dokumentert at følgende arbeidsmiljøfaktorer påvirker tidligpensjoneringen: arbeidsulykker, helkroppsvibrasjon, store fysiske arbeidskrav (f.eks. fysisk hardt arbeid, tunge løft, langvarig stående arbeid), kvantitative arbeidskrav (f.eks. høyt arbeidstempo og tidspress), manglende jobbkontroll/autonomi/innflytelse på arbeidet, manglende lederstøtte, arbeidskonflikter og mobbing/trakassering, manglende jobbtilfredshet og aldersdiskriminering. Utover dette finnes en viss dokumentasjon på at manglende mulighet til kompetanseutvikling er en prediktor. Det er imidlertid begrenset med forskning på sammenhengen mellom tidligavgang og henholdsvis kjemiske arbeidsmiljøfaktorer, sløy, skiftarbeid, manglende kollegastøtte, betydningen av jobbengasjement og frykt for omorganisering/nedbemanning.

I alle de nordiske landene er det en sterke sosial klassegradient i tidligpensjoneringen. Det er en sterk sammenheng mellom sosial klasse, helse og arbeidsmiljø. Effekten av innstramminger i velferdssystemet (som redusert tilgang til 
uføretrygd og sykepenger) for ulike sosioøkonomiske grupper (med ulik helse og ulikt arbeidsmiljø) trenger vi likevel mer kunnskap om, selv om det finnes noe forskning fra Sverige og Norge.

\section{Sammenligning av arbeidsmiljø for seniorer i de nordiske landene}

Nasjonale undersøkelser av arbeidsmiljø og helse gjennomføres både i Danmark, Island, Norge og i Sverige. Sammenligning av data fra de fire landene viser likheter, men også klare forskjeller.

Eldre danske kvinner i typiske arbeideryrker (ufaglærte) rapporterer i større grad enn menn eksponering for ensidig gjentakelsesarbeid, mens både menn og kvinner i denne typen jobber i Norge og Sverige rapporterer omtrent lik grad av eksponering. Videre rapporterer eldre kvinner i Norge og Sverige mindre eksponering for fysiske tungt arbeid (særlig lavt i Sverige), mindre eksponering for tunge løft (særlig lav i Norge) og mindre eksponering for arbeid med hendene løftet over skuldrene enn eldre menn i tilsvarende yrker, mens det motsatte er tilfellet i Danmark. Generelt ser det ut til at det fysiske arbeidsmiljøet for danske eldre ufaglærte kvinner er mer krevende enn for tilsvarende norske og svenske kvinner.

Danske og svenske eldre arbeidere rapporterer omtrent samme høye eksponering for arbeid i ubekvemme stillinger og arbeid med armene over skulderhøyde, og dette rapporteres i vesentlig større grad enn i Norge. Danske og svenske eldre menn er også mer utsatt for vibrasjoner og støy enn norske eldre menn.

Eldre danske arbeidstakere rapporterer også langt flere arbeidsskader enn eldre mannlige arbeidstakere i Norge og Island. I Sverige er arbeidsulykker og skader generelt høyere blant eldre arbeidstakere enn yngre. Det er også forskjell på arbeidskader mellom sektorer. Dette skyldes sannsynligvis at pensjonsalderen også varierer mellom sektorer. Andelen arbeidsskader med dødelig utfall er høyest blant bønder og skogsarbeidere i Sverige.

En langt større andel av eldre arbeidstakere i Danmark, enn i Sverige (mellomnivå) og Norge (veldig lav) utsettes for mobbing og trakassering. Norske eldre arbeidstakere synes å få mer støtte og hjelp fra nærmeste leder enn eldre arbeidstakere i Sverige og Danmark. På den annen side opplever svenske og danske eldre arbeidstakere oftere enn eldre norske arbeidstakere at de har kontroll over eget arbeid.

Samlet sett synes det fysiske og psykososiale arbeidsmiljøet for norske eldre arbeidstakere å være bedre enn for eldre arbeidstakere i Sverige og Danmark.

\section{Effekter av arbeidsplassintervensjoner for å holde på eldre arbeidstakeres}

I Danmark og Norge har under halvparten av arbeidsplassene tiltak for å beholde eldre arbeidstakere. Målet med de vanligste tiltakene er å gi mulighet til redusert arbeidstid eller en gradvis nedtrapping fra arbeidsmarkedet. Det som oftest tilbys er fleksibel 
arbeidstid, arbeidstidsreduksjon, ekstra ferie og fridager og bonuser/høyere lønn. I sjeldnere tilfeller inkluderer det ordninger som redusert arbeidsbelastning, forbedret ergonomi eller kompetanseutvikling. I Sverige hadr de fleste arbeidsplasser ingen politikk for fastholdelse av eldre ansatte. Bare $5 \%$ av kommunale ledere rapporterte at de har tiltak for å holde på eldre ansatte. Det dreide seg om helse- og treningsaktiviteter; kompetanseoverføring mellom generasjonene; redusert arbeidstid og spesifikke mentoriordninger.

Effekter av virksomhetenes arbeidsplasspolitikk og aktiviteter for å øke fastholdelse av eldre arbeidstakere har bare blitt systematisk evaluert i Norge. Generelt finner disse studiene at tiltakene har begrenset effekt på førtidspensjoneringen (AFPpensjonering) og sykefraværet. Imidlertid finner de at virksomhetsintervensjoner rettet mot arbeidstakere med helseproblemer og redusert arbeidskapasitet reduserer sannsynligheten for uførepensjonering, og at tilbud om ekstra fridag og bonuser kan utsette frivillig førtidspensjonering (AFP-pensjonering).

Manglende generell effekt av tiltak utelukker ikke at enkelte tiltak kan ha positive virkninger for noen grupper seniorer, i enkelte bedrifter og næringer. I alle de nordiske landene finnes det da også casestudier hvor arbeidsplasser mener de har klart å beholde eldre arbeidere på grunn av slike konkrete tiltak.

Selv om et godt arbeidsmiljø kan være av avgjørende betydning for fastholdelse av eldre arbeidstakere, er det mindre kunnskap om hvilken effekt arbeidsmiljøtiltak har på pensjoneringsadferden. Eksisterende kunnskap viser imidlertid at det er et stort potensial for å utvikle arbeidsplassintervensjoner som kombinerer forebygging av risikofaktorer i arbeidsmiljøet (f.eks. risiko for ulykker, anstrengende eller krevende arbeid, utilstrekkelig tid til restitusjon mellom arbeidsskift, konflikter, mobbing/trakassering og aldersdiskriminering) med en økning av jobbtilfredshet gjennom økt kontroll / innflytelse, gode utviklingsmuligheter og anerkjennelse fra ledelsen.

\section{Forskningsbehov}

Projektet har identifisert forskningsbehov på følgende overordnede områder:

- Oppnåelse av et bærekraftig arbeidsliv for alle aldere. Det er behov for mer forskning på hva som er en effektiv arbeidsplasspolitikk og effektive tiltak for å oppnå en bærekraftig fastholdelse av eldre arbeidstakere. Spesielt er det behov for kunnskap om eldre, lavt utdannede kvinnelige arbeidstakere som fastholdes $i$ jobber med fysisk høye krav (for eksempel innen helse- og omsorgssektoren, service og rengjøring). I tillegg har innvandrere ofte mer fysisk krevende manuelt arbeid enn man kunne forvente utifra utdanningsnivå, og kunnskap om hvordan man hindrer tidligavgang fra arbeidsmarkedet for eldre innvandrere er sparsom. Andelen eldre arbeidstakere med kroniske sykdommer forventes å øke i fremtiden. Det trengs derfor også mer forskning om hvordan arbeidet kan tilpasses for å ivareta denne gruppen. Det er også behov for nye arbeidsplassintervensjoner som kombinerer forebygging av risikofaktorer $\mathrm{i}$ 
arbeidsmiljøet og forbygging av aldersdiskriminering med tiltak for å øke ansattes jobbtilfredshet. I tillegg er det et presserende behov for mer "fra forskning til praksis"-kunnskap, om hvordan effektive tiltak kan formidles til virksomhetene.

- Langsiktige konsekvenser av et lengre arbeidsliv. Spesielt for lavt utdannede eldre arbeidstakere med belastende arbeidsoppgaver, er det behov for mer kunnskap om potensielle negative konsekvenser av en lengre og kumulativ eksponering. Evaluering av seniorpolitiske tiltak bør derfor ikke bare fokusere på arbeidsfastholdelse (dvs. forventet og faktisk pensjonsalder), men også på konsekvensene for arbeidstakernes helse og trivsel av et forlenget arbeidsliv (både før og etter avgang fra arbeidslivet). I denne sammenheng mangler det kunnskap om effekter av gjentatte overganger mellom ulike sosiale ytelsesordninger (arbeidsledighet, sykefravær og andre trygdeordninger) før endelig avgang. I teorien fører innstramninger i pensjonssystemet, som f.eks. begrensninger i muligheten til førtidspensjonering, ikke nødvendigvis til at flere eldre blir værende på arbeidsmarkedet. Alternativt kan det bli en økning i uttak av andre sosiale ytelsesordninger, særlig blant seniorer med lav arbeidsmarkedsmobilitet grunnet av manglende utdanning og/eller kroniske helseplager.

- Den dynamiske pensjoneringsprosess. Hittil har de fleste studier sett på pensjonering som en enkelt, avsluttet begivenhet, uten å ta i betraktning at beslutningen om å trekke seg tilbake, pensjoneringsprosessen, kan strekke seg over flere år. Det er derfor behov for å anlegge et lengre (livsløp) perspektiv på arbeidsevne og på holdninger til arbeid, og se hvordan disse endres over tid, og hvordan eldre arbeidstakere gradvis tilpasser seg det fremtidige livet som pensjonister. I tillegg er det behov for mer kunnskap om hvordan helse, trivsel, livskvalitet og holdninger endres i løpet av pensjoneringsprosessen. Det er også behov for mer kunnskap om mulige positive effekter av selvvalgt deltidsarbeid $i$ kombinasjon med delvis pensjonering.

- Arbeidsplassperspektivet. Under halvparten av arbeidsplassene (i Danmark og Norge) har tiltak for å holde på eldre arbeidstakere. Og selv om kunnskapen om motivasjon for og effekter av tiltak eksisterer i Norge, er det behov for mer kunnskap i Danmark, Island og Sverige om virksomhetenes motiver og perspektiver: Hvorfor bestemmer noen arbeidsplasser - men ikke alle - seg for å rekruttere og/eller beholde eldre arbeidstakere? Hvilke grupper eldre arbeidstakere tilbys de forskjellige typene tiltak og hvorfor? Det mangler særlig kunnskap om hva som er behovene til små og mellomstore bedrifter (SMB), og hvordan disse behovene kan imøteskommes. Det finnes eksempler fra bl.a. varehandel og byggebransjen der virksomhetene har rekruttert seniorer for å nyttegjøre seg deres erfaring, men disse case-historiene er ikke systematisk beskrevet. Foreliggende kunnskap om effektene av denne type seniorpolitikk er derfor sparsom. Endelig er den praktiske bruken av forskningsbasert kunnskap på arbeidsplassen svært begrenset. Det kan også godt tenkes at mange arbeidsplasser ikke har de nødvendige ressursene til å innhente et tilstrekkelig 
kunnskapsgrunnlag for sin seniorpolitikk, og mangel på kunnskap kan i seg selv være en viktig barriere for et bærekraftig utvidet arbeidsliv, særlig på små og mellomstore bedrifter. De er derfor behov for mer effektiv kunnskapsformidling fra forskning til praksis på virksomhetsnivå.

- Bekjempelse av aldersdiskriminering. I alle de nordiske landene forekommer aldersdiskriminering. Den vanligste effekten av aldersdiskriminering er at eldre arbeidstakere har begrensede muligheter til å få ny jobb om de blir arbeidsledige, og blir sittende fast i en jobb hvor kravene overstiger arbeidskapasiteten, eller blir tvunget til å ta ut førtidspensjon. En annen side ved aldersdiskriminering er at seniorer i mindre grad tilbys kompetanseutvikling. Det er derfor behov for å utvikle effektive virkemidler for å bekjempe aldersdiskriminering, herunder metoder for å endre negative holdninger og afderd overfor eldre arbeidstakere på arbeidsplassen, så vel som i samfunnet for øvrig. Virksomhetene kan imidlertid ha objektive grunner for ikke å ville ansette eldre arbeidstakere, f.eks. ansiennitetsbaserte lønnsystemer. Det er drfor behov for å se nærmere på arbeidsplassperspektivet, og å svare på spørsmålene: Hva er de objektive grunnene til at arbeidsplasser har så stor motvilje mot å ansette eldre arbeidstakere? Og hvordan kan man møte arbeidsplassenes behov?

- Bekjempelse av aldersstigmatisering. Om seniorpolitikk i arbeidsmarkedet og på arbeidsplassene kun fokuserer på eldre arbeidstakere som potensielt sårbare, og hvis eldre arbeidstakere selektivt har rett til et bedre arbeidsmiljø og en bedre arbeidssituasjon enn sine yngre kolleger, er det risiko for stigmatisering. Stigmatisering kan ha alvorlige negative konsekvenser, og føre til spenninger mellom aldersgrupper, som igjen kan resultere i redusert sosial støtte og kollegafellesskap, samt redusert jobbengasjement og jobbtilfredshet, etc. Det er lite kunnskap om hvorfor og når stigmatisering oppstår, og hva de faktiske konsekvensene er. Det kan derfor være viktig å tilveiebringe mer kunnskap om hvordan eldre og yngres forskjellige kompetanse kan utnyttes på en bedre og mer effektiv måte, for eksempel gjennom mentorskap, sammensetning av arbeidsgrupper, etc. 



\section{Sammanfattning på Svenska}

Arbetsmiljön är sällan den enda orsaken till tidig ålderspension. I de flesta fall interagerar arbetsmiljön med en mängd andra faktorer för att gå i pension eller fortsätta arbeta. Dessa faktorer finns på olika nivåer i samhället, dvs.: mikronivå (individens hälsa, arbetsmiljö, arbetstakt, ekonomi, arbetsmotivation, kunskap, familj, etc.), på meso nivå (organisatoriska och chefers åtgärder på arbetsplatsen) och på makronivå (socialförsäkringssystemet, arbetsmarknadslagstiftning och reglering). Detta illustreras tydligt genom den teoretiska ram som Nilsson föreslog (2016) (figur 4).

Figure 4: swAge-modellen - Teoretisk förklaringsmodell för Hållbart arbetsliv för alla åldrar

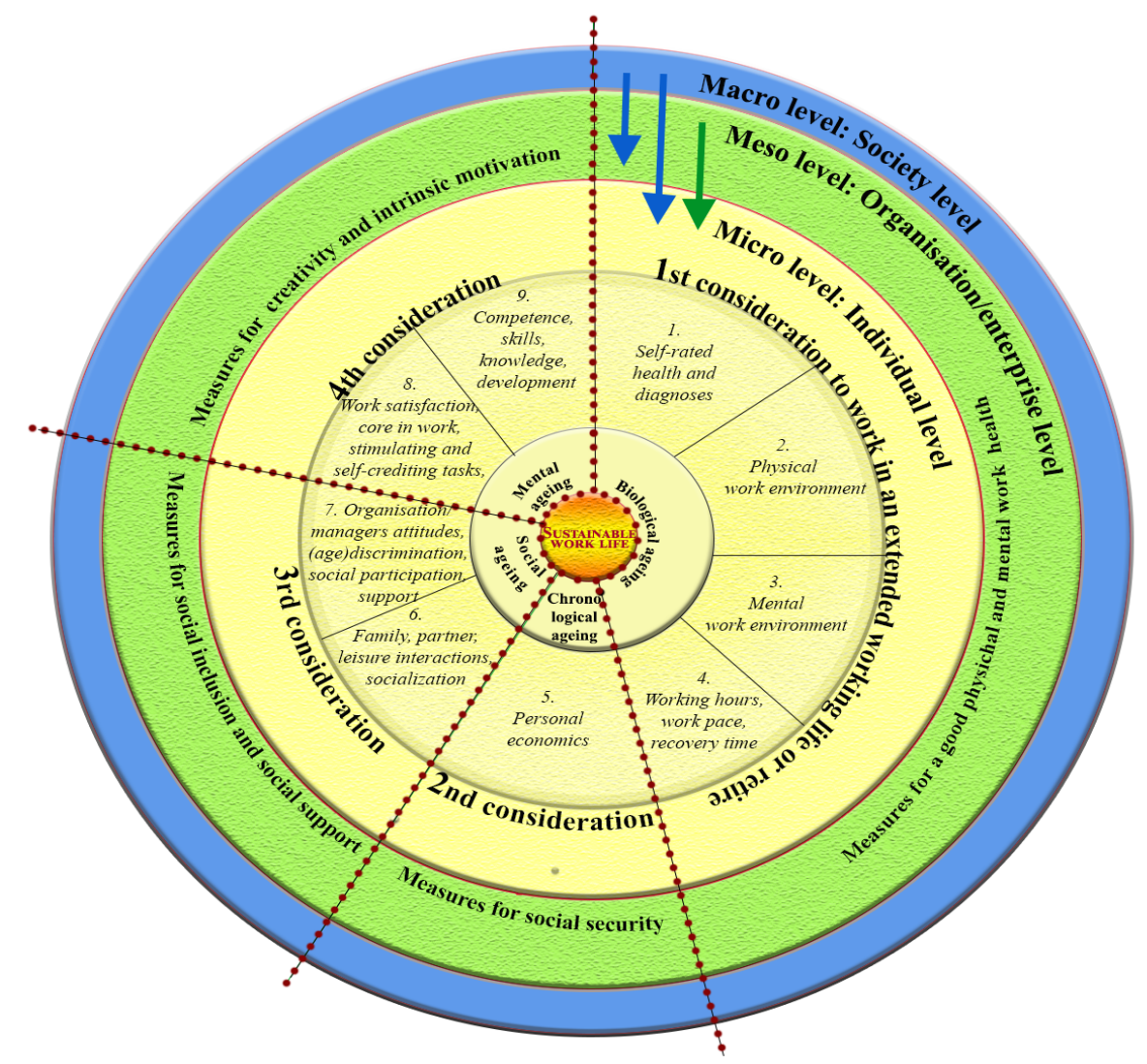

Source: Nilsson, K. 2016. 
På arbetsmarknadens finns det framförallt två perspektiv angående värnande av äldre arbetstagare:

- Perspektivet om den "sårbare" äldre arbetstagaren. Detta perspektiv fokuserar på gruppen äldre arbetstagare som om de har begränsad resurser på grund av degenerering, hälsoproblem och bristande kompetens. De äldre ses utifrån detta perspektiv som en grupp med särskilda behov och behov av skydd och arbetsanpassning om de ska klara av sitt arbete på ett hållbart sätt. För att förlänga arbetslivet för denna grupp arbetare behöver arbetsplatsen fokusera på att förbättra arbetsmiljön och återhämtningstiden och anpassa uppgifterna så att fler kan och vill arbeta vidare.

- Perspektivet om den resursfulla äldre arbetstagaren. Detta perspektiv fokuserar på gruppen av äldre arbetstagare som har en utmärkt hälsa och många kompetenser. På arbetsplatserna anses dessa äldre vara en värdefull och produktiv resurs. Särskilt om deras höga erfarenhetenskompetens kan utnyttjas. För att förlänga arbetslivet för denna grupp arbetare behöver arbetsplatsen fokusera på att förbättra arbetsnöjdheten och möjligheten till meningsfulla, utvecklande och stimulerande arbetsuppgifter.

I de fyra nordiska länderna - Danmark, Island, Norge och Sverige - finns betydande skillnader i pensionsålder. Dessa skillnader kan till viss del bero på historiska såväl som nuvarande skillnader $\mathrm{i}$ attityd, kultur, pensionssystem, arbetsmarknadsregler samt $\mathrm{i}$ politiken. En stor skillnad är att Danmark har haft en tidig "exit" kultur, där förtidspension har använts för att minska arbetskraften i perioder med hög arbetslöshet. Följaktligen är förtidspensionering allmänt och socialt accepterad i Danmark. Däremot har de tre andra länderna en sen "exit" kultur, där arbetslöshet har bekämpats i alla åldersgrupper. Arbetssäkerheten är låg i Danmark, men hög i övriga länder. Därför är arbetslösheten för äldre arbetstagare hög i Danmark. Avgång via sjukoch invalidpension (dvs. sjukersättning i Sverige) är sällsynt i Danmark och Island, men vanligare i Norge och Sverige. Därför kan äldre arbetstagare med hälsoproblem i Danmark och Island inte ha möjlighet till invalid/sjukpension, och de bli istället tvungna att ta frivillig förtidspension. Dock har den begränsning av möjligheten till sjukpenning och sjukersättning som infördes vid socialförsäkringsreformen 2008 i Sverige medfört att andelen med tidig ålderspension även har ökat där, även om flera även arbetar till en högre ålder.

\section{Inverkan av arbetsmiljö vid pensionering}

Beräkning av andelen som går i pension på grund av arbetsmiljön har endast gjorts för övergång till sjukfrånvaro och invalidpension/sjukpension/sjukersättning, men inte för övergång till frivillig förtidaålderspension. Statistiska beräkningarna av andelen som går i pension är främst hälsorelaterade, och kunskapen är bristfällig angående den relativa effekten av andra arbetsrelaterade prediktorer för frivillig förtidspensionering 
(t.ex. effekten av bristande arbetsnöjdhet och motivation). I Danmark kan en stor del av förtidspensionen härledas till fysiskt krävande arbetsförhållanden (21 \% för män och 34 \% för kvinnor) men två psykosocialt relaterade faktorer (krav och kontroll) kan även förklara 10-15\% av risken för den danska invaliditetspensionen. Liknande resultat visas i Norge där en studie visade att fem psykosociala och åtta ergonomiska riskfaktorer i arbetet kunde förklara $45 \%$ av förtids/sjukpensionen. Vidare beräknas ca $30 \%$ av långtidssjukfrånvaron i Danmark beror på den psykosociala arbetsmiljön, och i Norge beräknas ca 31-54 \% bero på arbetsmiljön.

\section{Arbetsmiljöns betydelse för pensionering}

Relationen mellan flertalet olika arbetsmiljöfaktorer och utträde från arbetsmarknaden har studerats i detalj i alla nordiska länder, och de jämförbara resultaten har varit mycket likartade. Vi föreslår därför att evidens från ett land kan anses vara giltiga även i de övriga nordiska länderna.

Följande faktorer i arbetsmiljön är väl dokumenterade som orsak till tidigt utträde ur arbetsmarknaden: sjukdom och ohälsa; arbetsolyckor och fysiska arbetsmiljöbelastningar (t.ex. kroppsvibrationer, ansträngande arbete, tunga lyft, långvarigt statiska arbetsställningar, monotona och repetitiva rörelser); mental arbetsmiljö, (t.ex. stress, krav och kontroll, mobbning / trakasserier, våld); arbetstid och arbetstakt (t.ex. arbetshastighet och tidspress); lön och ekonomi; attityder från chefer och andra (från arbetskamrater, klienter, patienter), social inklusion, delaktighet, ledarskapsstöd och åldersdiskriminering (t.ex. autonomi / inflytande på jobbet, arbetsstyrning, konflikter på jobbet); arbetsnöjdhet, arbetsuppgiftens innehåll och arbetsmotivation; samt kompetens och behovet av möjligheter till kompetensutveckling för ett förlängt arbetsliv (se figur 1). Slutligen har begränsad nordisk forskning även gjorts om effekterna av kemiska arbetsfaktorer, buller, skiftarbete, kollegors stöd, gemenskap, chefsstöd, organisatoriskt engagemang och rädsla för omorganisation för tidigt utträde ur arbetskraften.

I alla nordiska länder finns en stark social klassgradient vid tidig arbetskrafts utträde till pension. Social klass, hälsa och arbetsmiljö är nära knutna till varandra. Effekterna av flera nyligen införda restriktioner i välfärdssystemen, ojämlikhet mellan män och kvinnor och mellan socioekonomiska grupper samt skillnad i tillgången till invalidpension/sjukpension/ sjukersättning i de nordiska länderna behöver studeras mer i detalj, även om det till viss del har studerats i exempelvis Sverige.

\section{Jämförelse av arbetsmiljön hos äldre arbetstagare i Norden}

Nationella undersökningar om arbetsmiljö och hälsa utförs i Danmark, Island, Norge och Sverige. Jämförelse av data från de fyra länderna visar likheter, men också tydliga skillnader. Aktivt Systematiskt arbetsmiljöarbete utifrån arbetsmiljölagstiftningen $i$ Sverige har visat sig ge en statistiskt signifikant ökning av andelen äldre medarbetare 
som kan arbeta till 65 år eller längre. Medan tillgången till Företagshälsovård inte uppvisat någon effekt på att fler kan arbeta till en högre ålder.

Äldre danska kvinnorna i traditionella arbetaryrken rapporterar i högre grad än män exponering för monotona rörelser $\mathrm{i}$ arbetet, medan kvinnor och män i Norge och Sverige rapporterar ungefär samma exponering för monotona rörelser i arbetet. Vidare tenderar äldre kvinnor i Norge och Sverige att rapportera mindre exponering för fysiskt ansträngande arbete (särskilt låg i Sverige), mindre exponering för tunga lyft (särskilt låg i Norge) och mindre exponering för arbete med händerna lyfta över axeln än äldre män, medan motsatsen rapporterats i Danmark. I allmänhet rapporterar äldre danska kvinnor i arbetaryrken mer krävande fysiska arbetsmiljön, än de norska och svenska äldre kvinnorna. Danska och svenska äldre arbetstagare i klassiska arbetaryrken rapporterar ungefär samma höga exponering för arbete i besvärliga kroppsställningar och av att arbeta med händerna lyfta över axelhöjd. Exponeringen av dessa båda fysiskt problematiska arbetskrav överstiger betydligt den exponeringen som de norska äldre arbetstagarna tycks utsättas för. Danska och svenska äldre män är också mer utsatta för vibrationer och höga ljud än norska äldre män.

De danska äldre arbetstagarna har långt fler arbetsolyckor än äldre arbetstagare $\mathrm{i}$ Norge och Island. I Sverige är arbetsskadorna bland äldre generellt högre än för övriga åldersgrupper. Dock även höga för yngre medarbetare. Det är även skillnad beträffande äldres arbetsskador mellan olika branscher. Detta beror troligen på att pensionsåldern varierar mellan olika branscher och yrken. Andelen arbetsskador med dödlig utgång är högst bland äldre lantbrukare och skogsarbetare.

Mobbing, trakasserier och åldersdiskriminering upplevs av en betydligt större andel äldre arbetstagare i Danmark än i Sverige. Detta är dock än lägre i Norge. Norska äldre arbetstagare upplever mer stöd och hjälp från sin närmaste chef och arbetsledare, än vad äldre arbetstagare i Sverige och Danmark rapporterar. Å andra sidan upplever svenska och danska äldre arbetare oftare högre egenkontroll över hur arbetet ska utföras än vad de norska äldre arbetstagarna rapporterar.

Sammantaget verkar den fysiska och psykosociala arbetsmiljön hos norska äldre arbetare i allmänhet vara bättre än hos äldre arbetstagare i Sverige och Danmark.

\section{Effekter av arbetsplatsinterventioner för äldre arbetstagares möjlighet till ett längre arbetsliv}

I Danmark och Norge har mindre än hälften av arbetsplatserna vidtagit praktiska åtgärder för att främja möjligheten för äldre arbetstagare att fortsätta arbeta. Arbetsplatsernas policy och åtgärder syftar oftast till att ge möjlighet att gå ner i arbetstid och gradvis utfasning från arbetsmarknaden, och består huvudsakligen av flexibel arbetstid, minskad arbetstid, fler på semesterdagar och bonusar. Aktiviteterna innefattar sällan minskad arbetsbelastning, förbättrad ergonomi eller kompetensutveckling. Effekter av företagens och organisationernas policy och aktiviteter för äldre arbetstagare har bara utvärderats systematiskt i Norge. I allmänhet visar utvärderingen att interventioner från norska företag har begränsad effekt på 
förtidspension och sjukfrånvaro. De företagsåtgärder riktade till arbetstagare med hälsoproblem och minskad arbetskapacitet minskar dock sannolikheten för sjukpensionering, samt att erbjudande om extra lön och bonus skjuter upp tidig ålderspension. Trots bristen på generella bevis utesluts inte att vissa positiva effekter kan ha uppstått för någon grupp arbetare och i vissa företag och industrier.

I Sverige har de flesta arbetsplatser inte någon policy för äldre anställda. Endast 5\% av cheferna i kommunala verksamheter i Sverige rapporterar att de i sina verksamheter hade policy och åtgärder för att medarbetare skulle kunna och vilja arbeta till en högre ålder. De vidtagna åtgärderna beskrevs vara: hälso- och finess aktiviteter; överföringsprojekt av färdigheter och kunskaps mellan generationer; arbetstidsåtgärder och möjlighet för minskning av arbetstiden för äldre anställda; samt specifika mentorskap- / handledningsprojekt.

I samtliga nordiska länder finns det arbetsplatser som framgångsrikt har behållit äldre arbetstagare på grund av specifika insatser. Dock så är den befintliga kunskapen generellt bristfällig angående specifika åtgärder och insatser och effekterna på pensionsbeteenden. Detta trots att en bra arbetsmiljö kan vara av avgörande betydelse för att äldre arbetstagare ska kunna och vilja arbeta kvar några år till. Den nuvarande kunskapen indikerar dock en stor potential för att utveckla arbetsplatsinterventioner som kombinerar förebyggande av riskfaktorer i arbetsmiljö (t.ex. riskfaktorer för olyckor, ansträngande arbete / fysiska arbetsmiljöproblem, otillräcklig återhämtning mellan arbetsskift, kvantitativa arbetskrav, arbetsskador och mobbning / trakasserier och åldersdiskriminering) med ökad arbetsnöjdhet genom ökad kontroll / inflytande, meningsfulla och stimulerande arbetsuppgifter, kunskaps och utvecklingsmöjligheter samt stöd och erkännande från ledningen och chefer.

\section{Forskningsbehov}

Projektet har identifierat forskningsbehov kopplade till följande teman:

- Hur kan vi uppnå hållbart arbetsliv för alla åldrar:

- Mer forskning behövs om effektiv arbetsplatspolicy och insatser för att göra arbetslivet mer hållbar för äldre arbetstagare. I synnerhet behövs kunskap för äldre lågutbildade kvinnliga arbetare som fastnat i jobb med fysiska höga krav (t ex vård, service och städning).

- Andelen äldre arbetstagare med kroniska sjukdomar förväntas öka i framtiden, vilket kan minska möjligheten för arbetskraftsdeltagande. Forskning behövs för att anpassa arbetet till dessa äldre arbetstagare.

- Aktivt Systematiskt arbetsmiljöarbete har visat sig öka möjligheten för äldre att arbeta till en högre ålder. Medan tillgången till Företagshälsovård inte uppvisat någon effekt för att fler äldre kan till en högre ålder i Sverige. Det är viktigt att stödsystem som arbetsmiljöinspektörer och företagshälsovårdspersonal samt HR-personal utbildas i hur arbetslivet kan 
göras hållbart. I Sverige utbildas alla Arbetsmiljöverkets

arbetsmiljöinspektörer i swAge-modellen (se figur 1) för att stödja chefer, HR, företag och organisationer i deras arbete med att skapa hållbara arbetsplatser för alla åldrar.

- Det behövs nya arbetsplatsinterventioner som kombinerar förebyggande av arbetsmiljöfaktorer och åldersdiskriminering med ökad arbetstillfredsställelse hos de anställda.

- Det finns ett brådskande behov av mer kunskap om hur man implementerar forskning i arbetslivet, samt mer kunskap om hur man sprider lärdom om effektiva insatser på arbetsplatserna, dvs. "från forskning till praktiken"

- Den nuvarande kunskapen om hur man förhindrar tidigt utträde från arbetsmarknaden bland äldre migranter är bristfällig. Migranter tenderar i högre grad än infödda att erhålla mer fysiskt krävande manuellt arbete än vad som kan förväntas utifrån utbildningsnivå. Kan detta vara en orsak till att migranter ofta lämnar arbetslivet tidigare än infödda?

- Uppnå balans mellan arbete och privatliv för sandwich generationen, dvs. äldre arbetstagare med åldrande föräldrar att ta hand om samtidigt som deras barn och barnbarn behöver stöd och hjälp.

- Långsiktiga konsekvenser av ett längre arbetsliv och senareläggande av ålderspensionen:

- Det behövs mer kunskap om eventuella negativa följder av längre och kumulativ exponering för yrkesrisker. Särskilt för korttidsutbildade äldre arbetstagare med hög grad av belastande arbetsexponeringar.

- Utvärdering av arbetsplatspolicy och åtgärder bör fokusera på arbetstagarnas hälsa och välbefinnande under det längre arbetslivet och efter pensionering, och inte bara på antal år i arbete (dvs. inte enbart på individers förväntad och faktiska pensionsålder).

- Det finns en viktig brist avseende kunskap om effekter av övervältring mellan olika sociala förmånssystem (arbetslöshet - sjukfrånvaro - socialtjänst invalidpension/sjukpension/sjukersättning), samt vilken effekt skillnaden mellan de nordiska ländernas sociala förmånssystem orsakar. I teorin kan pensionssystemets regler öka andelen äldre människor på arbetsmark genom att begränsa möjligheten till tidigt utträde ur arbetskraften och pension. Detta sker dock inte nödvändigtvis i praktiken. Alternativt kan istället en överföring ske mellan olika sociala förmånssystem, särskilt för äldre personer med låg arbetsmarknadsmobilitet på grund av brist på utbildning och / eller med kroniska hälsoproblem.

- Pensioneringens dynamic:

- Ett längre livslängdsperspektiv behövs på arbetsförmåga och arbetssätt, hur dessa förändras över tiden och hur äldre arbetstagare gradvis anpassar sig till det framtida livet som pensionärer. Beslutet att gå i pension och övergången från arbetsliv till heltidspensionär tar oftast flera år. 
- Det krävs mer kunskap om hur hälsa, välbefinnande och livskvalitet förändras under pensioneringsprocessen.

- Det behövs också mer kunskap om eventuella positiva effekter av frivillig deltidsanställning i kombination med partiell pensionering.

- Arbetsplatsperspektivet:

- Det är allt för få arbetsplatser som vidtagit konkreta åtgärder för att främja möjligheten för äldre arbetstagare att arbeta till en högre ålder.

- Potentiellt viktiga fallhistorier finns angående arbetsplatser (t.ex. offentlig verksamhet, byggföretag, förpackningsindustri, tryckeri, kunskaps- och konsultföretag, fastighetsförvaltningsföretag, försäljnings- och byggmarknader) i Sverige och Norge som aktivt behållit eller rekryterat äldre anställda för att utnyttja deras erfarenhet, men alla fallen har inte systematiskt beskrivits mer än i Norge. Den nuvarande kunskapen om effekterna av denna typ av seniorpolitik är inte tillräcklig.

- Norge och Sverige har kunskap om arbetsplatsers motiv och perspektiv till varför arbetsplatser vill och kan behålla äldre medarbetare, men mer kunskap behövs även i Danmark och Island: Varför bestämmer vissa arbetsplatser att behålla äldre arbetstagare, medan andra inte vill eller kan det? Vilka typer av äldre arbetstagare erbjuds åtgärder och varför?

- Mer kunskap behövs angående de små och medelstora företagens (SME) behov av äldre medarbetare, och hur dessa behov kan tillgodoses. Viss kunskap finns i Sverige och Norge.

- Bristande kunskap på arbetsplatserna kan vara ett viktigt hinder för ett hållbart utökat arbetsliv. Den praktiska användningen av forskningsbaserad kunskap på arbetsplatserna är mycket begränsad. Det kan vara så att många arbetsplatser inte har tillräckliga resurser för att ta dela av ny kunskap, samt för att informera och stödja sina chefer och medarbetare i arbetsplatspolitik och praktiska aktiviteter. Därför finns det också ett starkt behov av effektivare kunskapsspridning från forskning till praktik på arbetsplatser.

- Bekämpa åldersdiskriminering:

- I alla nordiska länder förekommer åldersdiskriminering.

- Den mest framträdande effekten av åldersdiskriminering är att äldre arbetstagare har mycket begränsade möjligheter att få ett nytt jobb om de blir arbetslösa och därför ofta fastnar i ett jobb där kraven överstiger deras arbetsförmåga eller tvingas att lämna arbetslivet.

- Äldre arbetstagare erbjuds ofta inte kompetensutveckling.

- Effektiva sätt att bekämpa åldersdiskriminering måste utvecklas, bland annat hur man förändrar kulturella uppfattningar av äldre arbetstagare på samhällsnivå och negativa attityder och beteenden på arbetsplatserna.

- Det finns behov av att titta närmare på arbetsplatsperspektivet och att svara på frågorna: Vilka är de objektiva anledningarna till att arbetsplatser är 
ovilliga att anställa äldre arbetstagare? Och hur kan arbetsplatsernas behov tillgodoses? Arbetsplatserna kan ha objektiva skäl för att vara ovilliga att anställa äldre arbetstagare, t.ex. på grund av lönesystemet.

- Bekämpa stigmatisering:

- Det finns risker för stigmatisering om arbetsmarknadspolitiken och arbetsplatspolicy fokuserar äldre arbetstagare som potentiellt "sårbara" och ger alla äldre arbetstagare rätt till bättre arbetsmiljö och bättre arbetsförhållanden än sina yngre kollegor. Stigmatisering kan ha allvarliga negativa konsekvenser, det vill säga spänningar mellan åldersgrupper som leder till minskat socialt stöd och samstämmighet, minskat arbetsplatsengagemang, minskad arbetsnöjdhet, etc.

- Det är inte mycket känt om varför och när stigmatisering inträffar och vad de faktiska konsekvenserna är angående tidigt pensionsutträde.

- Mer kunskap behövs om hur man kan kommunicerar skillnader i kapacitet mellan yngre och äldre arbetstagare på ett mer nyanserat sätt och utan att stigmatisera de äldre som grupp.

- Ökad kunskap om hur man effektiv kan nyttja olika arbetstagares kapacitet på arbetsplatsen är viktigt för att minska stigmatisering och ett led i detta kan exempelvis vara mentorskap, åldersblandad sammansättning av arbetsgrupper, etc. 


\section{Appendix}

Table 7: Working environment and health of older workers in Denmark

\begin{tabular}{|l|c|c|c|c|}
\hline Factor & Men (Blue collar) & Women (Blue collar) \\
\hline & $55-64$ yrs & $25-54$ yrs & $55-64$ yrs & $25-54$ yrs \\
\hline
\end{tabular}

Work hours

Fraction employed within the last year

Contractual working hours/week

Night work

Physical working environment

Occupational accident with sick leave within last 12 months

Physical strenuous work (scale 0-10)

$\%$ Lifting $1 / 4$ or more of working day

$\%$ Awkward postures $1 / 4$ or more of working day

$\%$ Hand lifted above shoulder $1 / 4$ or more of working day

$\%$ Monotonous movements $1 / 4$ or more of working day

$\%$ Vibrations $1 / 4$ or more of working day

$\%$ Loud noise $1 / 4$ or more of working day

Psychosocial working environment

$\%$ Conflicts more than once per month within last 12 months

Necessary to work at high speed (never <>always; 5 point)

Sufficient time for work tasks (always <>never; 5 point)

The workplace take particular considerations to employees with reduced work capacity (always <>never; 5 point)

$\%$ Subject to work harassment (bullying)at least monthly within last 12 months

$\%$ Subject to violence / threats within last 12 months

Help and support from nearest leader (always $<>$ never; 5 points)

Influence on how work is done (always <> never; 5 points)

Influence on when work is done (always $<>$ never; 5 points)

Work ability and health

Work ability ( $0<->10$ worst)

Vitality scale $\mathrm{SF}_{3} 6$ (o<->100 best)

Mental health scale $\mathrm{SF}_{3} 6$ (o<->100 best)

\begin{tabular}{|c|c|c|c|}
\hline $\begin{array}{r}5.9 \% / \\
8.7 \%\end{array}$ & $\begin{array}{r}11.9 \% / \\
12.0 \%\end{array}$ & $\begin{array}{r}4.2 \% / \\
4.1 \%\end{array}$ & $\begin{array}{r}12.1 \% / \\
13.0 \%\end{array}$ \\
\hline $39.2 / 3^{8.1}$ & $40.9 /$ & $34.9 / 32.2$ & 36.3 \\
\hline & 40.2 & & 34.7 \\
\hline $6.8 \%$ & $8.6 \%$ & $5.2 \%$ & $5.7 \%$ \\
\hline $11.7 \%$ & $12.6 \%$ & $3.7 \%$ & $6.1 \%$ \\
\hline $6.2 \%$ & $7.6 \%$ & $5.0 \%$ & $5.0 \%$ \\
\hline $9.5 \%$ & $13.1 \%$ & $5.2 \%$ & $9.5 \%$ \\
\hline 3.2 & 3.3 & 3.0 & 3.0 \\
\hline 4.8 & 5.4 & 5.2 & 5.6 \\
\hline $28.4 \%$ & $31.4 \%$ & $22.7 \%$ & $24.9 \%$ \\
\hline $52.0 \%$ & $62.4 \%$ & $51.7 \%$ & $61.9 \%$ \\
\hline $25.5 \%$ & $26.5 \%$ & $23.4 \%$ & $25.9 \%$ \\
\hline $46.6 \%$ & $51.3 \%$ & $50.1 \%$ & $54.9 \%$ \\
\hline $15.7 \%$ & $17.9 \%$ & $13.8 \%$ & $15.2 \%$ \\
\hline $30.2 \%$ & $39.1 \%$ & $33.2 \%$ & $42.6 \%$ \\
\hline $16.8 \%$ & $19.2 \%$ & $16.5 \%$ & $17.3 \%$ \\
\hline $30.2 \%$ & $37.8 \%$ & $53.5 \%$ & $56.8 \%$ \\
\hline $11.6 \%$ & $13.2 \%$ & $1.8 \%$ & $2.4 \%$ \\
\hline $22.8 \%$ & $27.6 \%$ & $5.8 \%$ & $9.7 \%$ \\
\hline $17.4 \%$ & $19.7 \%$ & $14.1 \%$ & $15.3 \%$ \\
\hline $28.4 \%$ & $38.5 \%$ & $20.4 \%$ & $27.9 \%$ \\
\hline $14.0 \%$ & $20.0 \%$ & $12.3 \%$ & $17.0 \%$ \\
\hline $49.8 \%$ & $61.1 \%$ & $43.7 \%$ & $52.7 \%$ \\
\hline 3.7 & 3.8 & 3.8 & 3.9 \\
\hline 2.4 & 2.2 & 2.3 & 2.1 \\
\hline 2.5 & 2.6 & 2.6 & 2.7 \\
\hline 3.7 & 3.5 & 3.7 & 3.6 \\
\hline 2.2 & 2.2 & 2.2 & 2.2 \\
\hline 2.3 & 2.3 & 2.2 & 2.3 \\
\hline $11.4 \%$ & $11.0 \%$ & $13.8 \%$ & $12.3 \%$ \\
\hline $14.5 \%$ & $16.1 \%$ & $15.7 \%$ & $14.5 \%$ \\
\hline $2.7 \% /$ & $3.1 \% /$ & $8.7 \% /$ & $8.7 \% /$ \\
\hline $5.4 \%$ & $5 \cdot 5 \%$ & $11.3 \%$ & $11.5 \%$ \\
\hline $1.2 \% /$ & $1.6 \% /$ & $2.2 \% /$ & $1.2 \%$ \\
\hline $3.1 \%$ & $3.4 \%$ & $0.8 \%$ & $1.7 \%$ \\
\hline 2.5 & 2.5 & 2.4 & 2.4 \\
\hline 2.5 & 2.6 & 2.5 & 2.5 \\
\hline 1.6 & 1.6 & 1.7 & 1.7 \\
\hline 1.7 & 1.7 & 1.8 & 1.9 \\
\hline 2.0 & 2.0 & 2.0 & 2.0 \\
\hline 2.1 & 2.2 & 2.1 & 2. \\
\hline 1.6 & 1.5 & 1.5 & 1. \\
\hline 1.9 & 1.7 & 2.0 & 1. \\
\hline 67.0 & 64.4 & 64.3 & 61.6 \\
\hline 83.8 & 62.7 & 81.6 & 59. \\
\hline 83.6 & 80.3 & 81.5 & 78. \\
\hline 83.8 & 80.3 & 81.6 & 77.6 \\
\hline
\end{tabular}


Table 8: Working environment and health of older workers in Sweden

\begin{tabular}{|c|c|c|}
\hline Factor & $\begin{array}{l}\text { All men / } \\
\text { Blue collar } \\
50-64 \text { yrs }\end{array}$ & $\begin{array}{r}\text { All women / } \\
\text { Blue collar } \\
50-64 \text { yrs }\end{array}$ \\
\hline \multicolumn{3}{|l|}{ Physical working environment } \\
\hline$\%$ Strenuous work to breath faster $1 / 4$ or more of working day & $38 \% / 62 \%$ & $9 \% / 18 \%$ \\
\hline$\%$ Lifting $>15 \mathrm{~kg}$ several times per day & $16 \% / 29 \%$ & $9 \% / 25 \%$ \\
\hline$\%$ Awkward postures $1 / 4$ or more of working day & $26 \% / 44 \%$ & $24 \% / 41 \%$ \\
\hline$\%$ Hand lifted $1 / 4$ or more of working day & $20 \% / 36 \%$ & $13 \% / 30 \%$ \\
\hline$\%$ Monotonous movements $1 / 4$ or more of working day & $31 \% / 46 \%$ & $31 \% / 38 \%$ \\
\hline Vibrations from hand-held tools & $12 \% / 22 \%$ & $2 \% / 5 \%$ \\
\hline Loud noise & $25 \% / 44 \%$ & $14 \% / 22 \%$ \\
\hline$\%$ Conflicts (not colleagues) within last 12 months & $31 \% / 22 \%$ & $32 \% / 31 \%$ \\
\hline$\%$ Subject to work harassment (bullying) within last 12 months & $8 \% / 8 \%$ & $9 \% / 9 \%$ \\
\hline$\%$ Subject to violence or threats within last 12 months & $9 \% / 10 \%$ & $18 \% / 25 \%$ \\
\hline Support and encouragement from leader (always $<>$ never 100 points) & $43 / 39$ & $43 / 28$ \\
\hline Influence on planning of own work (always <> never 100 points) & $22 / 38$ & $29 / 39$ \\
\hline$\%$ with influence (more than $1 / 2$ work hours) on work speed & $41 \% / 48 \%$ & $61 \% / 65 \%$ \\
\hline
\end{tabular}

Table 9: Working environment and health of older workers in Norway

\begin{tabular}{|l|r|r|} 
Factor & $\begin{array}{r}\text { All men / } \\
\text { Blue collar }\end{array}$ & $\begin{array}{r}\text { All women } / \\
\text { Blue collar }\end{array}$ \\
& $50-69$ yrs & $50-69$ yrs
\end{tabular}

Work hours

Contractual working hours/week

Shift work

$37.9 / 36.7 \quad 35.8 / 28.5$

Physical working environment

Occupational accident with sick leave within last 12 months

$\%$ Work so hard that have to breath faster $1 / 4$ or more of working day

$\%$ Lifting $>20 \mathrm{~kg} 5$ times or more per day

$\%$ Lifting in awkward positions $1 / 4$ or more of working day

$\%$ Hands lifted $1 / 4$ or more of working day

$\%$ Monotonous and repetitive hand-arm movements $1 / 4$ or more of working day

$\%$ Vibrations from hand-held tools more than $1 / 4$ of working day

$\%$ Loud noise more than $1 / 4$ of working day

$\%$ Conflicts (often or sometimes) with leader

Necessary to work at high speed (never < > always; 5 points)

Time to do work tasks properly (description fits very good <> very bad, 5 point)

$11 \% / 22 \% \quad 17 \% / 26 \%$

$\%$ responding that a disease or functional impairment limits the type of work that can be performed

$1.2 \% / 1.8 \%$

$13 \% / 24 \%$

$13 \% / 24 \%$

$9 \% / 20 \%$

$12 \% / 25 \%$

$42 \% / 48 \%$

$6 \% / 15 \%$

$9 \% / 21 \%$

$10 \% / 10 \%$

$\%$ Subject to bullying or unpleasant teasing from colleagues or superior at least monthly

$3.5 / 3.3$

$0.9 \% / 0.5 \%$

$10 \% / 19 \%$

$6 \% / 8 \%$

$12 \% / 20 \%$

$10 \% / 16 \%$

$44 \% / 52 \%$

$1 \% / 3 \%$

$7 \% / 10 \%$

$9 \% / 6 \%$

$3.7 / 3.3$

$3.74 / 3.83 \quad 3.57 / 3.90$

$51 \% / 60 \% \quad 59 \% / 58 \%$

$\%$ Subject to violence or threats within last 12 months

$2 \% / 4 \% \quad 2 \% / 1 \%$

$3 \% / 3 \% \quad 8 \% / 6 \%$

Support and help from nearest leader, when needed (never < > always; 5 points) $\quad 4.1 / 3.9 \quad 3.9 / 4.0$

Influence on how work is done (very high degree <> very low degree; 5 points) $\quad 2.0 / 2.2 \quad 2.3 / 2.4$

Determine the pace of work (very high degree $<>$ very low degree; 5 points) $\quad 2.2 / 2.2 \quad 2.6 / 2.4$ 
Table 10: Working environment and health of older workers in Iceland

Factor

Work hours

Percentage fullempolyed

$65 \% \quad 38 \%$

Percentage partly employed

$9 \%$

Physical working environment

Reported occupational accidents with sick leave/ requiring medical attention

$1,2 \% / 2.9 \%$

$1,0 \% / 1,5 \%$

Necessary to work at high speed (never <>always; 5 point)

2.8

Support and help from nearest leader, when needed (never < > always; 5 points) 
Nordic Council of Ministers

Nordens Hus

Ved Stranden 18

DK-1061 Copenhagen K

www.norden.org

\section{WORKING ENVIRONMENT AND WORK RETENTION}

The project shows that the working environment is rarely the sole cause of early retirement, but working environment factors may explain a large fraction of the transition to disability pension in particular.

Several working environment predictors of early retirement are welldocumented in the Nordic countries, but workplace policies and activities to retain older workers rarely aim to improve the working environment.

There may be great potentials in developing workplace interventions which combine prevention of working environment risk factors (e.g. risk factors for accidents, strenuous work/high physical work demands, insufficient recovery between work shifts, quantitative work demands, conflicts at work and bullying/harassment, and age discrimination) with increment of job satisfaction through increased control/influence, possibilities for development and recognition from management. 